\title{
DIREITO E MÉTODO: A CONTRIBUIÇÃO DE RONALD DWORKIN
}

DISSERTAÇÃO DE MESTRADO

ORIENTADOR: PROFESSOR TITULAR

JOSÉ EDUARDO CAMPOS DE OLIVEIRA FARIA

FACULDADE DE DIREITO DA UNIVERSIDADE DE SÃO PAULO 2013 


\section{DIREITO E MÉTODO: \\ A CONTRIBUIÇÃO DE RONALD DWORKIN}

DISSERTAÇÃO DE MESTRADO

Dissertação apresentada à Faculdade de Direito da Universidade de São Paulo como requisito parcial para a obtenção do título de Mestre junto ao Departamento de Filosofia e Teoria Geral do Direito.

ORIENTADOR: PROFESSOR TITULAR JOSÉ EDUARDO CAMPOS DE OLIVEIRA FARIA 
Nome: Reis, Luciana Silva.

Título: Direito e Método: A contribuição de Ronald Dworkin

Dissertação apresentada à Faculdade de Direito da Universidade de São Paulo como requisito parcial para a obtenção do título de Mestre junto ao Departamento de Filosofia e Teoria Geral do Direito.

Aprovado em:

\section{Banca Examinadora}

Prof. Dr. Instituição:

Julgamento: Assinatura:

Prof. Dr. Instituição:

Julgamento: Assinatura:

Prof. Dr. Instituição:

Julgamento: Assinatura: 
A única verdade com V maiúsculo é que quem decide como vai tentar ver as coisas são vocês mesmos. Essa, a meu ver, é a liberdade de uma educação autêntica, de aprender a ser bem ajustado: poder decidir conscientemente o que tem significado e o que não tem. Poder decidir o que venerar. Pois aqui está uma outra verdade. Nas trincheiras cotidianas de uma vida adulta, não existe isso de ateísmo. Não existe isso de não venerar. Todo mundo venera. Nossa única escolha é o que venerar. O grande truque é conseguir manter a verdade na superfície da consciência em nossas vidas cotidianas.

A verdade com $V$ maiúsculo diz respeito à vida antes da morte. Diz respeito ao valor real de uma verdadeira educação, que não tem nada a ver com notas e diplomas e tudo a ver com simples consciência - consciência daquilo que é tão real e essencial, que está tão escondido à luz do dia onde quer que se olhe que precisamos repetir para nós mesmos a todo momento: "Isto é água, isto é água”. É incrivelmente difícil fazer isso, ter uma vida consciente e adulta, dia após dia. E com isso mais um clichê se prova verdadeiro: a nossa educação leva mesmo a vida toda.

David Foster Wallace, "Isto é água" Em Ficando longe do fato de já estar meio que longe de tudo, tradução de Daniel Galera e Daniel Pelizzari 


\section{AGRADECIMENTOS}

Ao longo da minha trajetória acadêmica, tive a sorte de participar de vários grupos e instituições, nas quais pude vivenciar a academia como um empreendimento coletivo e, assim, muito mais interessante que uma trajetória solitária de busca pelo conhecimento.

O primeiro desses grupos foi o Programa de Educação Tutorial, então coordenado pelo professor José Eduardo Faria na Faculdade de Direito da USP, e ao qual me juntei no segundo ano. O PET foi, em vários sentidos, a minha faculdade, e por toda a experiência que pude ter aí não poderia ser mais grata ao professor Faria. A ele agradeço também pela generosa e paciente orientação acadêmica, que vem se prolongando desde os primeiros anos da faculdade e que culminou neste trabalho.

Ao professor Ronaldo Porto Macedo Junior, agradeço pelo constante apoio e diálogo desde o primeiro ano de faculdade, que se intensificou durante meu terceiro ano, quando ele me deu a oportunidade de conhecer a trabalhar na Escola de Direito da Fundação Getúlio Vargas. Esta foi, sem dúvida, uma segunda casa, onde encontrei uma comunidade acadêmica vibrante e amigos com os quais compartilhar angústias diversas. Agradeço ainda a Rafael Mafei Rabelo Queiroz, que me deu a oportunidade de voltar à Direito GV, dessa vez na pós-graduação. Ao professor Ronaldo Macedo, agradeço ainda pela participação e pelos valiosos comentários feitos durante minha banca de qualificação.

Agradeço também a Marcos Nobre, Ricardo Terra e José Rodrigo Rodriguez, pela oportunidade de participar do Núcleo de Direito e Democracia do Centro Brasileiro de Análise e Planejamento, cujos integrantes, sempre fontes inesgotáveis de aprendizado, me desafiam a pensar em novas perspectivas teóricas.

A Carlos Ari Sundfeld e Roberta Sundfeld, agradeço pela confiança nas diversas oportunidades em que pude colaborar com a Sociedade Brasileira de Direito Público, seja em aulas na Escola de Formação, seja em projetos de pesquisa coletivos.

Por fim, não poderia deixar de lembrar o meu atual ambiente de trabalho, a Procuradoria Regional Eleitoral em São Paulo, na qual tenho a sorte de trabalhar sob a chefia de dois Procuradores que são, antes de tudo, professores: André de Carvalho Ramos e Paulo Thadeu Gomes da Silva. Pela paciência durante o período final da dissertação e pela oportunidade constante de sempre aprender algo novo, sou muito grata. Agradeço 
ainda, imensamente, a todos os meus colegas de Procuradoria, cuja ajuda foi inestimável para atravessar o período difícil do final do prazo de entrega.

Agradeço o professor Jean-Paul Cabral Veiga da Rocha pelos comentários oferecidos na banca de qualificação.

Durante todos esses períodos e todas essas andanças, várias pessoas foram inestimáveis. Agradeço às minhas amigas e aos meus amigos, próximos ou distantes, que deram uma palavra de apoio em algum momento desta trajetória.

A Leonardo Rosa, agradeço pelo companheirismo de urso, por seu pequeno coração que aumenta, pela paciência, pelas conversas e pelo aprendizado. A Lucas Berthoud, agradeço pelas conversas, pelos smiles, pelos cartões de aniversário impagáveis, pelo Corinthians e por todos os textos sensacionais que ele ainda irá escrever. Registro essas pequenas coisas, porque elas foram essenciais em diferentes momentos desse mestrado.

A minha mãe, Eurica, meu pai, Luiz, minhas irmãs, Ana e Flávia, agradeço por todo o apoio durante todo este tempo que estou fora de casa. Cada um de vocês foi determinante, em diferentes períodos ao longo desses oito anos, para que eu me mantivesse focada em todos os objetivos que escolhi para mim. A meus pais, agradeço pela coragem de incentivar o conhecimento acima de qualquer bem material e pelo suporte incondicional em todos os meus projetos durante esses anos. A minhas irmãs, agradeço pela amizade e companheirismo que, apesar da distância, conseguimos cultivar.

A Yuri, enfim, poderia deixar de agradecer, por não ser exatamente gratidão nossa palavra. Nossa palavra - aprendizagem - abarca muito mais do que pode caber num simples gesto de agradecimento: não estamos e nunca estivemos obrigados um ao outro, mas sempre aprendendo um com o outro, em um empreendimento conjunto que confere valor e beleza a nossas vidas. Poderia deixar de agradecer, mas sinto que não devo: tudo o que você fez nos últimos meses merece muito mais que agradecimentos, e este é o mínimo que posso oferecer. O mínimo, e você apenas é quem conhece o máximo - porque é, na verdade, você quem me leva a esse limite e me faz querer, "sempre do meu jeito", superar todas as dificuldades que possam aparecer.

Muito obrigada a todos. 


\section{RESUMO}

A dissertação visa expor a tese de Ronald Dworkin que veio a ser conhecida como interpretativismo, segundo a qual o direito é uma "prática interpretativa". O objetivo principal é entender a contribuição metodológica que essa tese representa para o entendimento teórico do direito e qual seu argumento contra teorias do direito meramente descritivas. Para localizar a contribuição de Dworkin, são apresentadas, em primeiro lugar, as inovações metodológicas que surgem na obra seminal de Herbert Hart, O Conceito de Direito. A ideia chave que passa a ser discutida a partir dessa obra é a de ponto de vista interno. É considerada uma tese segundo a qual o próprio Hart teria "plantado as sementes" do interpretativismo. A teoria de Dworkin é então apresentada como uma teoria que, inicialmente, preocupa-se em entender a controvérsia no direito. Para isso, ela se vale de do argumento dos desacordos teóricos e do argumento relacionado do "ferrão semântico". Esses argumentos revelam uma característica política da prática jurídica que o positivismo analítico desconsiderou, ao tentar entender essa prática apenas por meio da abordagem da filosofia da linguagem. Ao interpretativismo é contraposto então o desafio proposto por uma teoria positivista contemporânea, a qual, ainda que não discorde do caráter normativo da prática, pretende defender o descritivismo na teoria. Por fim, como resposta a esse desafio, é apresentada a formulação mais recente do interpretativismo, a partir das obras de Dworkin Justiça de Toga e Justice for Hedgehogs. Nessas obras, estão formulados de maneira definitiva dois argumentos que são a chave para o entendimento da teoria interpretativa de Dworkin: o argumento sobre caráter controverso da prática jurídica e a indisponibilidade de explicações criteriais, e o argumento sobre a impossibilidade de realização de teorias "arquimedianas" (externas). A conclusão do trabalho é apresentada em forma de uma agenda de pesquisas para a teoria do direito e também para a sociologia jurídica, agenda esta que decorre da adoção da teoria interpretativista como a maneira mais adequada de enxergar a prática jurídica.

Palavras-chave: Ronald Dworkin, interpretativismo, debate Hart-Dworkin, teoria do direito descritiva, debate metodológico na teoria do direito. 


\section{ABSTRACT}

The dissertation aims to expose the Ronald Dworkin's thesis that has come to be known as interpretivism, according to which the law is an "interpretive practice". The main objective is to understand the methodological contribution that this thesis represents to the theoretical understanding of the law, and the argument it offers against merely descriptive theories of law. To locate the contribution of Dworkin's theory, the dissertation presents, first, the methodological innovations that arise in the seminal work of Herbert Hart, The Concept of Law. The key idea that starts being discussed is that of the internal point of view. It is considered an argument that Hart himself would have "planted the seeds" of Dworkin's interpretivism. Dworkin's theory is then presented as a theory that is initially concerned to understand the controversy in the practice of law. For that, it relies on the argument of theoretical disagreements and on the argument regarding the "semantic sting". These arguments reveal the political character of legal practice that was disregarded by analytical positivism due to its commitment to understand this practice only through the approach of the philosophy of language. Interpretivism is then contrasted to the challenge posed by a contemporary positivist theory, which agrees that the legal practice has normative character, but intends to defend descriptivism in theory. Finally, in response to this challenge, it is presented the latest formulation of interpretivism, bearing on recent Dworkin's books, Justice in Robes and Justice for Hedgehogs. In these works, two arguments that are key to the understanding of Dworkin's interpretive theory receive its final formulation: the argument about the controversial character of legal practice and the unavailability of criterial explanations, and the argument about the impossibility of "Archimedean" (external) theories. Following the adoption of interpretive theory as the most appropriate way of looking at legal practice, the study concludes in the form of a research agenda for the theory of law and to legal sociology.

Keywords: Ronald Dworkin, interpretivism, Hart-Dworkin debate, descriptive theory of law, methodological debate in legal theory. 


\section{Sumário}

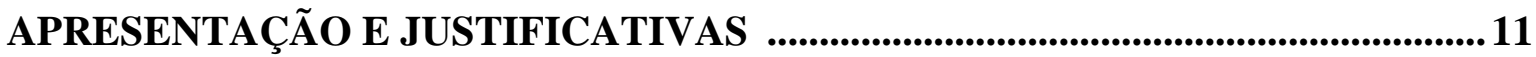

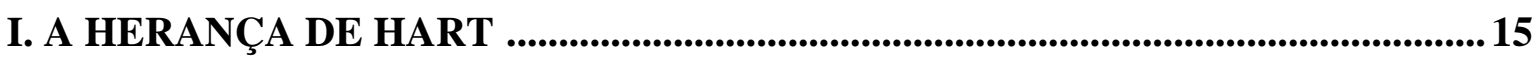

1. Da análise conceitual ao ponto de vista interno ................................................ 15

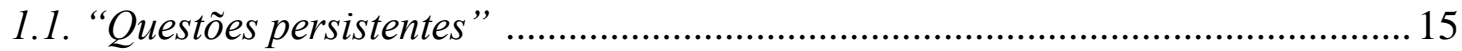

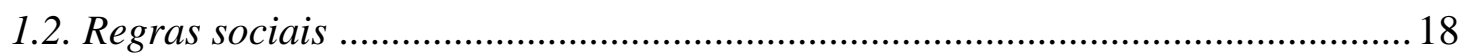

1.3. Das "questões persistentes" ao ponto de vista interno: análise conceitual e

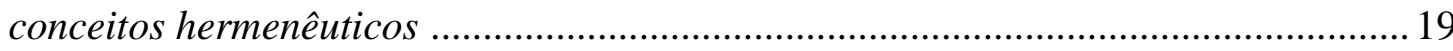

2. A herança de Hart: entendendo a "vida dupla" do direito ................................28

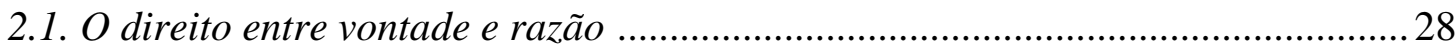

2.2. O ponto de vista interno como fonte de normatividade e o estatuto metodológico

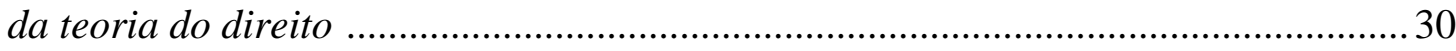

2.3. O "positivismo metodológico" de Hart e o "demônio interpretativista" ............. 33

II. O DIREITO COMO INTERPRETAÇÃO: PROPOSTAS E DESAFIO ................39

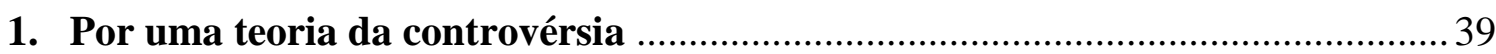

2. Desacordos teóricos e o argumento do ferrão semântico .................................... 45

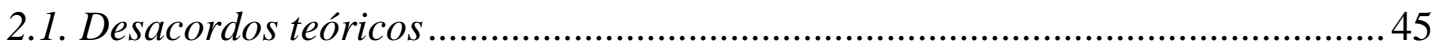

2.2. Positivismo hartiano, "visão do mero fato" e teorias semânticas .....................48

2.3. O ferrão semântico como uma "hipótese explicativa" e possíveis defesas do

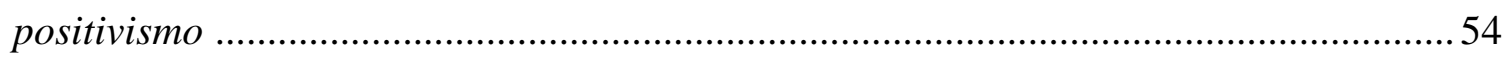

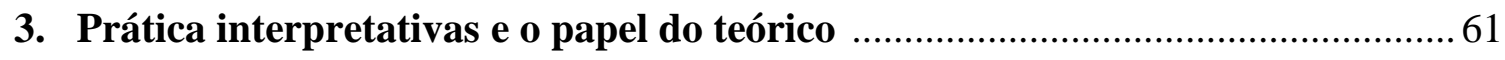

3.1. Práticas interpretativas: o que são e quando surgem .......................................62 62

3.2. A interpretação das práticas sociais e a indisponibilidade de teorias externas 68

3.2.1. Qual interpretação na prática interpretativa? 68

3.2.2. O teórico da prática: conceitos e concepções, paradigmas, adequação e

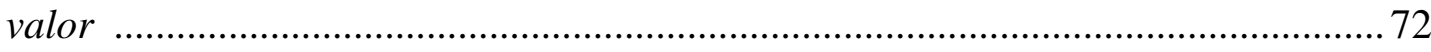

3.2.3. A interpretação no direito: o "prólogo silencioso" ...................................... 74

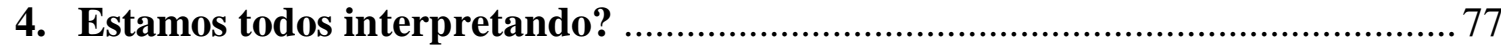

4.1. Natureza e conteúdo do direito: o desafio raziano .............................................. 77

4.1.1 Três maneiras de entender a natureza do direito ........................................ 77

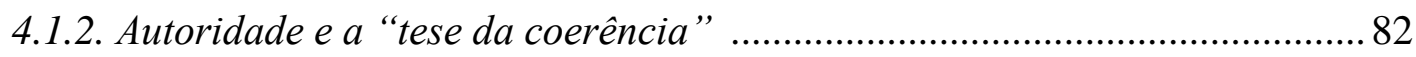

4.1.3. O método raziano para a teoria do direito .................................................... 85

4.2. A teoria do direito indiretamente avaliativa .................................................... 88

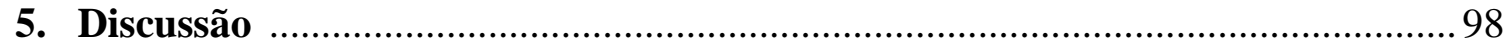




\section{INTERPRETATIVISMO NA PRÁTICA E NA TEORIA: FORMULAÇÕES}

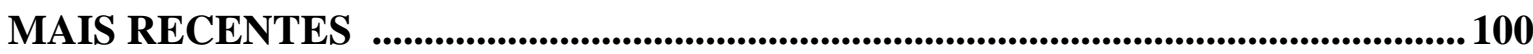

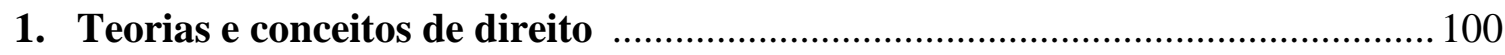

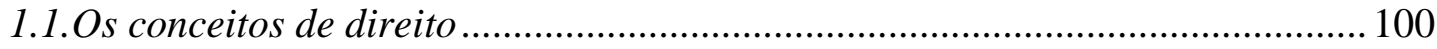

1.2. Reformulando o "ferrão semântico": os estágios da teoria do direito ............102

1.3. Confusões entre os conceitos e arquimedianos .............................................. 104

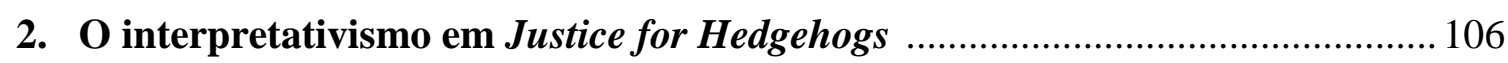

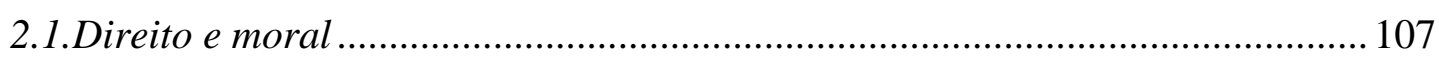

2.2. Uma abordagem abstrata da interpretação: verdade e reponsabilidade moral

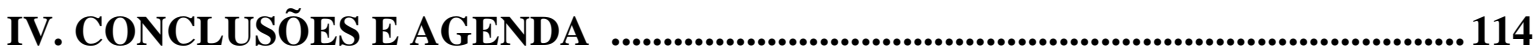

1. Levando o interpretativismo a sério: uma agenda de pesquisas ...................... 115

1.1. Interpretação, instituições e sociologia jurídica ............................................. 115

1.2. Conceitos doutrinários, dogmática jurídica e autoconsciência da interpretação

REFERÊNCIAS BIBLIOGRÁFICAS ......................................................................... 121 


\section{APRESENTAÇÃO E JUSTIFICATIVAS}

Quando se fala em trabalhos de metodologia, a desconfiança (para não dizer desprezo) é uma reação comum, dentro e fora da academia. A atitude desconfiada pensa que a metodologia é o campo ao qual se dedicam teóricos frustrados: seria a extrema dificuldade, ou mesmo a impossibilidade, de resolver problemas substantivos que nos levaria a acreditar na necessidade de discutir questões metodológicas. Estas são, assim, na melhor das hipóteses, um prelúdio desnecessário da verdadeira teoria; na pior, são subterfúgios, desvios do pensamento que se afasta das questões que importam.

Que o debate na teoria do direito contemporânea seja, em boa parte, um debate metodológico, parece representar, portanto, uma péssima contribuição a esta área (que já não desfruta das melhores famas em termos de "utilidade" ou "relevância" ).

O leitor espera, com razão, que a desconfiança seja afastada ao final desta dissertação. Mas não devemos desprezar desde já a atitude desconfiada: ela capta o sentido do "problema metodológico" ao afirmar que ele surge diante de dificuldades teóricas. Tais dificuldades revelam uma limitação na maneira pela qual a teoria é realizada, e exigem repensá-la em seus pressupostos mais básicos.

O direito é um objeto suficientemente complexo para fazer com que dificuldades desse tipo surjam a todo o momento. Este trabalho pretende abarcar uma dificuldade específica, que foi denominada, no capítulo que se segue, "a vida dupla" do direito. Tratase de uma ambiguidade do fenômeno jurídico: ele se apresenta ao mesmo tempo como um conjunto de instituições sociais organizadas em torno do poder de coerção, e como uma prática normativa que nos fornece razões para agir - o sentido das nossas ações está frequentemente voltado para questões jurídicas.

A teoria de H. L. A. Hart é o ponto de partida do trabalho por ter evidenciado essa dualidade, ao propor que a teoria do direito deve abarcar o ponto de vista interno, ou seja, o ponto de vista daqueles que agem tomando o direito como orientação para agir. A consideração do ponto de vista interno é a chamada virada hermenêutica da teoria do direito: trata-se da percepção de que uma descrição puramente externa da prática pode revelar, em termos de hábitos, as atitudes recorrentes daqueles que dela participam, mas não revelará a regra social propriamente criada por essa prática.

A proposta metodológica de Hart gerou inúmeros debates acerca do estatuto da própria teoria, que serão expostos no primeiro capítulo. Um dos debates, com o qual o primeiro capítulo é finalizado, sugere que a teoria hartiana pode ser vista como um 
"prelúdio" ao método interpretativo, ou interpretativismo, que é objeto central desta dissertação, e que foi proposto pelo mais notório discípulo de Hart, Ronald Dworkin.

O segundo capítulo é o coração da dissertação: nele exponho no que consiste o interpretativismo como um método de teoria do direito. Esse capítulo apresenta uma leitura da obra de Dworkin segundo a qual, em primeiro lugar, a noção do "direito como prática interpretativa" é a principal crítica oferecida pelo autor contra o positivismo jurídico e, em segundo lugar, essa crítica consiste em afirmar uma característica política da prática jurídica que o positivismo analítico desconsiderou ao tentar entender essa prática apenas por meio da abordagem analítica da filosofia da linguagem.

Nesse sentido, o mais notório dos argumentos dworkinianos, o do "ferrão semântico", argumento este frequentemente entendido como uma tese conceitual de filosofia da linguagem, é reapresentado à luz de sua força política, como apenas uma etapa do argumento mais abrangente acerca dos desacordos teóricos na prática jurídica.

O interpretativismo é então exposto como uma poderosa ferramenta crítica de entendimento do direito e da própria teoria jurídica. Ele propõe que a prática jurídica só pode ser adequadamente "vista" por meio de uma abordagem necessariamente avaliativa, que permite entendê-la como uma prática cuja característica fundamental é a controvérsia. Mais que uma caracterização da prática, no entanto, o interpretativismo é também uma maneira de entender a teoria como uma "prática em nível mais abstrato". Assim, ele propõe que qualquer teoria jurídica, se voltada a responder a questão sobre $o$ que é o direito - o que ele exige, proíbe, permite - estará engajada na prática, mesmo que esta não seja uma intenção consciente do teórico.

Ainda no segundo capítulo, apresento um desafio que positivistas contemporâneos formulam justamente contra este último aspecto do interpretativismo: o da exigência de que toda teoria do direito seja avaliativa. O positivista deseja manter devida distância das controversas questões políticas e morais que qualquer prática jurídica apresenta. Depois de Hart, não lhe é mais possível negar a normatividade da prática, então ele tenta negar a normatividade da teoria. Acredito que isso tenha sido feito de maneira mais acabada e explícita por Joseph Raz e seus seguidores, por isso é na versão destes autores que apresentarei esse desafio positivista.

O terceiro capítulo, por fim, traz a resposta dworkiniana a esse desafio, mas o principal propósito desta parte da dissertação é apresentar a formulação mais recente da tese interpretativista, que foi aperfeiçoada e extendida, respectivamente, em Justiça de Toga (DWORKIN, 2006b) e Justice for Hedgehogs (DWORKIN, 2011). Nesta última 
obra, Dworkin formula sua filosofia moral da maneira mais abrangente possível, conferindo à ideia de interpretação um caráter central: ela passa a ser vista, ao lado da ciência, como um dos grandes domínios do entendimento.

A resposta ao desafio positivista é apresentada, assim, a partir das formulações definitivas, presentes nestas últimas obras, dos dois argumentos que são a chave para o entendimento da teoria interpretativa de Dworkin: o argumento sobre caráter controverso da prática jurídica e a indisponibilidade de explicações criteriais, e o argumento sobre a impossibilidade de realização de teorias "arquimedianas" (externas).

Ao final da dissertação, espero que o leitor esteja convencido de que a "metodologia jurídica", no sentido que nos é fornecido pelos debates da teoria do direito, antes de ser um conjunto de diretrizes para fazer o direito, é uma autocompreensão poderosa do que já estamos fazendo quando nos engajamos na prática jurídica.

Assim, a conclusão do trabalho é apresentada em forma de uma agenda de pesquisas, para a teoria do direito e também para a sociologia jurídica, agenda esta que decorre da adoção da teoria interpretativista como a maneira mais adequada de enxergar a prática jurídica.

Apresentado o percurso do trabalho, cumpre fazer algumas considerações sobre a relevância do tema e do autor escolhido.

Quanto ao tema, trata-se de uma questão que está no centro das atuais preocupações da teoria do direito, a qual, a partir do debate Hart-Dworkin, tem sido cada vez mais permeada por questões metodológicas. Nesse contexto, a abordagem metodológica de Dworkin apresenta um departamento completamente novo na teoria do direito, pois ele recusa e coloca no centro de sua crítica os métodos da filosofia analítica, que, desde Hart, têm sido os métodos por excelência da teoria do direito.

Além dessa relevância no contexto dos debates da teoria do direito anglo-saxã, a abordagem do interpretativismo com vistas a esclarecimentos metodológicos é uma reflexão importante para questões mais práticas, inclusive na atual academia jurídica brasileira.

O fenômeno jurídico é hoje objeto central de estudo das ciências humanas e vem sendo analisado com especial atenção por estudiosos das mais diferentes disciplinas. Ao mesmo tempo em que começa a haver essa incorporação do Direito por outras ciências, a própria ideia de pesquisa jurídica passa a ser problematizada.

A noção de que a pesquisa jurídica, especialmente de cunho empírico, não foi privilegiada no estudo do direito no Brasil (FARIA \& CAMPILONGO, 1991, p. 43-44) é 
hoje uma ideia corrente. Há a percepção de que o direito permaneceu uma disciplina isolada das demais áreas das ciências humanas e não acompanhou o salto qualitativo dos últimos cinquenta anos das pesquisas nessa área (NOBRE, 2003, p. 147). Em outras palavras, a interdisciplinaridade crescente trouxe à tona um problema metodológico que até então pouco preocupava juristas: como tratar o Direito como um objeto de pesquisa, seja esta empírica ou teórica? Acredito que, para lidarmos com esse problema, que vai aos poucos ocupando um lugar central na academia jurídica atual, a contribuição de Dworkin para a metodologia jurídica é de muito interesse.

É claro que o interpretativismo não nos "ensina" como fazer pesquisa em direito, e nem é esta a intenção de Dworkin. Mas a maneira como a ideia do "direito como interpretação" se desenvolve na obra de Dworkin, especialmente com a formulação de diversos tipos de conceito de direito e diferentea formas de realizar teoria, fornece insights importantes para os juristas-pesquisadores. Esses insights são explorados na agenda de pesquisa apresentada ao final da dissertação.

Por fim, quanto ao autor escolhido, é inegável que se trata de um dos mais discutidos na teoria do direito contemporânea. No Brasil, a parte "substantiva" de sua teoria (especialmente DWORKIN, 1978; 1985; 1986; 1994), tem sido objeto de análises das mais diversas, principalmente nas áreas do direito constitucional, dos direitos humanos e da análise de jurisprudência (dentre outros, IKAWA, 2004; CHUEIRI \&SAMPAIO, 2009). Sua teoria da justiça e a defesa do igualitarismo liberal recebem igualmente atenção por parte da literatura (DALL'AGNOL, 2005; FURQUIM, 2010). O aspecto metodológico da teoria dworkiniana, no entanto, não tem sido objeto de grande atenção no Brasil, exceção feita à recentíssima obra de MACEDO JR. (2012).

Assim, esta dissertação fornece uma contribuição para essa área que ainda não foi objeto de muita literatura no Brasil. A pretensão do trabalho não é apenas mostrar a metodologia de Dworkin, como apresentar este aspecto como um dos mais instigantes e complexos de toda sua teoria. 


\section{A HERANÇA DE HART}

Neste capítulo, pretendo expor a complexidade teórica que norteou a teoria hartiana e como essa teoria, ao propor uma nova abordagem metodológica para a maneira como o direito vinha sendo analisado, pretendeu dar conta dessa complexidade. Assim, será possível entender em que pontos a abordagem de Ronald Dworkin é diferente e inovadora, apesar de, em certos sentidos, representar uma continuação da tradição hartiana.

\section{Da análise conceitual ao ponto de vista interno}

\section{1. "Questões persistentes",}

O Conceito de Direito (HART, 2005), obra seminal de Hart publicada em 1961, revela em seu próprio título um importante compromisso teórico do autor: o fenômeno jurídico será esclarecido por meio da análise do conceito de direito. Para entender quais as características desse tipo de análise, é importante retomar as questões propostas por Hart logo no início de sua investigação, pois são elas que nos dão o "mapa do caminho" a ser percorrido pelo autor.

O livro inicia com a exposição de certa perplexidade própria à teoria jurídica: esta julgou necessário esclarecer o que é o direito, em um “debate teórico infindável”, apesar da "aptidão com que a maior parte dos homens cita, com facilidade e confiança, exemplos de direito, se tal lhes for pedido" (Ibid., p. 6).

Se há conhecimento compartilhado acerca do termo, Hart indaga, "como é que a questão 'O que é o direito?' tem persistido e lhe têm sido dadas tantas respostas, tão variadas e extraordinárias?" (Ibid., p. 7). A proposta do autor para acessar essas perplexidades é diferirmos a resposta à grande questão - o que é o direito -, até que sejamos capazes de responder outra questão, esta sim passível de receber uma resposta de ordem geral: “Que mais querem saber e por que razão querem sabê-lo?” (IdIbid., p. 10, grifo acrescentado).

O sentido dessa proposta é identificar as "questões persistentes" que estão por trás das demandas de definição do termo. Segundo Hart, algumas noções, como a noção de

\footnotetext{
${ }^{1}$ Este é o título do primeiro capítulo de $O$ Conceito de Direito.
} 
obrigação e a noção de regra, sempre aparecem quando estamos nos perguntando sobre a natureza do direito.

As duas primeiras questões identificadas por Hart estão relacionadas à ideia de que, quando falamos do direito, estamos falando de algo cuja existência torna as condutas humanas obrigatórias em certo sentido. A primeira questão lembra que uma ameaça também traz obrigatoriedade às condutas e pergunta: em que o direito e a obrigação jurídica diferem de ordens baseadas em ameaças? A segunda questão traz à tona outro elemento que surge quando falamos em obrigatoriedade de condutas, a moral. Essa questão é mais complexa, trazendo indagações sobre em que pontos direito e moral podem se relacionar: Eles compartilham um vocabulário? O direito reproduz exigências morais fundamentais? É possível dizer que a justiça faz uma ligação entre os dois campos? (HART, 2005, p. 10-12). Uma terceira questão, por sua vez, está relacionada com a ideia de regra: "À primeira vista, poderia parecer que a afirmação de que um sistema jurídico consiste, pelo menos em geral, em regras, dificilmente podia ser posta em dúvida ou tida como difícil de compreender" (Ibid., p. 12-13). Mas aqui também não há um esclarecimento fácil, pois não temos uma definição imediata do conceito de "regra", não sabemos exatamente o que significa dizer que "regras existem", nem mesmo se elas existem, uma vez que juízes podem estar apenas fingindo quando dizem estar aplicando-as (Ibid., p. 13).

As questões recorrentes ${ }^{2}$ nos mostram, portanto, que a indagação sobre qual é o conceito de direito nos leva a outras indagações a ela relacionadas, de respostas igualmente obscuras. Utilizar métodos usuais e simples de definição de conceitos - o mais usual é definição "por gênero e diferença"3 - não nos ajuda. Esse método pode ser adequadamente usado para conceitos como "elefante" e "triângulo", porque tais conceitos possuem instâncias gerais: "animal mamífero da família Elephantidae, de grande porte e possuidor de tromba", "figura geométrica de três lados". Não há, entretanto, uma instância geral ("gênero") à qual se associa o direito e, mesmo que pudéssemos identificá-la (por exemplo, "fenômeno social pertencente à família geral de regras de comportamento"), ela não nos

\footnotetext{
${ }^{2}$ Nas palavras de Hart: "Aqui estão, pois, as três questões recorrentes: Como difere o direito de ordens baseadas em ameaças e como se relaciona com estas? Como difere a obrigação jurídica da obrigação moral e como está relacionada com esta? O que são regras e em que medida é o direito uma questão de regras?" (HART, 2005, p. 18).

${ }^{3}$ Hart já havia elaborado a crítica a esse tipo de definição em "Definition and Theory in Jurisprudence" (HART, 1983). Para uma crítica à ideia deste texto, ver HACKER (1969).
} 
daria meios de elucidação, pois a própria instância geral nos remete a elementos obscuros, o que não ocorre quando conceituamos elefante e triângulo (HART, 2005, p. 19-20).

Além disso, duas outras circunstâncias, relacionadas às características da linguagem de maneira geral ${ }^{4}$, e não só às peculiaridades da palavra direito, revelam a dificuldade da busca por suas definições. A primeira diz respeito ao fato de que o uso comum, ou mesmo técnico, dos termos linguísticos é "aberto", "na medida em que não proíbe a extensão do termo a casos em que apenas algumas das características normalmente concomitantes estão presentes" (Ibid., p. 20). Esses casos são os chamados "casos de fronteira", nos quais os termos podem ser usados, ainda que não ocorram todas as caraterísticas centrais dos fenômenos associados aos termos.

A segunda característica da linguagem que dificulta definições conceituais consiste no fato de que, mesmo "excluídos tais casos de fronteira, os vários casos de um termo geral estão frequentemente ligados entre si de maneira bastante diferente da postulada pela forma simples de definição" (Ibid., p. 20). Isso significa que, muitas vezes, não há uma instância geral ao qual se ligam as instâncias de ocorrência do conceito, por meio do compartilhamento de características comuns. Esse conjunto de características comuns não existe, por exemplo, quando os casos centrais dos conceitos são "elementos constituintes diferentes de certa atividade complexa" (Ibid., p. 20). ${ }^{5}$

Assim, quando nos detemos para apreciar a questão "O que é direito?", notamos que "nada de suficientemente conciso, susceptível de ser reconhecido como uma definição, lhe podia dar uma resposta satisfatória" (Ibid., p. 21). Mas apreciar a pergunta é importante, pois ao notarmos o que está por trás das indagações, ao percebermos a existência de indagações persistentes, podemos "isolar e caracterizar um conjunto central de elementos que formam uma parte comum da resposta a todas as três questões" (Ibid., p. 21, grifos acrescentados). É em busca da elucidação desses elementos que Hart irá construir sua teoria do direito.

\footnotetext{
${ }^{4}$ A distinção desses três tipos diversos de questão, sendo a primeira relacionada propriamente ao direito e as outras duas à linguagem em geral, é feita por STAVROPOULOS, 2001, p. 64-65.

${ }^{5}$ Essas duas questões referem-se a duas teses sobre a natureza da linguagem que são normalmente atribuídas ao filósofo Ludwig Wittgenstein e às quais Hart adere: a "textura aberta" da linguagem e a semelhança de família entre diferentes instâncias (STAVROPOULOS, 2001, p. 65). Sobre o conceito de textura aberta em Hart, ver ainda BIX, 1991.
} 


\subsection{Regras sociais}

Em Hart, a busca por esse "conjunto central de elementos" será direcionada ao esclarecimento das noções de obrigação (primeira e segunda questões) e regras (terceira questão), que passam a ser vistos como conceitos intimamente relacionados. O último tem precedência sobre o primeiro, pois é por meio do conceito de "regra social" que compreenderíamos a obrigação em sua forma jurídica.

Hart nota que, ao nos referirmos a uma situação em que alguém é coagido a entregar dinheiro para um assaltante armado, não dizemos que essa pessoa "teve a obrigação" de entregar o dinheiro; dizemos, mais propriamente, que a pessoa "foi obrigada". A diferença do uso das expressões mostra que a ideia de "ter uma obrigação" é independente, ao contrário de "ser obrigado", das crenças e motivos tidos por uma pessoa para tomar determinada ação. "Ser obrigado" é uma afirmação psicológica: revela que a pessoa considerou estar sob uma ameaça real, que a levou a tomar determinada atitude. "Ter uma obrigação", por outro lado, não é uma afirmação que possa ser justificada pelas crenças e motivos psicológicos de alguém, e nem estes são necessários à afirmação (HART, 2005, p. 92-93) ${ }^{6}$. O que há de diverso no segundo caso é a existência de uma regra social:

Para compreender a ideia geral de obrigação como um passo preliminar necessário para a sua compreensão na forma jurídica, temos de recorrer a uma situação social diversa que, diferentemente da situação do assaltante armado, inclui a existência de regras sociais: isso porque esta situação contribui de dois modos para o significado da afirmação de que uma pessoa tem uma obrigação. Em primeiro lugar, a existência de tais regras, que transformam certos tipos de comportamento em padrões, é o pano de fundo normal, embora não afirmado, ou o contexto adequado a tal afirmação, e, em segundo lugar, a função distintiva de tal afirmação consiste em aplicar tal regra a uma pessoa em particular, através da chamada de atenção para o facto de que o seu caso cai sob essa regra. Vimos no Capítulo IV que aparece coenvolvida na existência de quaisquer regras sociais uma combinação de conduta regular

\footnotetext{
${ }^{6}$ É importante notar que "ser obrigado" e "ter uma obrigação" não são proposições cuja aplicação está ligada de forma necessária a dois grupos distintos de ordens, com a primeira proposição envolvendo meras ameaças e a segunda envolvendo obrigações jurídicas (ou morais ou de qualquer outro tipo, uma vez que a distinção, de maneira geral, não está relacionada somente ao direito). Não há contradição em afirmar, por exemplo, que os paulistanos são obrigados a realizar periodicamente a inspeção veicular de seus automóveis, ainda que esta seja uma imposição estabelecida por lei. Tal afirmação pode ser realizada tanto do ponto de vista de alguém que não seja da cidade de São Paulo e, portanto, esteja apenas descrevendo uma conduta externa, quanto do ponto de vista de um paulistano fazendo referência a sua própria situação. Trata-se aqui da famosa distinção entre o ponto de vista interno e externo. Essa distinção e sua correspondência com as ideias de "ter obrigação" e "ser obrigado" serão adiante analisadas.
} 
com uma atitude distintiva para com essa conduta enquanto padrão (HART, 2005, p. 93, grifos acrescentados).

Como entender os dois elementos acima colocados? Em primeiro lugar, a passagem deixa claro que, onde existem regras sociais, as condutas são vistas como padrões (standards) de comportamento. Como tais, esses padrões representam mais que meras regularidades ou convergência de hábitos, fornecendo o "contexto adequado" para a afirmação de que existe uma obrigação, ou seja, tornando adequado fazer esse tipo de afirmação. Em segundo lugar, a existência da regra permite compreender a "função distintiva" da afirmação de que uma pessoa tem uma obrigação: essa afirmação é a aplicação da regra à conduta, o que revela que a regra tem a função crítica de qualificar condutas, "chamando a atenção" daqueles que as praticam para o fato de que se comportamento está qualificado. As regras sociais funcionam, portanto, como padrões de comportamento que fornecem o contexto adequado para a qualificação crítica de condutas enquanto estando ou não conforme obrigações.

A qualificação crítica é algo que só pode realizado a partir de um ponto de vista específico, que é aquele ponto de vista tido pelo participante da prática jurídica que toma a regra como padrão. Este é o ponto de vista interno, e entender porquê e como Hart pretendeu abarcá-lo em sua teoria é o que será visto no próximo tópico.

\subsection{Das “questões persistentes" ao ponto de vista interno: análise conceitual e conceitos hermenêuticos}

A brevíssima incursão por alguns aspectos da teoria de Hart acima realizada serve para ilustrar a forma pela qual o teórico abordou o fenômeno jurídico e é um ponto de partida para uma análise mais detida de sua metodologia. A questão que se coloca é: como Hart chegou à conclusão de que regras sociais fornecem a "chave para a ciência do direito"? Qual o percurso de sua teoria para chegar a este ponto?

Para responder a essa questão, devemos considerar, em um primeiro momento, por que Hart se recusa a dar uma definição precisa para "direito", argumentando que esse tipo de definição não estaria disponível e que, de qualquer maneira, não seria satisfatória. Como visto acima, para além de características da própria natureza da linguagem, o direito é um conceito difícil de elucidar por estar relacionado a outros conceitos eles mesmos obscuros, como coerção, obrigações e comportamento regulado por regras. 
Mas, mesmo diante dessas dificuldades, Hart nunca afirma a impossibilidade de se analisar o conceito de direito, como se as dificuldades mostrassem que, na verdade, não há um conjunto de situações comuns às quais o conceito se refere ${ }^{7}$. Na verdade, seu propósito é justamente tornar explícita a conexão entre as situações nas quais o conceito é usado. A ideia de que as respostas às "questões persistentes" compartilham um "conjunto central de elementos” (HART, 2005, p. 21), já analisada acima, vem justamente dessa intuição de que, onde quer que o direito ocorra, algumas características comuns serão notadas.

Esse modo de pensar é característico da atividade filosófica que se convencionou chamar "análise conceitual". Não pretendo aqui realizar uma abordagem compreensiva desse tipo de método, elencando suas virtudes e problemas enquanto atividade filosófica ${ }^{8}$, mas é importante entender a forma pela qual Hart se valeu da ideia de análise conceitual enquanto uma ferramenta para explicar o fenômeno jurídico.

O cerne dessa forma de pensar está no argumento de que um conceito denota um conjunto de situações diversas, mas esse conjunto é coerente ou estruturado de alguma forma. As instâncias do conceito não guardam entre si apenas uma relação superficial, de estarem todas associadas ao mesmo rótulo: ao contrário, existe uma estrutura interna pela qual podemos compreender a relação de diferentes instâncias com o conceito em si. O mais comum é supor que essa estrutura seja um conjunto de propriedades compartilhadas: é por possuírem um conjunto y de propriedades que $\mathrm{X}_{1}$ e $\mathrm{X}_{2}$ seriam instâncias do mesmo conceito X (FARREL, 2006, p. 997).

A análise conceitual geralmente procura identificar o entendimento comum, ou seja, o entendimento que as pessoas comuns, têm dessa estrutura interna dos conceitos. Por isso, diz-se que ela está preocupada com a articulação de uma "teoria popular" (folk theory), que é o mínimo entendimento teórico que qualquer falante deve possuir para se comunicar. Esse modo de proceder está baseado no argumento de que, para realmente nos comunicarmos, para que nossas proposições sejam sensatas, precisamos fazer referência ao “senso comum”, à maneira compartilhada pela qual entendemos as coisas.

\footnotetext{
${ }^{7}$ Esse é um argumento para sustentar que Hart se preocupou, sim, em fazer uma teoria semântica, ou seja, uma teoria do significado dos conceitos.

${ }^{8} \mathrm{O}$ mais citado defensor contemporâneo do uso filosófico da análise conceitual é JACKSON, Frank. From Metaphysics to Ethics: A Defence of Conceptual Analysis (Oxford, Clarendon Press 1998), uma referência usada por praticamente todos os comentadores no debate da filosofia do direito de tradição analítica. Mas a própria viabilidade da análise conceitual enquanto método, e seu interesse para a filosofia, são controversos (STAVROPOULOS, 2001, p. 69-70),
} 
Se eu me referir, por exemplo, a um exemplar de Os Miseráveis, com todos os seus milhares de páginas, como sendo um panfleto, dificilmente poderei me fazer compreender e provavelmente serei corrigida por alguém com maior competência linguística. Isso porque o que geralmente entendemos por panfleto é um texto curto, no máximo uma brochura. É claro que podemos discordar em casos-limite ( $O$ Manifesto Comunista, por exemplo, é um panfleto ou um livro?), mas isso não significa a inexistência de certo acordo sobre casos claros, o que me impede de fazer afirmações extravagantes sensatas ${ }^{9}$.

Para articular a estrutura interna das variadas instâncias de um conceito, a análise conceitual costuma proceder de duas formas características. Em primeiro lugar, ela busca entender de que maneira determinadas proposições são consideradas verdadeiras por proposições formuladas em vocabulários mais fundamentais. Essa afirmação pode parecer obscura, mas ela descreve exatamente o que viemos analisando até agora: a maneira pela qual Hart procede para elucidar o conceito de direito. O teórico procura, por meio dos termos "obrigação" e "regra", indicar as diferentes relações das instâncias do conceito de direito. Ele usa esse "vocabulário mais fundamental" para elaborar a estrutura interna do conceito: o que faz situações diversas serem todas instâncias do mesmo conceito de direito é a incidência dessas noções mais básicas ${ }^{10}$.

Em segundo lugar, a análise conceitual deve sobreviver ao "método dos casos possíveis" (JACKSON, 1998, p. 28 apud FARRELL, 2003, p. 998). Isso significa que a abordagem que se oferece do conceito deve abarcar as diversas situações nas quais

\footnotetext{
${ }^{9}$ Stavropoulos, valendo-se de um exemplo citado por Jackson (v. nota anterior), expões o argumento da seguinte forma: "It seems natural to suppose that conceptual analysis aims at articulating the existing, common understanding of the terms whose extension constitutes the field of inquiry. The argument behind that supposition is that, unless I mean by 'belief' what everyone else does, my substantive claim will miss its target It is not interesting, and perhaps not even sensible, the argument goes. to say that beliefs as

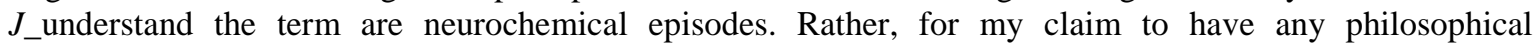
importance it must be the case that beliefs in the sense common to all thinkers are what I say they are" (STAVROPOULOS, 2001, p. 70, grifo no original). Formulado dessa maneira, o argumento parece direcionado a excluir a possibilidade de realizar teorias contra-intuitivas. Mas não creio que o comprometimento da análise conceitual com a "teoria popular" tenha essa decorrência. É possível que a análise conceitual revele que alguns usos intuitivos do termo não estão abarcados na maneira compartilhada pelo qual o termo é compreendido. Ainda sobre o comprometimento da análise conceitual com a articulação da "teoria popular", ver FARRELL, 2001, p. 997.

${ }^{10}$ As duas características são atribuídas por Jackson à análise conceitual. Farrell expõe a primeira da seguinte forma: "(i) Conceptual analysis is "the very business of addressing when and whether a story told in one ocabulary is made true by one told in some allegedly more fundamental vocabulary.' [...] The first of these features flows directly from my discussion of the nature of concepts. The description in the more fundamental vocabular indicates the relationship between different situations covered by the concept X, the structure that underlies the concept. [...] In general, conceptual analysis of $\mathrm{X}$ is an attempt to provides theory about what "makes" something an X, by breaking the concept down into its more fundamental characteristics." (FARRELL, 2001, p. 998).
} 
entendemos que o conceito se aplica. Trata-se de um apelo às nossas intuições mais básicas sobre os conceitos e suas aplicações: uma explicação conceitual deve fazer jus à forma pela qual usamos os conceitos para nos referirmos a diferentes casos. ${ }^{11}$ Hart usa exatamente essa estratégia para criticar a teoria do comando de Austin, argumentando que, em um sistema jurídico hipotético no qual Rex I é soberano, a continuidade do sistema, com a sucessão de Rex II no poder, não poderia ser explicada pela ideia de direito como um conjunto de ameaças regularmente obedecidas (HART, 2005, p. 60-64). Ao nos confrontarmos com esse exemplo, percebemos que a continuidade do poder de criação do direito é parte de uma prática mais complexa de aceitação de uma regra.

As duas formas de proceder da análise conceitual são complementares: a primeira busca articular a "estrutura interna" que une diversas instâncias em um único conceito, a segunda testa essa articulação em face das nossas intuições mais concretas sobre o uso dos conceitos. Como se nota, o método se vale tanto de uma investigação a priori quanto de uma abordagem a posteriori, que considera os usos do conceito na prática.

Isso traz dúvidas sobre as ambições da análise conceitual: o que ela pretende revelar é uma verdade necessária, ou apenas verdades sobre os conceitos? Em outras palavras, o que a análise conceitual revela é uma descrição do mundo, ou meramente do uso do conceito?

Essa questão permite distinguir dois tipos de análise: a modesta e a ambiciosa. Enquanto a primeira se propõe apenas a descrever usos de conceitos, a segunda quer revelar verdades "mais profundas" sobre o mundo. A análise conceitual ambiciosa, "por dar um lugar muito grande às intuições sobre possibilidades na determinação de como é o mundo" (JACKSON, 1998, p. 43-44 apud FARRELL, 2006, p. 999), é vista com desconfiança, e geralmente o defensor desse método o defende apenas em sua forma modesta $^{12}$.

\footnotetext{
11 “(ii) Conceptual analysis must "survive the method of possible cases": the methodology applied should produce an account of the concept that squares with our clear intuitions about the concept. [...]

The second feature of conceptual analysis that Jackson describes is na inevitable consequence of Jackson's own definition of a concept. The concept X, according to Jackson, is the set of possible situations covered by the term. Any account of the concept $\mathrm{X}$ should therefore accommodate our understanding as to which situations the term applies, at least when that understanding is fairly certain or reliable. Our understanding of the appropriate application of words is determined, in the context of conceptual analysis, by recourse to our intuitions." (FARRELL, Hart's, p. 998). Sobre a importância das nossas intuições para a análise conceitual, ver RODRIGUEZ-BLANCO, Veronica. A defence of Hart's, especialmente p. 112.

${ }^{12}$ Analisar conceitos e distinguir verdades necessárias em oposição a verdades empíricas é um procedimento antigo na filosofia. A distinção kantiana entre proposições analíticas (a priori) e sintéticas (a posteriori), afirma que, nas primeiras, a conexão do predicado com o sujeito se dá por meio de uma relação de identidade (e. g., "Todos os corpos são extensos"), na qual não é necessário ir além do conceito relacionado ao sujeito
} 
Este tipo de análise poderia ser criticado por ser, afinal, muito modesto: se não pretende fazer afirmações sobre a natureza das coisas, então qual seria seu interesse ou valor? Uma análise modesta está perigosamente próxima à realização de lexicografia e seus resultados poderiam não ser tão diferentes de um mero dicionário. Uma possível resposta é que, para a investigação metafísica, a análise dos conceitos, tendo por resultado uma abordagem geral sobre o seu sentido, é um trabalho preliminar e essencial, pois ela identifica o alvo da investigação metafísica ${ }^{13}$. Essa resposta, entretanto, não avança muito em atribuir à análise conceitual um sentido mais complexo que o da atividade lexicográfica.

Um segundo tipo de resposta à crítica busca mostrar que, para certos tipos de conceitos, a análise conceitual é "ao mesmo tempo inevitável e não trivial” (FARRELL, 2006, p. 1002). Conceitos de "tipo natural”, tais como elefante e água, parecem não requerer nenhuma forma de análise conceitual, nem mesmo do tipo modesto, pois, qualquer que seja o uso feito desses conceitos, ele sempre irá seguir os usos científicos, que identificam as instâncias corretas de forma completamente independente do uso corriqueiro que fazemos das palavras. ${ }^{14}$ Conceitos hermenêuticos ${ }^{15}$, por outro lado, não podem ser acessados da mesma maneira. Estes são conceitos que usamos para entendermos a nós mesmos e a nossas práticas e, assim, as diferentes instâncias que se relacionam ao conceito só podem ser definidas por seu uso. Em outras palavras,

A extensão de um conceito hermenêutico é, por definição, determinada pelo papel que ele possui na maneira pela qual tornamos nós mesmos e nossas práticas inteligíveis. [...] A metodologia emprega na análise conceitual modesta, pela qual a extensão do conceito é fixada por seu uso, seria a única forma apropriada de determinar a extensão de um conceito hermenêutico.

para encontrar o predicado - este é parte do sujeito. Uma crítica direcionada à análise conceitual nos anos 60 e 70 do século XX afirmou a ilegitimidade do método por ele estar baseado nessa distinção. Nesse sentido, LEITER, 2007 e RODRIGUEZ-BLANCO, 2003.

13 " [T] $]$ he questions we ask when we do metaphysics are framed in a language, and thus we need to attend to what the users of the language mean by the words they employ to ask their questions. When bounty hunters go searching, they are searching for a person and not a handbill. But they will not get very far if they fail to attend to the representational properties of the handbill on the wanted person. These properties give them their target, or, if you like, define the subject of their search." (JACKSON, p. 30 apud FARRELL, p. 1000). É nesse sentido que a análise conceitual é vista tradicionalmente como o "prólogo à metafísica" (STAVROPOULOS, 2001, p. 69)

${ }^{14}$ Poderia se pensar, por exemplo, que já se chegou a considerar que baleias eram peixes muito grandes. No entanto, uma vez que a ciência esclarece que baleias são mamíferos, o uso do conceito de peixe para designálas não está mais disponível.

${ }^{15}$ Estou usando aqui a terminologia adotada por Ian Farrell, que é quem formula, da maneira como exposto no texto, o argumento sobre a não trivialidade da análise conceitual para certos tipos de conceito. O que são conceitos hermenêuticos, se é que existe um único gênero desse conceito, é algo que ficará mais claro abaixo. 
Que outra autoridade pode existir para a extensão de um conceito hermenêutico se não a maneira pela qual ele é usado e entendido ${ }^{16}$

Assim, longe de ser trivial, a análise conceitual, tal como acima descrita, é o procedimento normal de entendimento de conceitos hermenêuticos. É dessa maneira que a análise do conceito de direito feita por Hart pode ser defendida contra a crítica de que seria uma atividade trivial ou desimportante.

De outro lado, a questão sobre o tipo de análise conceitual feito por Hart, se ele teria realmente se limitado à forma modesta ou se teria pretendido revelar "algo mais", é motivo de debate na literatura ${ }^{17}$. Como visto, o estudo dos conceitos pode ser feito de forma ambiciosa com vistas a revelar a própria natureza das coisas, e não meramente como um esclarecimento da maneira pela qual usamos os termos. Mas, no caso de Hart, mesmo aqueles que defendem que ele teria realizado uma análise ambiciosa não supõem que sua teoria tenha a pretensão revelar a natureza objetiva do mundo. A análise conceitual, em Hart, seria ambiciosa por assumir que o mero uso determina o entendimento correto dos conceitos (STAVROPOULOS, 2001, p. 73). Essa será uma questão relevante para entender a crítica de Ronald Dworkin que ficou conhecida como "ferrão semântico", e se ela foi ou não bem sucedida. Antes, no entanto, será preciso fazer alguns esclarecimentos adicionais sobre a metodologia hartiana.

Foi dito acima que, mesmo que seja possível atribuir, em algum sentido, uma análise conceitual ambiciosa a Hart, não seria o caso de dizer que a teoria hartiana pretendeu revelar a natureza do mundo como ele é. Para entender essa afirmação, é necessário analisar a maneira pela qual Hart pretendeu acessar o significado dos conceitos hermenêuticos.

Ao invocar o exemplo de Rex I e Rex II para elucidar o que faria possível a continuidade do poder de criar direito, Hart rejeita a proposta segundo a qual tal situação poderia ser explicada por um hábito de obediência. Isso porque, na situação em que ocorre

\footnotetext{
${ }^{16}$ Tradução livre de "The extension of a hermeneutic concept, by definition, is determined by the role it plays in how we make ourselves and our practices intelligible. [...] The methodology employed in modest conceptual analysis, whereby the extension of the concept is fixed by its usage, would seem to be the only appropriate means of determining the extension of a hermeneutic concept. What other authority could there be for the extension of a hermeneutic concept other than the way it is used and understood? Hermeneutic concepts are very different creatures than natural kind concepts such as fish and whales, or space and time." (FARRELL, 2006, p. 1002).

${ }^{17}$ O argumento elaborado por STAVROPOULOS (2001) segundo o qual Hart teria se comprometido com uma análise conceitual ambiciosa, que o levaria a adotar uma teoria semântica criterial, é diretamente refutado por RODRIGUEZ-BLANCO (2003). FARRELL (2006) também defende que Hart se limitou à análise conceitual modesta, mas seu argumento não é incompatível com o de STAVROPOULOS.
} 
a sucessão, a obediência habitual não explica como o novo legislador pode ter direito a suceder o anterior no poder de fazer leis. Além disso, o fato de a obediência ter sido praticada até então não torna provável, nem autoriza presumir, que as ordens do novo legislador serão obedecidas.

Para que haja um tal direito e uma tal presunção no momento da sucessão, deve ter havido algures na sociedade, durante o reinado do anterior legislador, uma prática social geral mais complexa do que a que pode ser descrita em termos de hábito de obediência; deve ter havido a aceitação de um regra, segundo a qual o novo legislador tem direito à sucessão (HART, 2005, p. 64).

Ao introduzir o conceito de regra para explicar a continuidade de um sistema jurídico, Hart chama atenção para uma diferença crucial entre hábitos e regras: ainda que em ambos os casos possamos verificar a existência de comportamentos regulares e uniformes, as regras têm um "aspecto interno" ausente no mero hábito. Tal aspecto manifesta-se na "atitude crítica reflexiva" que quem segue uma regra adota, ao tomar o comportamento conforme a regra não só como uma regularidade, mas como um padrão (standard) para todos os que participam da mesma prática de seguimento de regras (HART, 2005, p. 65-66).

Qualquer abordagem do conceito deve ser capaz, portanto, de "capturar" o aspecto interno. Dissemos acima que os conceitos hermenêuticos têm sua extensão fixada por seu uso. Assim, poderia se supor que a tarefa de análise desses conceitos consistiria em reunir as diferentes ocorrências destes, de acordo com a maneira pela qual são usados. Isso, no entanto, é impossível. Sem compreender a intensão de uso do conceito, o teórico não conseguirá captar sua extensão. A intensão ${ }^{18}$ é, em oposição à referência ou extensão, aquilo que identifica o sentido do conceito; ela só pode ser percebida do ponto de vista daquele que pratica a atividade conceitual. Este é o ponto de vista interno, que deve ser levado em consideração por qualquer teórico que pretenda compreender a atividade conceitual. Como esta é uma atividade completamente intencional ${ }^{19}$, então apenas de uma perspectiva interna, da nossa própria perspectiva, é possível compreendê-la: “a melhor

\footnotetext{
18 Como nos informa o Grande Dicionário Houaiss da Língua Portuguesa, as palavras "intenção" e "intensão" têm a mesma raiz etimológica, mas cada forma especializou seu sentido.

${ }^{19}$ A descrição objetiva de todas as situações em que pensamos haver direitos, por exemplo, não implica o entendimento do que seja o próprio direito. Isso porque este entendimento não está na extensão em que conceito é usado (assim como está o entendimento de conceitos naturais, como elefantes, que têm correspondências com objetos físicos), mas na intensão com que fazemos tal uso. É por isso que se diz ser a atividade conceitual uma atividade intencional.
} 
maneira de compreender nossa atividade conceitual é tomar o sentido, ou seja, retornar a nossa perspectiva" (MICHELON JR, 2004, p. 122).

É importante notar que abarcar o ponto de vista interno não significa, para Hart, fazer a teoria a partir desse ponto de vista. Isso porque o ponto de vista externo comporta tanto afirmações de quem "contenta-se apenas com a anotação das regularidades de comportamentos observáveis" quanto afirmações do observador que, "sem ele próprio aceitar as regras", afirma que "o grupo aceita as regras e pode assim referir-se do exterior ao modo pelo qual eles estão afectados por elas" (HART, 2005, p. 99).

Hart pretende, portanto, conhecer os enunciados internos, mas não endossá-los. A tese de que os enunciados internos possuem um conteúdo cognitivo depende, como observa Claudio Michelon, da distinção entre hábitos e regras, central na obra de Hart: se não fosse possível dizer que uma regra é mais do que mero hábito de comportamento, então não seria possível diferenciar logicamente enunciados externos (os quais descrevem regularidades de comportamento) de enunciados internos. O ponto fundamental é que enunciados internos e externos referem-se a diferentes tipos de fato: aqueles descrevem fatos institucionais, enquanto estes se ocupam de fatos "brutos". Os fatos institucionais dependem da existência de regras constitutivas, as quais criam a possibilidade lógica de um comportamento (a votação de uma lei, por exemplo, é, em certo sentido, um fato institucional) (MICHELON JR, 2004, p. 36).

Para se admitir a existência de fatos institucionais (o que equivale dizer, para admitir a existência objetiva de regras sociais), é preciso abandonar uma concepção empirista da realidade (e a concepção "absoluta" de objetividade dela derivada) e assumir que a "análise do nosso comportamento lingüístico pode levar a uma conclusão sobre a existência de algo". Nesse caso, dizer que existe uma regra significa dizer que ela é "utilizada como padrão de avaliação das ações humanas" (Ibid.,, p. 160-161). Ou seja, para uma regra, existir é o mesmo que ser usada.

Para os fins desta dissertação, não é necessário o aprofundamento da discussão sobre o conceito de objetividade tal como problematizado por Michelon. Basta apontar que a análise de conceitos hermenêuticos que não abarca a dimensão interna das regras, ao negligenciar esse relevante aspecto do objeto que pretende descrever, apresenta um sério déficit descritivo. Em outras palavras, a dimensão interna não se refere, como poderia pensar um realista, a meros estados mentais que, como fenômenos meramente subjetivos, poderiam ser desconsiderados pelo cientista; ao contrário, a consideração de regras no seu aspecto interno é algo que se manifesta objetivamente no mundo. 
A possibilidade de cognição dos enunciados internos de forma objetiva, que foi estabelecida por Hart com a diferenciação entre os dois pontos de vista, é a chamada virada hermenêutica da teoria do direito ${ }^{20}$. A teoria hartiana inova em relação à teoria do direito precedente ao afirmar não só que é possível realizar descrições verdadeiras do direito a partir do ponto de vista dos sujeitos; na verdade, abarcar esse ponto de vista é necessário para a realização de uma correta descrição do direito enquanto prática que se manifesta em regras sociais (MACEDO JR., p. 61 e 86-87) ${ }^{21}$.

Ao estabelecer a necessidade de cognição dos enunciados internos para corretamente descrever o direito, Hart estabelece a ideia de que o fenômeno jurídico é uma prática intencional. "A intencionalidade, diferentemente de uma causalidade mecânica verificável no mundo físico, envolve pensamento e deliberação e, portanto, propósito." (Ibid.., p. 89).

Assim, na visão hartiana, é preciso abarcar as razões envolvidas na prática, que se colocam, para os seus participantes, como guias de conduta:

O que o ponto de vista externo, que se limita a regularidades de comportamento, não pode reproduzir é o modo pelo qual as regras funcionam como regras relativamente às vidas daqueles que são normalmente a maioria da sociedade. Estes são os funcionários, os juristas ou as pessoas particulares que as usam, em situações sucessivas, como guias de conduta da vida social, como base para pretensões, pedidos, confissões, críticas ou castigos, nomeadamente em todas as circunstâncias negociais familiares da vida, de harmonia com as regras. Para eles, a violação da regra não é apenas uma base para predição de que se seguirá uma reacção hostil, mas

\footnotetext{
20 'Hart's approach, with its emphasis on the internal aspect of rules and of law, is 'hermeneutic' in the sense that it tries to understand a practice in a way that takes into account the way the practice is perceived by its participants" (BIX, 1999, p. 176). A ideia de que Hart ofereceu sua teoria de um "ponto de vista hermenêutico", que seria o ponto de vista externo "não extremo", é desenvolvida também por MACCORMICK (2008).

${ }^{21}$ A comparação da teoria de Hart com as teorias do direito precedentes é muito interessante para mostrar a ruptura promovida pela teoria hartiana com teorias fisicalistas e comprometidas com uma concepção absoluta de objetividade. Ainda que este seja um tema obviamente relacionado às questões tratadas na dissertação, não o discuto de forma mais extensa, pois o objeto deste estudo reside muito mais no caminho aberto por Hart e sua suscetibilidade às críticas de Dworkin do que na ruptura apresentada pela teoria hartiana. Sobre este tema, ver MACEDO JR, 2012, p. 46 e ss e BIX, 1999, p. 168-171. A discussão sobre a teoria do direito de Hans KELSEN (1999) é especialmente interessante. Kelsen deu um passo em direção à nova concepção de objetividade, ao reconhecer que esta, no fenômeno jurídico, depende em parte de um ato de vontade: descrever fenômenos naturais como jurídicos é uma atitude deliberada do sujeito. É por isso que se diz que a norma fundamental é um "pressuposto gnosiológico" do sistema: ela é um esquema de cognição. Kelsen, no entanto, não deixa de se comprometer com o fisicalismo, pois, para evitar a possibilidade de sistemas jurídicos "subjetivos", nos quais o próprio conteúdo da norma fundamental seria determinado pelo sujeito cognoscente, ele afirma ser necessário um "mínimo de eficácia” para que se diga que o sistema jurídico é válido, condicionando, assim, a objetividade jurídica de maneira geral à existência desse fato (MACEDO JR., 2012, p. 60).
} 
uma razão para a hostilidade (Hart, 2005, p. 100, grifo no original $^{22}$ ).

\section{A herança de Hart: entendendo a "vida dupla" do direito}

Qual a importância de abarcar na teoria as razões da prática jurídica? Neste tópico, pretendo argumentar que a "virada hermenêutica" promovida por Hart na teoria do direito fixou-se como ponto de partida para as discussões que se seguiram, por apresentar, na distinção entre ponto de vista interno e ponto de vista externo, a chave para o entendimento de uma característica do fenômeno jurídico que se constitui no maior desafio para qualquer teoria do ou sobre o direito: que este se manifesta por atos de vontade que constituem um sistema social ao mesmo tempo em que constitui uma prática que fornece razões para agir.

\subsection{O direito entre vontade e razão}

No pensamento moral, político e teológico, são comuns dois tipos de argumento. O primeiro afirma que atos de vontade que resultam das escolhas de indivíduos ou instituições podem ter incidência normativa, independentemente do valor moral dessas escolhas (por exemplo, a ordem emitida por um soberano ou a assinatura de um contrato). O segundo argumento, por outro lado, enfatiza que podemos fazer avaliações baseadas em razões, que revelam o mérito ou demérito de ações, interações ou instituições, independentemente de estas razões terem sido ou não escolhidas (ou mesmo apreciadas) por aqueles que praticam as ações ou compõem as instituições (BIX ${ }^{23}, 2008$, p. 210-211). O segundo argumento parece ter uma "nota transcendental": afirma que algo além das próprias ações, interações e instituições deve fornecer os fundamentos de entendimento e correção desses fenômenos ${ }^{24}$.

\footnotetext{
${ }^{22}$ Como nota John Finnis, "'Reason' is italicized more than any other noun in the book; it signifies practical reasons, the propositional element in thoughts of the form appropriate to guiding deliberation and eventual (possible) action." (FINNIS, 2007, p. 3, grifos acrescentados).

${ }^{23}$ Brian Bix tem diversas obras em que discute as questões metodológicas da teoria do direito a partir das implicações dessa dualidade, assim, os argumentos desse tópico são largamente baseados em suas reflexões.

${ }^{24}$ Em relação à característica transcendental do segundo argumento, é interessante lembrar que própria distinção entre vontade e razão surgiu na tradição do direito natural e, assim, é possível pensar também em argumentos de vontade que se fundamentam de maneira externa à prática, recorrendo, por exemplo, à vontade divina. Trata-se da distinção entre racionalistas e voluntaristas no direito natural (BIX, 2008, p. 210211). Mas, com a laicização do pensamento e a crescente indisponibilidade de argumentos baseados na existência de deus ou outro ser superior, a "fundamentação transcendental" ficou mesmo reservada aos "argumentos de razão".
} 
Quaisquer que sejam seus desenvolvimentos teóricos, a distinção tem relevância inegável para a prática jurídica, que envolve tanto "escolhas e declaração quanto dedução e análise abstrata" (Ibid., p. 216). O "lado vontade" do direito pode ser visto na importância dada a autoridade, convenções e decisões para caracterizar o fenômeno jurídico. Já o "lado razão" manifesta-se nas exigências de consistência feitas pelos que participam da prática jurídica: as normas devem ser consistentes entre si (coerentes) e também consistentes, ou de alguma forma derivadas, da verdade moral (BIX, 2008, p. 216). O direito, portanto, tem uma "vida dupla": ele possui uma estrutura institucional, cujo funcionamento e reprodução independem da existência de acordo (ao contrário da moral), mas ao mesmo tempo influencia nas razões para agir das pessoas, que o enxergam, assim, como um fenômeno normativo (Bix, 2010, p. 16-17).

Diante de tal complexidade, poderia se especular que qualquer abordagem do direito seria parcial. É possível, de um lado, meramente descrever as instituições, de forma "neutra", desconectada de valores, mas essa descrição não será suficiente para caracterizar fenômeno jurídico como um fenômeno doador de razões para ação. De outro lado, uma abordagem avaliativa, voltada às questões de razão prática, desconsideraria o seu lado institucional, sendo incapaz de compreendera força das instituições, que se manifesta não só no momento em que se "escolhe" o que será lei, mas também na reprodução cotidiana do sistema, que se perpetua baseado na ideia de validade ou "força de lei" (BIX, 2008, p. 218).

A parcialidade projetou-se no embate entre positivismo, como teoria do direito que descreve as fontes das regras jurídicas, e jusnaturalismo, como teoria do direito que avalia as melhores soluções jurídicas, formuladas em termos de soluções de razão prática. O positivismo jurídico tentou abarcar a normatividade sem transformar o direito em um subproduto da moral, mas a crítica de Hart às teorias que o precederam mostrou que essa tentativa não foi bem sucedida.

Nesse contexto, $O$ Conceito de Direito é uma contribuição para a superação da controvérsia entre positivismo e jusnaturalismo por conceber o fenômeno jurídico a partir de duas ideias que haviam sido guardadas por essas teorias: "a de que o direito não é simples expressão da vontade ou subjetividade, fenômeno ao mesmo tempo existente e distinto dos fenômenos meramente naturais" (jusnaturalismo) e de que "a juridicidade é um fenômeno social para o qual nenhum fundamento absoluto ou transcendente é requerido" (positivismo). (MICHELON JR, 2004, p. 171) 
A importância da teoria do direito de H. L. A. Hart pode ser vista como uma decorrência do esforço do autor de, em contraposição à teoria do comando de John Austin - voltada inteiramente ao "lado vontade" do direito -, revelar que qualquer abordagem da prática jurídica deve levar em conta o ponto de vista interno de seus participantes considerando, dessa forma, o "lado razão". A teoria de Hart avança, assim, ao descrever o direito como prática social normativa. Essa empreitada só se torna possível, como será visto abaixo, com a atribuição de um status especial ao ponto de vista interno.

\subsection{O ponto de vista interno como fonte de normatividade e o estatuto metodológico da teoria do direito}

A teoria do direito, no momento em que se afirma como um campo especializado de investigações, "herda" das ciências sociais os problemas metodológicos próprios a estas: em primeiro lugar, a discussão sobre a necessidade de forjar um método próprio ou a viabilidade de usar um método análogo ao das ciências naturais; em segundo lugar, a possibilidade de realização de teorias sociais puramente descritivas, livres de qualquer tipo de pretensão avaliativa (PERRY, 1995, p. 98).

A essas questões já suficientemente complexas, a teoria do direito acrescenta problemas metodológicos "especiais" porque, mais que uma ciência social, ela também lida com questões de filosofia da razão prática. Como visto acima, o direito é uma prática doadora de sentido, que provê razões para ação (ou pelo menos é percebido dessa forma). Assim, perguntas difíceis se colocam para o teórico: O que são propriamente razões para ação? Uma prática social pode fornecer razões para agir? Se sim, de que tipo? Ela pode fazer com que o sujeito adquira razões morais que ele não teria de forma independente da prática? (Ibid., p. 97-98).

Ainda que Hart não tenha fornecido de forma explícita uma abordagem sobre as questões metodológicas, sua teoria foi voltada, em grande medida, a apresentar um procedimento teórico que solucionasse tais questões. A chave para tanto foi o argumento de que o ponto de vista de interno deve ser abarcado pela teoria.

Com esse argumento, Hart localiza-se na tradição da teoria social comprometida com uma metodologia "compreensiva" 25 , cuja referência central é a obra de Max Weber ${ }^{26}$.

25 “'Compreensão’ significa [...] apreensão interpretativa do sentido ou da conexão de sentido: a) efetivamente visado no caso individual (na consideração histórica), ou b) visado em média e aproximadamente (na consideração sociológica em massa), ou c) o sentido ou conexão de sentido a ser 
Trata-se da formulação de um método próprio das ciências sociais, que afirma a primazia da interpretação do sentido visado pelas ações ou da conexão de sentido entre ações, em oposição à explicação causal derivada de observação externa. Em algum sentido, Hart é, portanto, um interpretativista, para usar a expressão que será associada de maneira mais comum a Ronald Dworkin.

A afirmação de correção desse método para o estudo de práticas normativas como o direito não significa, no entanto, uma afirmação da impossibilidade de descrever essas práticas sem recorrer a julgamentos avaliativos. Deve se lembrar do que foi dito acima, sobre a teoria abarcar um ponto de vista interno, mas não ser feita deste ponto de vista. $\mathrm{Na}$ verdade, para Hart, a necessidade de referência à atitude interna é, antes de tudo, resultado de uma demanda por maior precisão descritiva.

O "aspecto interno" é introduzido por Hart no momento em que, constatada a impossibilidade de descrever a noção de obrigação por meio de comandos que produzem obediência habitual, ele formula a noção de regras sociais como práticas sociais complexas que se diferenciam dos hábitos. A diferença reside justamente no aspecto interno, que é característico das regras, e consiste na adoção de uma "atitude crítica reflexiva" (HART, 2005, p. 66) em relação ao padrão convergente de comportamento.

Tal "atitude crítica reflexiva" só pode ser tomada de um ponto de vista interno à própria regra. Ela consiste em usar o padrão de comportamento para realizar críticas àqueles que dele desviam, de tal maneira que esse padrão é aceito como uma "boa razão" para realizar a crítica, que é "encarada como legítima ou justificada" (Ibid., p. 65, grifos no original).

Um observador desse comportamento pode adotar duas atitudes para descrevê-lo. Ele pode se limitar a descrever as regularidades do comportamento e assim ser capaz de calcular com alguma precisão quando uma atitude de desvio será punida.

construído cientificamente (como 'ideal-típico') para o tipo puro (tipo ideal) de um fenômeno frequente" (WEBER, 2004, p. 6).

${ }^{26}$ Deve-se notar, entretanto, que, ainda que tenha recentemente se mostrado que a influência de Weber sobre a obra de Hart foi maior do que inicialmente suposto (v. LACEY, 2006), a referência mais imediata de Hart na formulação do argumento do ponto de vista interno foi o filósofo da ciência Peter WINCH (1973). O objetivo de Winch é defender métodos filosóficos para as ciências sociais contra a ideia de que esta deva estar baseada em métodos de ciência natural (como defendia um positivismo de tipo comteano). Para tanto, faz uma derivação do argumento wittgensteiniano sobre "seguir regras" (WITTGENSTEIN, 2009, §§ 185242), como um argumento que mostra o caráter necessariamente social da atividade conceitual, para outras formas de interação humana além da linguagem. Para uma abordagem sobre a crítica de Peter Winch a Weber (segundo a qual este não teria levado às últimas consequências o argumento do sentido de "eventos psíquicos" - a compreensão da regra - como algo distinto de eventos empíricos que influenciam causalmente no curso das ações) e a influência dessa crítica na obra de Hart, ver MACEDO JR, p. 77-81. 
Alternativamente, pode, "sem ele próprio aceitar as regras, afirmar que o grupo aceita as regras e pode assim referir-se do exterior ao modo pelo qual eles estão afectados por elas, de um ponto de vista interno" (Ibid., p. 99).

Hart, como se sabe, adota a segunda alternativa como a mais correta para a realização da teoria do direito. Mas o que há de errado com a primeira em termos metodológicos? Apenas se interpretarmos Hart como estando preocupado com algo mais do que a mera descrição de padrões de comportamento, podemos entender o erro do ponto de vista externo extremo:

a interpretação em termos de previsibilidade deixa na sombra o facto de que, quando existem regras, os desvios delas não são simples fundamentos para a previsão de que se seguirão reações hostis ou de que os tribunais aplicarão sanções aos que as violem, mas são também a razão ou justificação para tal reação e para a aplicação de sanções (HART, 2005, p. 94).

A existência de regras significa, portanto, a existência de razões ou justificações para aqueles que as veem de um ponto de vista interno. Assim, o entendimento deste ponto de vista é necessário não só para adicionar precisão descritiva à teoria, ele é necessário para que a normatividade do direito seja explicada, pois é somente do ponto de vista de quem adota a atitude crítica reflexiva com relação às regras - ou seja, de quem as usa (Ibid.,, p. 108) - que as razões para ação podem, de fato, existir.

É partir dessa pressuposição metodológica que Hart construirá sua caracterização de um sistema jurídico. Segundo tal caracterização, sistemas jurídicos modernos surgem quando, a um conjunto de regras sociais que estabelecem obrigações, são somadas outras regras - estas secundárias, porque elas se referem às regras primárias de obrigação e não exatamente à conduta dos agentes. Tais regras surgem como "remédios" (Ibid., p. 103) para um sistema simples de regras primárias, que apresenta problemas como incerteza, imobilidade e ineficácia.

A ineficácia de um sistema simples, que possui apenas uma "pressão social difusa", é sanada pela introdução de regras de julgamento, "que dão poder aos indivíduos para proferir determinações dotadas de autoridade respeitantes à questão sobre se, numa ocasião concreta, foi violada uma regra primária" (Ibid., p. 106). O caráter estático do sistema simples, que implica na impossibilidade de adaptar as regras às mutações sociais, é sanado pela introdução de regras de alteração, que conferem "poder a um indivíduo ou a um corpo de indivíduos para introduzir novas regras primárias para a conduta da vida do grupo, ou de certa classe dentro dele, e para eliminar as regras antigas” (Ibid., p. 105). 
Já o "remédio" para a incerteza do sistema simples de regras primárias é a regra de reconhecimento, por meio da qual é possível identificar quais regras primárias de obrigação de fato existem em um dado sistema. A existência da regra de reconhecimento é uma "questão de fato" que só pode ser afirmada externamente. Internamente, a sua existência é manifesta pelo seu uso como parâmetro para identificar a validade das regras: "a regra de reconhecimento apenas existe como uma prática complexa, mas normalmente concordante, dos tribunais, dos funcionários e dos particulares, ao identificarem o direito por referência a certos critérios" (HART, 2005, p. 121). Assim como as demais regras, ela pode, portanto, ser vista por duas perspectivas: "uma está expressa na afirmação externa de facto de que a regra existe na prática efetiva do sistema, a outra está expressa nas afirmações de validade, feitas por aqueles que a usam para identificar o direito" (Ibid., p. 123).

Ao caracterizar sistemas jurídicos modernos, Hart atribui, portanto, um papel central à noção de regras sociais. É por meio da atitude interna em relação a essas regras que podemos entender a maneira pela qual o direito funciona como uma prática doadora de razões. No ponto de vista interno, a ocorrência da regra, somada à incidência dos fatos pertinentes discriminados pela regra, faz surgir razões para agir. A normatividade do direito é explicada, assim, em termos de regras sociais. Dessa forma, a teoria de Hart poderia ser vista como uma resposta à dupla ambição metodológica da teoria do direito: ela explica o direito como uma prática social (um sistema de regras) cuja normatividade surge da atitude dos próprios participantes da prática (a adoção de um ponto de vista interno no qual a prática é aceita como razão para agir) ${ }^{27}$.

\subsection{O "positivismo metodológico" de Hart e o "demônio interpretativista"}

Para concluir a exposição sobre a teoria hartiana, e introduzir a discussão do interpretativismo, é interessante analisar um argumento segundo o qual a pretensão de Hart de dar conta dessa dupla ambição metodológica da teoria do direito parece tê-lo levado muito próximo ao tipo de metodologia que será proposta por Dworkin.

\footnotetext{
${ }^{27}$ Em sentido semelhante, cf. Stephen Perry: "We can now see that, for Hart, the content of the internalist thesis is more specific: the theorist must be able to grasp how law is believed by at least some of its participants to give them reasons for action. In fact his formulation of the thesis is more specific still: the theorist must understand and take account of the viewpoint of those who accept social rules, because such acceptance in fact gives them reasons for action. The justification for construing the internalist thesis in this way takes us back to the dual ambitions of jurisprudence.” (PERRY, Methodology, p. 105)
} 
O autor central neste debate é Stephen Perry, um dos autores centrais no debate metodológico $^{28}$, que, em vários textos relacionados ${ }^{29}$, avançou a tese de que Hart teria se comprometido com alguns elementos do que Dworkin veio denominar de interpretativismo.

Perry, em primeiro lugar, reitera que Hart quis fazer sua teoria do ponto de vista externo, ainda que abarcando o ponto de vista interno ${ }^{30}$. Em segundo lugar, afirma que o problema de Hart foi pretender fazer uma teoria descritiva-explanatória, enquanto que o método de análise conceitual, por ele utilizado, não permitiria esse tipo de escolha metodológica. Na verdade, poderia se argumentar que a noção de análise conceitual, se adequadamente abordada, não seria muito diversa do que Dworkin chama de interpretação (PERRY, 1998, p. 433).

$\mathrm{O}$ autor diferencia então entre dois tipos de positivismo: o positivismo substantivo, que afirma não existirem conexões necessárias entre a moralidade e o conteúdo do direito, e o positivismo metodológico, que afirma a possibilidade da descrição moralmente neutra de um fenômeno social particular, como o direito. O positivismo metodológico, em outras palavras, afirma que não há conexões necessárias não entre a moralidade e o direito, mas entre a moralidade e a teoria do direito. (PERRY, 1998, p.427) Essa diferenciação é útil para localizar o problema desta dissertação: ele está voltado à discussão de Dworkin com o positivismo metodológico, e não propriamente com o positivismo substantivo ${ }^{31}$.

Segundo Perry, a teoria descritiva-explanatória é a forma mais evidente de positivismo metodológico, e entende a teoria do direito como uma "espécie de empreendimento científico cujo ponto é formular, de um ponto de vista externo, teorias

${ }^{28}$ Cf. LEITER, 2007 e especialmente OBERDIEK \& PATTERSON, 2007, p. 3.

29 PERRY, 1995; 1998; 2006

${ }^{30}$ Ao contrário do que argumentam outros comentadores, como COLEMAN (2001). A realização da teoria do ponto de vista interno, por outro lado, é explícita na obra de Dworkin. A melhor citação nesse sentido encontra-se em $O$ Império do Direito: "This book takes up the internal, participant's point of view; it tries to grasp the argumentative character of our legal practice by joining that practice and struggling with the issues of soundness and truth participants face" (DWORKIN, 1986, p. 14).

${ }^{31}$ Uma questão que poderia se colocar é se o interpretativismo exige a aceitação de que o direito (não a teoria) está ligado à moral. Se fosse assim, a questão metodológica em Dworkin estaria inevitavelmente ligada à teoria substantiva. Em outras palavras, não seria possível ser interpretativista e positivista ao mesmo tempo. O próprio Dworkin parece sugerir que não é este o caso, ao falar em "positivismo interpretativo" (Dworkin, 2006b, p. 178). Essa questão é interessante, pois revelaria o quanto a metodologia dworkiniana seria de fato indiscernível de sua teoria substantiva. Acredito que, de fato, não seja possível fazer essa distinção. Dworkin é claro em afirmar que sua própria teoria da interpretação é colocada de um ponto de vista interpretativo e que a "epistemologia integrada" é uma exigência de sua teoria do valor único. No entanto, pode ser que, ainda que a teoria esteja de fato integrada nesse nível mais abstrato, a progressiva concretização da interpretação permite que, em níveis mais específicos da teoria (que opera em estágios, como será visto no capítulo seguinte), um interpretativista discorde da abordagem de Dworkin 
sociais descritivas e moralmente neutras sobre o mundo social" (PERRY, 1998, p.436). ${ }^{32}$ A caracterização do fenômeno social que será feita por essa teoria pretende ter poder explanatório, ou seja, pretende ter as virtudes metateóricas normalmente usadas para avaliar as teorias científicas, como simplicidade, poder preditivo e outras.

$\mathrm{O}$ argumento do autor é de que, mesmo que Hart tenha pretendido fazer uma teoria desse tipo, isso não teria ocorrido. Hart teria entendido "poder explicativo" não no sentido científico tradicional, mas como a propriedade daquilo capaz de elucidar os conceitos que constituem a estrutura do pensamento jurídico ${ }^{33}$. E elucidar, nesse sentido, não seria o mesmo que descrever.

Para entender esse ponto, é preciso notar que Hart, ao propugnar a necessidade da teoria de abarcar o ponto de vista interno, estaria adotando, como já examinado acima. a noção de verstehen da filosofia das ciências sociais, o que significa propor um entendimento sobre como os participantes da prática veem seu próprio comportamento. (PERRY, 1998, p.441) Esse entendimento não viria de um mero conjunto de proposições descritivas. Na verdade, nenhum conjunto de proposições constitui propriamente uma teoria científica, a menos que possa fornecer predições testáveis ou conceitualizar sobre o mundo de um jeito novo ou abstrato. Mas, afirma Perry, Hart

não está aparentemente interessado em poder preditivo, e todo o ponto de sua abordagem é descrever conceitualizações existentes, não propor novas conceitualizações. Para encontrar um conjunto de proposições descritivas que constituem a base de uma teoria (não-científica) significativa, está claro que, antes de tudo, nós devemos observar a prática com um propósito particular em mente. O de Hart é, como eu disse, oferecer uma análise externa da conceitualização dos participantes sobre sua prática, o que significa olhar a conceitualização de fora. Portanto, a particular abordagem descritiva de Hart, focando no fenômeno da aceitação, presumivelmente se transforma em uma teoria porque, como Hart enfatiza em uma série de passagens em $O$ Conceito de Direito, a abordagem supostamente 'elucida' ou 'esclarece' os conceitos que os participantes usam (PERRY, 1998, p.442, grifos acrescentados). ${ }^{34}$

\footnotetext{
${ }^{32}$ Tradução livre de "Legal theory is, on this view, a form of scientific enterprise the point of which is to advance, from an external viewpoint, descriptive, morally neutral theories of the social world".

${ }^{33}$ Hart, ao mencionar um dos aspectos centrais de sua teoria - o fato de o direito ser constituído por uma união de regras primárias e secundárias - afirma que "We accord this union of elements a central place because of their explanatory power in elucidating the concepts that constitute the framework of legal thought" (HART, 1997, p. 81, grifei).

${ }^{34}$ Tradução livre de "[..] is not apparently interested in predictive power, and the whole point of his approach is to describe existing conceptualizations rather than to create new ones. To find a set of descriptive statements that constitutes the basis of a meaningful (non-scientific) theory, it is first of all clear that we must be observing the practice with a particular purpose in mind. Hart's purpose is, as I have said, to offer an
} 
Não seria claro como a ideia de elucidação poderia ser apenas outro nome para "poder explicativo". Se fosse esse o caso, a teoria de Hart teria que competir com outras teorias, inclusive com as teorias behavioristas (oferecidas do chamado "ponto de vista externo extremo",35), já que, mesmo que estas estejam erradas em excluir a consideração dos estados mentais dos participantes em sua abordagem sobre o comportamento social, disso não se segue que elas não possam ter inclusive mais poder explicativo (no sentido científico acima referido) que a teoria de Hart - podem, por exemplo, proporcionar predições acuradas, algo que Hart nem se propõe a fazer. Além disso, uma teoria científica com grande poder explicativo também pretende ser precisa, e a precisão seria uma meta estranha para quem quer fazer "elucidação" ou "esclarecimento" de conceitos: a descrição acurada de como eles são usados pelos participantes deveria reportar todas as confusões e obscuridades desse uso e, não seria, assim, uma verdadeira elucidação ${ }^{36}$.

Obviamente, não é o objetivo de Hart fazer esse tipo de observação passiva, que apenas coleta diversos usos. Segundo Perry, seu objetivo, ao propor a análise do conceito de direito (mas também de conceitos como obrigação e autoridade), teria sido dar conta do problema da normatividade do fenômeno jurídico. A normatividade estaria expressa no fato de o discurso jurídico ser permeado por termos normativos, como "obrigação", “direito" e "dever", e de o direito nos vincular, por meio da legislação e da adjudicação, a obrigações que de outra maneira não teríamos. (Ibid., p. 445)

Assim, a afirmação de Hart de que o direito é constituído de regras aceitas (estando fundado em uma regra última que é pura aceitação, a regra de reconhecimento) não seria meramente empírica, mas uma elaboração conceitual que pretende esclarecer, e não meramente reportar, o que significa a atitude daqueles que agem conforme o direito.

external analysis of the participants' conceptualization of their practice, which means looking at that conceptualization from the outside. Thus, Hart's particular descriptive account of law, focusing as it does on the phenomenon of acceptance, presumably becomes transformed into a theory because, as Hart emphasizes at a number of points throughout The Concept of Law, the account is supposed to "elucidate" or "clarify" the concepts that participants use [...]".

35 O ponto de vista externo extremo é o daquele observador que não se refere ao ponto de vista interno adotado pelos participantes e, assim, não faz suas descrições em termos de regras ou de conceitos relacionados a regras (como obrigação, dever etc.) (HART, 1997, p. 89).

36 Neste ponto, trata-se do chamado "paradoxo da análise": uma análise de conceitos não poderia ser ao mesmo tempo informativa e correta, pois, sendo correta, apenas reporta aos participantes da prática o que eles já sabem. Dworkin, com a ideia de conceito interpretativo, pretende ter resolvido esse paradoxo, pois uma concepção interpretativa bem sucedida de um conceito realmente revela algo novo sobre ele (DWORKIN, 2011, p.180). 
Mas essa tarefa de elucidação ou esclarecimento teria falhado, pois Hart, ao "insistir em simplesmente descrever o fenômeno da aceitação, e não indagar as condições sob as quais a aceitação poderia ser justificada" (PERRY, 1998, p. 457) ${ }^{37}$, não conseguiria mostrar as razões para agir dos participantes, fazendo, assim, uma abordagem insuficiente do ponto de vista interno. Em outras palavras, Perry sugere que o compromisso de Hart com o positivismo metodológico teria o afastado de sua pretensão inicial de elucidar o conceito de direito por meio de uma abordagem do ponto de vista dos próprios participantes.

Assim, Perry conclui que a análise conceitual externa seria impossível, e o tipo de análise conceitual mais adequada, a interna, acabaria por colapsar no interpretativismo de Dworkin. O ponto central do argumento volta-se à questão da normatividade do direito, como algo que surge apenas na conceitualização que os participantes fazem de sua prática. Para abordar tal problema, a descrição externa da prática é um método insuficiente.

Mas disso decorreria a necessidade de que o teórico fizesse uma avaliação moral das crenças e atitudes em relação ao direito? Um argumento que poderia ser oferecido em favor de Hart (DICKSON, 2004, p. 132-133), é o de que sua teoria poderia ser entendida nessa chave. A crítica de Perry teria sido mal formulada ao eleger como alvo uma metodologia "descritiva-explanatória" que, da maneira caracterizada por ele, não é o método empregado por nenhum teórico. Perry teria dado ao teórico uma escolha muito estrita: ou ele tem uma inclinação descritivista e registra e reproduz passivamente o cenário jurídico que observa ou, se pretende oferecer uma explicação das características do direito (que é a pretensão de todo teórico), adota a análise conceitual interna.

Ainda segundo esse argumento, qualquer teoria explanatória tem aspectos avaliativos e, assim, é incorreto supor que ela seja "passiva" da maneira como Perry coloca. Isso porque pelo menos dois juízos avaliativos básicos devem ser feitos sobre os dados: os juízos de significação e importância de tais dados para a teoria. É nesse sentido que seria possível falar de uma teoria que, em sua parte avaliativa, seja sensível às avaliações da prática feitas pelos próprios participantes.

O desafio colocado por Perry é, no entanto, mais profundo do que a defesa de Hart parece reconhecer: ao afirmar que a noção de análise conceitual, se levada às últimas consequências, pode exigir a adoção do interpretativismo, Perry não está colocando uma alternativa estrita ao teórico, entre a descrição passiva (e inútil) e o interpretativismo. Não

${ }^{37}$ Tradução livre de "[...] insists on simply describing the phenomenon of acceptance rather than inquiring into the conditions under which acceptance might be justified [...]". 
é a "inutilidade" da teoria descritiva-explanatória que deixa o teórico com a opção "única" do interpretativismo. Na verdade, Perry afirma expressamente que um mero "conjunto de proposições descritivas não constitui uma teoria de qualquer tipo", ele se "torna uma teoria ao fazer predições (preferivelmente testáveis) e/ou ao conceitualizar o mundo de um jeito novo ou abstrato" (PERRY, 1998, p. 442).

Assim, o argumento não é o de que a teoria descritiva é inviável para a teoria do direito por ser um inútil "exercício de ditado" (DICKSON, 2004, p. 131). O verdadeiro argumento é de que a prática do direito, por ser uma prática doadora de razões, faz com que a teoria descritiva não possa ser um meio de esclarecimento conceitual (ainda que ela possa servir a outros fins, como predição e capacidade explicativa).

Hart teria, portanto, flertado com o interpretativismo, mas não o levado às últimas consequências. $\mathrm{O}$ a análise de Perry parece sugerir é que, "se você dança com o demônio interpretivista, não é fácil manter distância” (PERRY, Interpretation and Methodology, p.135).

No próximo capítulo, examinaremos mais de perto esse "demônio", tal como caracterizado por seu maior defensor. 


\section{O DIREITO COMO INTERPRETAÇÃO: PROPOSTAS E DESAFIOS}

Neste capítulo, pretendo expor os primeiros argumentos formulados por Dworkin para defender que o direito é uma prática interpretativa. Essa tese fez com que ele abrisse uma divergência radical com o positivismo jurídico, mesmo na "versão hermenêutica" surgida com Hart e continuada por teóricos como Joseph Raz (MACEDO JR., 2012, p. 46).

Após a exposição dos argumentos de Dworkin, considerarei brevemente a teoria rival de Raz, que deve nos levar então à formulação mais recente do interpretativismo, abordada no próximo capítulo.

\section{Por uma teoria da controvérsia}

A primeira crítica de Ronald Dworkin ao positivismo jurídico na versão hartiana aparece no clássico artigo "Modelo de Regras I" (DWORKIN, 1978, p. 14-45). Apesar de introduzir a mais que famosa distinção entre princípios e regras, nesse artigo, a crítica dworkiniana ainda é apresentada em uma versão preliminar. O próprio Dworkin, em sua obra mais recente, reconhece que essa primeira formulação da crítica ao positivismo se diferencia do seu pensamento subsequente por apresentar uma visão equivocada de como o direito se relaciona à moral (DWORKIN, 2011, p. 402).

O argumento do "Modelo de Regras I" é, grosso modo, de que a descrição dos sistemas jurídicos fornecida pelo positivismo não consegue abarcar padrões que se diferenciam das regras, mas que se colocam como obrigatórios na prática jurídica (os princípios). Trata-se de uma deficiência descritiva da teoria positivista, que, ao apresentar o direito como um "modelo de regras" 38 , não consegue indicar todas as situações sociais

\footnotetext{
${ }^{38}$ Alguns comentadores (SHAPIRO, 2007, p. 3) afirmam que essa crítica não poderia ser dirigida a Hart, pois ele nunca teria afirmado que o direito é um sistema de regras no sentido que Dworkin atribui à expressão: padrões a serem aplicados no esquema tudo-ou-nada. De fato, no Posfácio a $O$ Conceito de Direito, Hart afirma que "não tencionava sustentar, através do uso que diz da palavra 'regra', que os sistemas jurídicos só contêm regras de 'tudo-ou-nada' ou regras 'quase-conclusivas'. Ele afirma ter chamado atenção para o que designou, segundo ele mesmo, “de forma infeliz”, “"padrões jurídicos variáveis’, que especificam factores que devem ser levador em conta e ponderados com outros". Apesar disso, reconhece Dworkin é credor de grande reconhecimento por ter mostrado e ilustrado a importância desses princípios e o respectivo papel no raciocínio jurídico, e, com certeza, eu cometi um sério erro ao não ter acentuado a eficácia não conclusiva deles" (HART, 2005, p. 325). Essa confusão em torno de terminologia mostra o quanto a "primeira crítica" dworkiniana pode ser enganadora, não sendo representativa de todas as questões abarcadas pelo debate HartDworkin. Não me preocupo aqui com a questão de diferenciar os "dois momentos" da crítica e entender em que medida Dworkin abandonou os argumentos formulados em "Modelo de Regras I" (ainda que seja certo
} 
em que julgamos haver obrigações (DWORKIN, 1978, p. 30). O aspecto dessa crítica rejeitado posteriormente por Dworkin é a apresentação do direito e da moral como dois sistemas separados, cuja interação precisa ser adequadamente captada pelo teórico. Essa visão dos "dois sistemas" é veementemente rejeitada pelo interpretativismo, que afirma a existência de um único tipo de raciocínio - o raciocínio interpretativo - nos campos do direito e da moral, que, assim, estão integrados no mesmo empreendimento interpretativo.

Essa questão deverá ficar mais clara adiante, de qualquer modo, o importante a ser ressaltado aqui é que as bases para construção do interpretativismo não aparecem propriamente em "Modelo de Regras I", mas em um artigo lançado em resposta às críticas recebidas por essa primeira formulação da teoria. Em "Modelo de Regras II" (Ibid., 1978, p. 46-80), Dworkin afirma que as objeções recebidas pelo primeiro artigo tinham como pressuposto a adoção de uma tese central em $O$ Conceito de Direito, "uma tese que pertence à filosofia moral e jurídica. Ela afirma, em sua versão mais forte, que nenhum direito ou dever de qualquer tipo pode existir a não ser em razão de uma prática social uniforme de reconhecimento desses direitos e deveres" (Ibid., p. 48) ${ }^{39}$. Assim, o teste para o reconhecimento do direito seria a existência de uma prática social uniforme.

Essa tese é a "teoria da regra social", que será o alvo da crítica de Dworkin. O ponto central dessa crítica será mostrar que a teoria não consegue explicar todos os casos em que as pessoas afirmam existir um dever ${ }^{40}$. Pela teoria da regra social, em sua versão forte, sempre que alguém afirma um dever, essa pessoa está pressupondo a existência de uma regra social e mostrando uma atitude de aceitação em relação a essa regra. Em uma versão mais fraca, a pressuposição de existência da regra social ocorre pelo menos em

que eles os abandonou em alguma medida, como será visto adiante no texto). De qualquer maneira, penso que "O Modelo de Regras II" é um texto que sintetiza de forma precisa a teoria interpretativista que será posteriormente desenvolvida, e por isso começo a exposição por ele, deixando de lado a formulação do "Modelo de Regras I". Que este seja um texto inadequado para acessar o debate é reconhecido por um dos especialistas no tema: "In "The Model of Rules I," Dworkin claimed that the dispute between him and Hart concerned whether the law is a model of rules. This formulation of the debate, though, is misleading - and has misled several generations of law students - because, as it is now generally recognized, Hart never claimed that the law is simply a model of rules (in Dworkin's sense of "rule"), nor is he committed to such a position." (SHAPIRO, 2007, p. 3).

39 Tradução livre de "[...] a thesis which belongs to moral as well as to legal philosophy. It argues, in its strongest form, that no rights or duties of any sort can exist except by virtue of a uniform social practice of recognizing these rights and duties."

40 Deve se notar que Dworkin usa a palavra "dever" no mesmo sentido em que Hart usou "obrigação". Dworkin constrói sua crítica em torno da análise do dever dos juízes de aplicar a lei e justifica o uso da palavra dever apenas por ser mais comum para esses casos. De qualquer maneira, o próprio Dworkin ressalta que entende a análise de Hart como sendo aplicável tanto a dever quanto a obrigação e que o próprio Hart teria usado ambos os termos para se referir a mesma coisa (DWORKIN, 1978, p. 49, nota 1). 
alguns casos, ainda que não em todos (DWORKIN, 1978, p. 52). Dworkin pretende refutar ambas as versões, primeiro em sua versão forte, depois em sua versão fraca.

A versão forte da teoria não se sustenta quando pensamos nas afirmações de deveres que são controversas, ou seja, afirmações para as quais a existência de uma base social, de uma prática, não pode ser demonstrada. Como exemplo, Dworkin refere-se a afirmações feitas por um vegetariano: este afirma que temos o dever de não matar animais para comê-los. Obviamente, não há nenhuma prática social que possa suportar essa afirmação, nenhuma regra social que o vegetariano esteja aceitando. Se dissermos que o vegetariano, ao afirmar a existência do dever de não comer carne, está, na verdade, dizendo que uma prática social nesse sentido deveria existir, estaríamos distorcendo sua afirmação. O vegetariano afirma que o dever já existe, e a teoria da regra social pode acomodar sua situação apenas se distorcer o que ele quer realmente dizer (Ibid., p. 52-53).

Essas situações de afirmações de deveres controversos nos mostra que a teoria só poderia se sustentar caso fosse enfraquecida, para se aplicar apenas aos casos nos quais a afirmação de dever recebe a concordância da comunidade. Mas, mesmo nesses casos, ela falharia, pois não levaria em consideração dois tipos muito diversos de moralidade que podem ocorrer em uma comumidade. Uma comunidade tem uma moral convencional quando a convergência da prática é um fundamento para que se afirme a existência de uma regra. Nesse caso, as pessoas não afirmariam ter determinado dever se as demais pessoas também não o tivessem. Por exemplo, as pessoas não diriam ter a obrigação de esperarem em fila para serem atendidas em bancos caso essa obrigação não fosse também aceita pelas demais pessoas. Este não é o caso da moralidade concorrente. Nesta, as pessoas podem concordar na afirmação de uma mesma regra normativa, mas não contam o fato do acordo como um fundamento para a existência dessa regra. O exemplo usado por Dworkin é o dever de não mentir: podemos acreditar que as pessoas têm esse dever, mesmo que a maior parte das pessoas, de fato, minta. (Ibid., p. 53-54)

Então, mesmo nas situações em que a afirmação da existência do dever é suportada por certa prática social convergente, seria necessário restringir a aplicação da teoria da regra social apenas para os casos de moralidade convencional: é apenas nestes casos que a prática convergente constitui o dever. Mas, ainda que restrita a apenas esse pequeno número de situações, a teoria da regra social não poderia se sustentar, pois não explica os casos em que, concordando que a prática gera algum tipo de dever, as pessoas ainda discordam sobre a abrangência desse dever (Ibid., p. 54). Por exemplo, podemos concordar que as pessoas devem permanecer em silêncio durante as sessões de cinema, 
mas isso vale também para as sessões de filmes infantis, em que pais levam filhos pequenos para assistir?

Nesses casos, pode se dizer que existe uma regra social incerta, mas esse argumento minaria o próprio argumento de existência da regra: se esta é constituída de uma atitude, então não podemos julgá-la incerta quando todos os fatos relevantes sobre o comportamento social são conhecidos (DWORKIN, 1978, p. 54).

Estes s argumentos de Dworkin mostram que a teoria da regra social não se sustenta:

Quando as pessoas afirmam regras normativas, mesmo nos casos de moralidade convencional, elas tipicamente afirmam regras que diferem em escopo e detalhe, ou que difeririam se cada pessoa articulasse sua regra em maior detalhe. Mas duas pessoas cujas regras diferem, ou difeririam se elaboradas, não podem estar recorrendo à mesma regra social, e pelo menos uma delas não pode estar apelando para nenhuma regra social. [...] Então a teoria da regra social deve ser enfraquecida para uma forma inaceitável se quiser superar esses argumentos. Deve se dizer que ela é aplicável somente em casos, como em alguns jogos, nos quais os participantes aceitam que, se um dever é controverso, então ele não é um dever. Ela então não seria aplicável para deveres judiciais. (Ibid., p. 55) ${ }^{41}$

É importante notar o caminho da refutação da teoria da regra social: ele começa na possibilidade de se afirmar um dever sem que este esteja sustentado em qualquer tipo de comportamento convergente e termina nos casos em que, mesmo na existência de uma prática social uniforme - e na qual a convergência de fato fundamenta a normatividade -, ainda é possível haver desacordo sobre a abrangência da regra. Assim, a teoria da regra social vê-se confinada à aplicação em práticas cada vez mais uniformes, até que se mostra que ela poderia valer apenas para alguns tipos de jogos. O argumento de Dworkin percorre, assim, o caminho das práticas sociais mais complexas até as menos complexas, mostrando que, mesmo em casos de máxima uniformidade, é sempre possível haver discordância.

Uma última forma de "salvar" a teoria das regras sociais seria afirmar que ela se aplica não como um limite para os deveres, mas como seu limiar: na existência de

\footnotetext{
${ }^{41}$ Tradução livre de "[...] when people assert normative rules, even in cases of conventional morality, they typically assert rules that differ in scope or in detail, or, in any event, that would differ if each person articulated his rule in further detail. But two people whose rules differ, or would differ if elaborated, cannot be appealing to the same social rule, and at least one of them cannot be appealing to any social rule at all. This is so even though they agree in most cases that do or might arise when the rules they each endorse are in play. So the social rule theory must be weakened to an unacceptable form if it is to survive at all. It must be held to apply only in cases, like some games, when it is accepted by the participants that if a duty is controversial it is no duty at all. It would not then apply to judicial duties."
} 
consenso, os membros de uma comunidade têm pelo menos os deveres abarcados pelo consenso. Para além dos termos da regra, não estaria assentada a existência de nenhum dever ou direito. Assim, no caso das sessões de filmes infantis, por exemplo, a questão da existência do dever de silêncio deve ser definida por argumentos que apelam para algo além da própria prática (DWORKIN, 1978, p. 57).

Mesmo neste caso, Dworkin aponta para uma deficiência da teoria. $\mathrm{O}$ argumento formulado aqui é o gérmen do argumento sobre práticas interpretativas, e por isso é necessário entendê-lo com cuidado.

Não se adéqua a nossa prática moral nem mesmo dizer que uma regra social estipula o nível mínimo de direitos e deveres. Geralmente se reconhece, mesmo como uma característica da moral convencional, que práticas sem propósito (pointless), ou inconsistentes em princípio com outros requisitos da moralidade, não impõem deveres, ainda que, nos casos em que uma regra social exista, apenas uma pequena minoria irá pensar que essa provisão de fato se aplica. Quando uma regra social determinou, por exemplo, que os homens oferecessem algumas cortesias formais às mulheres, a maioria das pessoas disse que as mulheres tinham um direito a elas; mas alguém de qualquer sexo que pensasse que essas cortesias eram um insulto não iria concordar (Ibid., p. 57, grifos acrescentados). ${ }^{42}$

O exemplo dado nesse último argumento é interessante para mostrar que o desacordo pode ser ainda mais abrangente do que se supõe: ele pode atingir até mesmo casos fáceis, nos quais se verifica um acordo na prática sobre o conjunto mínimo de direitos e deveres a serem reconhecidos. Mesmo nesses casos, Dworkin argumenta que pode haver controvérsia: pode ser que o próprio sentido, ou propósito $\left(\right.$ point $\left.^{43}\right)$ da prática sejam colocados em questão.

O argumento mostra o quão abrangente é o erro da teoria da regra social. Ela não capta corretamente a relação entre práticas sociais e julgamentos normativos, pois "acredita que a prática social constitui uma regra que o julgamento normativo aceita; na verdade, a

\footnotetext{
${ }^{42}$ Tradução livre de "It is generally recognized, even as a feature of conventional morality, that practices that are pointless, or inconsistent in principle with other requirements of morality, do not impose duties, though of course, when a social rule exists, only a small minority will think that this provision in fact applies. When a social rule existed, for example, that men extend certain formal courtesies to women, most people said that women had a right to them; but someone of either sex who thought these courtesies an insult would not agree."

${ }^{43}$ A ideia do "point" da prática é essencial na teoria de Dworkin e será adiante analisada. A palavra não tem uma tradução evidente, mas optei na maior parte das vezes por "propósito" ou "intencionalidade".
} 
prática social ajuda a justificar uma regra que o julgamento normativo expressa” (Ibid., p. $57)^{44}$

A crítica de Dworkin à teoria da regra social, tal como formulada em "Modelo de Regras II" mostra que algo mais do que a existência de uma atitude diante da regra é necessária para dizermos que existem direitos ou deveres.

Analisando o exemplo de Hart de que homens que frequentam igrejas assumem que existe uma regra (não mero hábito) segundo a qual devem descobrir as cabeças ao entrarem no templo, ele afirma: "Mas nós vamos querer dizer que a afirmação do frequentador da igreja de que existe uma regra normativa é verdadeira (ou justificada) apenas se certo estado de coisas normativo existe, isto é, apenas se os indivíduos realmente possuem o dever que eles pensam ter no exemplo de Hart" (DWORKIN, 1978, p. 51, grifos acrescentados) $)^{45}$.

Hart, em uma resposta às diversas críticas de Dworkin que foi postumamente editada como um Posfácio a $O$ Conceito de Direito, considera essas palavras - "estado de coisas normativo" - "torturantemente obscuras" (HART, 2005, p. 318-319). Ele afirma que, se Dworkin "quer significar com um estado de coisas normativo a existência de boas razões morais, ou de justitifcação, para fazer o que a regra exige", então sua concepção de regra social é, "decididamente, demasiado forte" (Ibid., p. 318). Hart cita o exemplo de regras de um regime de apartheid para ilustrar a existência de regras sociais aceitas que são consideradas moralmente iníquas. Nem mesmo uma condição mais fraca para a existência de regras sociais - a de que os participantes devam ao menos acreditar na existência de boas razões para a regra - seria aceitável. As razões para aceitação poderiam ser as mais diversas (HART, 2005, p. 319).

Hart, todavia, concede que sua teoria da regra social seria aplicável somente a um grupo de regras marcadas por um "consenso de convenção", ou seja, derivadas da moralidade convencional da maneira como descrita por Dworkin. Já o que Hart denomina o "consenso de convicção" (moralidade concorrente) não poderia ser explicado pela teoria. Assim, ela não serviria como uma explicação adequada da moralidade, seja a moralidade social ou individual (Ibid., p. 318).

\footnotetext{
44 Tradução livre de "It believes that the social practice corutitutes a rule which the normative judgment accepts; in fact the social practice helps to justify a rule which the normative judgment states."

45 Tradução livre de "But we should want to say that the churchgoer's assertion of a nrmative rule is true (or warranted) only if a certain normative state of affairs exists, that is, only if individuals in fact do have the duty that they suppose they have in Hart's example".
} 
No entanto, segundo o próprio Hart, essa restrição da teoria não mudaria o fato de que ela "permanece como um retrato fiel das regras sociais convencionais que incluem, além dos costumes sociais comuns (que podem ser, ou não, reconhecidos como dispondo de eficácia jurídica), certas regras jurídicas importantes que abrangem a regra de reconhecimento, regra esta que é efetivamente uma forma de regra judicial costumeira, que somente existe se for aceite e executada nos actos dos tribunais de identificação do direito e aplicação deste" (HART, 2005, p. 318, grifos acrescentados).

A resposta de Hart, deste modo, mostra que o comprometimento da teoria da regra social com o ponto de vista interno limita-se à identificação de uma atitude de aceitação em relação às regras, que se manifesta em sua prática de uso. Assim, a teoria não se comprometeria com qualquer tipo de justificação moral ou normativa que possa ser tida pelos participantes da prática de uso de regras - esta é, assim, apenas descrita de forma neutra.

A possibilidade de realização de uma teoria desse tipo será desafiada por Dworkin a partir dos desenvolvimentos da crítica à teoria da regra social, que resultarão na teoria interpretativista do direito elaborada em O Império do Direito (DWORKIN, 1986).

\section{Desacordos teóricos e o argumento do ferrão semântico}

Talvez o argumento mais famoso de O Império do Direito seja o do "ferrão semântico", que se tornou um dos tópicos mais debatidos na literatura formada em torno do debate Hart-Dworkin ${ }^{46}$. Apesar disso, a posição desse argumento no debate não é tão clara. Neste tópico, pretendo reconstruir as linhas mestras do interpretativismo por meio de um argumento que considero ter precedência sobre o do "ferrão semântico" e que, caso seja um argumento sólido, não depende deste último para se sustentar. Trata-se da ideia de que o direito é objeto de amplos desacordos teóricos.

\subsection{Desacordos teóricos}

Dworkin apresenta $O$ Império do Direito como um livro sobre desacordos teóricos no direito: "esta obra visa entender que tipo de desacordo é este e então construir e defender uma teoria específica sobre os fundamentos (grounds) adequados do direito"

${ }^{46}$ Ver SATAVROPOULOS, 2001; RODRIGUEZ-BLANCO, 2003; COLEMAN\&SIMCHEN, 2003; RAZ, $1998 ; 2004$. 
(DWORKIN, 1986, p. 11) ${ }^{47}$. Para os fins desta dissertação, estaremos mais preocupados com a primeira parte dessa proposição: é a partir da discussão sobre a natureza dos desacordos teóricos que Dworkin irá construir o argumento de que o direito é uma prática interpretativa e o teórico do direito um intérprete que participa da prática, tanto quanto advogados ou juízes. Essa é a posição que o autor pretende defender nos três primeiros capítulos da obra (DWORKIN, 1986, p. 1-113).

A defesa de uma teoria específica sobre os fundamentos do direito é o segundo momento do projeto dworkiniano, no qual ele desenvolverá sua concepção de "direito como integridade" (DWORKIN, 1986, p. 176-275) como uma teoria jurídica mais adequada que o convencionalismo (Ibid., p. 114-150) e o pragmatismo jurídico (Ibid., p. 151-175). Neste segundo momento, Dworkin já apresenta a própria teoria jurídica como um empreendimento interpretativo, e é neste terreno que pretende defender o "direito como integridade".

A existência desses dois momentos distintos mostra que o interpretativismo não é, estritamente falando, o mesmo que o "direito como integridade". A maneira como esta concepção de direito é apresentada pressupõe a caracterização do direito da prática interpretativa, mas este argumento não necessariamente leva à adoção da concepção dworkiniana de direito como a melhor concepção ${ }^{48}$.

$\mathrm{O}$ argumento do desacordo teórico é o primeiro passo para caracterizar o direito como uma prática interpretativa. Tal argumento pressupõe uma diferença entre dois tipos de afirmações no direito. O primeiro é o que pode se chamar de "proposições jurídicas": são as afirmações que expressam o que o direito permite, proíbe ou habilita as pessoas a fazerem. O segundo tipo de afirmações é o que se chama de "fundamentos do direito": são proposições mais fundamentais em virtude das quais dizemos que as proposições jurídicas são ou não verdadeiras (Ibid., p. 4).

As proposições jurídicas podem ser muito concretas ou muito abstratas. Podemos citar como um exemplo de proposição jurídica razoavelmente abstrata: "são casos de cassação de mandato dos congressistas os previstos no art. 55, I, II e VI, que dependem de decisão da Câmara ou do Senado, por voto secreto e maioria absoluta, mediante aprovação da respectiva Mesa ou de partido político representado no Congresso Nacional, assegurada

\footnotetext{
${ }^{47}$ Tradução livre de "It aims to understand what kind of disagreement this is and then to construct and defend a particular theory about the proper grounds of law."

${ }^{48}$ Este ponto é apresentado aqui apenas como uma maneira de delimitar os argumentos que serão expostos, mas a questão sobre a possibilidade de separar a "teoria metodológica" de Dworkin de sua "teoria substanti1998a" será mais bem endereçada ao final deste capítulo.
} 
ampla defesa" ${ }^{\text {49 }}$. Uma proposição jurídica razoavelmente concreta poderia tomar a seguinte forma: "a perda de mandato de parlamentar condenado em ação criminal julgada pelo Supremo Tribunal Federal poderá ser decretada por este tribunal”. Concretizando ainda mais, poderíamos ter algo do tipo: "O deputado João Paulo Cunha deve perder o mandato como efeito imediato do trânsito em julgado da decisão condenatória da Ação Penal 470".

Como sabemos se tais proposições são verdadeiras? Elas não podem ser simples verdades: elas não são sobre "aquilo que o Direito sussurra para os planetas" (DWORKIN, 1986, p. 4). Deve haver proposições que fundamentam essas verdades, isto é, um segundo tipo de afirmações, que constituem "fundamentos do direito", deve ser capaz de conferir o caráter de verdade às proposições jurídicas.

Um possível fundamento para avaliar o caráter de verdade das proposições acima indicado poderia ser elaborado da seguinte maneira: “A vontade do constitutinte originário e o sentido literal do texto devem nortear a interpretação da Constituição" ${ }^{\text {"50. Esse }}$ fundamento faria a primeira proposição verdadeira e as demais falsas. Mas o que nos diz que este é realmente o fundamento a ser invocado para as proposições?

O desacordo teórico é justamente o tipo de controvérsia que surge quando nos fazemos essa questão. No exemplo acima, as partes discordam sobre o que fudamenta a interpretação constitucional. Um lado acredita que essa interpretação deve estar ancorada no desenho institucional que foi delineado pelo constituinte originário, pois este visa garantir importantes valores - como a completa independência do Legislativo e dos seus membros para dispor de mandatos eletivos - que devem ser guardados mesmo no momento atual da nossa democracia (ou, diriam alguns, principalmente no momento atual da nossa democracia). O outro lado afirma que a interpretação constitucional deve seguir

\footnotetext{
${ }^{49}$ AFONSO DA SILVA, 2012, p. 540.

${ }^{50}$ Nesse sentido: "O fato é que nossa Constituição é explícita em seu artigo 55 , que trata da perda de mandato de deputado ou senador em caso destes sofrerem condenação criminal (item VI, parágrafo $2^{\circ}$ ): 'A perda do mandato será decidida pela Câmara dos Deputados ou pelo Senado Federal, por voto secreto e maioria absoluta, mediante provocação da respectiva Mesa ou de partido político representado no Congresso Nacional, assegurada ampla defesa'.

[...]

Mesmo que paire alguma dúvida sobre tal enunciado, os registros taquigráficos dos debates que envolveram a redação do artigo 55 pelos constituintes, em março de 1988, são esclarecedores da sua vontade originária. Coube ao então deputado constituinte Nelson Jobim a defesa da emenda do também constituinte Antero de Barros: 'Visa à emenda (...) fazer com que a competência para a perda do mandato, na hipótese de condenação criminal ou ação popular, seja do plenário da Câmara ou do Senado'. E, mais adiante, conclui: '(...) e não teríamos uma imediatez entre a condenação e a perda do mandato em face da competência que está contida no projeto'. A emenda foi aprovada por 407 constituintes, entre eles Fernando Henrique Cardoso, Mário Covas, Aécio Neves, Luiz Inácio Lula da Silva, Ibsen Pinheiro, Delfim Netto, Bernardo Cabral, demonstrando a pluralidade do debate empreendido naquele momento" (MAIA, Marco. Respeitar o Legislativo é defender a democracia, Tendências e Debates, Folha de São Paulo, 10 de dezembro de 2012).
} 
as mudanças do sistema político e jurídico, e as novas exigências de moralidade que o período de consolidação democrática impôs a esses sistemas, de maneira que o desenho institucional originalmente pensado pelo constituinte deve ser afastado em prol de um valor superior de moralidade política ${ }^{51}$.

O desacordo teórico é, assim, muito diferente de outro tipo de desacordo, que podemos denominar "empírico". Neste, a divergência existe por não haver concordância acerca da ocorrência ou da satisfação dos fundamentos do direito (DWORKIN, 1986, p. 5). Podemos concordar, por exemplo, que, caso exista uma Súmula Vinculante do Supremo Tribunal Federal que determine a inconstitucionalidade da cobrança de taxa de matrícula em universidades públicas, então temos o direito a não pagarmos a taxa ao requerer a matrícula. Mas discordamos sobre se essa súmula realmente existe ou se ela foi revogada ou reformulada, então não concordamos, na situação concreta, sobre a existência do direito. Os desacordos empíricos são, assim, muito simples, e não há nada de misterioso a respeito deles.

Já os desacordos teóricos revelam uma extraordinária complexidade; apesar disso, segundo Dworkin, eles nunca foram objeto de uma "teoria plausível" (Ibid., p. 6). Pelo contrário, este autor nos apresenta duas possíveis caracterizações de abordagens que passam ao largo da existência desse tipo de desacordo: a "visão do mero fato" e as teorias semânticas.

\subsection{Positivismo hartiano, "visão do mero fato" e teorias semânticas}

Uma abordagem difundida acerca da controvérsia no direito seria a "teoria do mero fato", segundo a qual os fundamentos do direito são factuais e consistem apenas naquilo que já foi decidido no passado pelas instituições jurídicas (legislativos, tribunais e outros). Desacordos teóricos, nesta visão, seriam apenas ilusões: o direito existe como um

\footnotetext{
${ }^{51} \mathrm{O}$ exemplo aqui delineado refere-se a uma das muitas questões controversas que surgiram no julgamento da Ação Penal no 470, o chamado "caso do mensalão", pelo Supremo Tribunal Federal no ano de 2012. Ao final do julgamento, o Tribunal decidiu que deputados federais condenados na ação perderão automaticamente seus mandatos uma vez transitada em julgado a condenação. A decisão afirmou que a exigência de que a Câmara decida sobre a perda do mandato de parlamentares condenados criminalmente (art. 55, VI e $\S 2^{\circ}$ ) deve ser afastada tendo a vista outra disposição constitucional, que determina a cassção de direitos políticos daqueles criminalmente condenados (art. 15) e as exigências de moralidade impostas ao sistema político pela história recente de desenvolvimento institucional do país. Como se sabe, o Presidente da Câmara dos Deputados discorda da decisão e afirma que não irá cumpri-la (no que deve ser acompanhado pelo novo Presidente que será em breve eleito). Ainda que as posições em debate possam ser caracterizadas de maneira diversa da realizada no texto, acredito que este é um ótimo exemplo de desacordo teórico sobre os fundamentos do direito, e revela que esse tipo de desacordo não ocorre somente no momento da adjudicação.
} 
dado, então qualquer desacordo seria, na verdade, apenas uma controvérsia empírica sobre o que já foi decidido (Ibid., p. 7-8).

Esta seria uma visão popular sobre as controvérsias jurídicas, tanto entre os leigos quanto na academia (pelo menos entre filósofos do direito, mas não tão certamente entre os práticos).

Para o público leigo, indagações sobre a verdade de proposições jurídicas refletiriam apenas uma questão de fidelidade à lei. A versão mais "conservadora" dessa visão afirma que os juízes devem respeitar a lei, e não tentar conformá-la a seus próprios propósitos e intenções políticas. Uma versão mais "progressista” afirma, ao contrário, que bons juízes devem preferir a justiça ao direito, que eles devem ser políticos - justamente no sentido que a versão conservadora despreza - e não meros aplicadores mecânicos do direito (DWORKIN, 1986, p. 8).

Já a versão acadêmica da "teoria do mero fato" reconhece que muitas vezes o “dado jurídico" pode não existir: pode ser que não haja decisões passadas a respeito das questões concretas, ou que elas não sejam conclusivas para nenhuma das partes. Nesses casos, a questão central que se coloca é sobre o que os juízes devem fazer na ausência de direito. A indagação sobre a verdade das proposições é substituída, então, por um projeto de emendas ao direito existente. Uma derivação mais radical dessa visão é desenvolvida por realistas e pelo chamado critical legal studies, para quem o caráter vago, incompleto e até mesmo incoerente do direito é uma caraceterística recorrente, e não apenas algo que surge em casos ocasionais. Assim, segundo essa visão acadêmica da "teoria do mero fato", em muitas situações, simplesmente não haveria direito, mas apenas afirmações teóricas com a intenção de encobrir preferências ideológicas ou de classe (Ibid., p. 9).

É interessante notar que a "teoria do mero fato", da maneira como descrita por Dworkin, abrange um vasto espectro, que vai dos "leigos formalistas" aos "céticos acadêmicos". Essas posições teóricas - formalismo e ceticismo sobre as regras - já haviam sido criticadas por Hart, que dedicou o capítulo VII de O Conceito de Direito (HART, 2005, p. 137-168) a sua discussão.

Contra o formalismo, Hart elabora o argumento da "textura aberta do direito", segundo o qual a comunicação de padrões de comportamento, seja por meio de formas gerais (como na legislação), seja por meio de exemplos (como no precedente), sempre guardará certa indeterminação, que é inerente à própria natureza da linguagem (HART, 2005, p. 138-141). E ainda, mesmo que desconsiderássemos essa característica da 
linguagem, não nos seria possível (e nem seria desejável) fazer uma regra tão detalhada que pudéssemos nos esquivar da escolha entre alternativas que toda regra proporciona.

Segundo Hart, seria da natureza humana trabalhar com a existência de duas desvantagens que surgem sempre que se tenta fazer regulações gerais: a "relativa ignorância de fato" e a "relativa indeterminação de finalidade". Um mundo em que tudo é conhecido simplesmente "não é o nosso mundo; os legisladores humanos não podem ter tal conhecimento de todas as possíveis combinações de circunstâncias que o futuro pode trazer" (HART, 2005, p. 141). Assim, são as decisões dos funcionários do sistema e dos tribunais que "determinam o equilíbrio, à luz das circunstâncias, entre interesses conflituantes que variam em pesos, de caso para caso" (Ibid., p. 148).

Já o argumento que refuta o ceticismo sobre as regras parte da própria ideia de ponto de vista interno, chamando atenção para o fato de que, pelo menos em um Estado moderno, os indivíduos "efetivamente mostram toda a série de condutas e atitudes que designamos como o ponto de vista interno" (Ibid., p. 151, grifo acrescentado). A ideia é que podemos ver que as regras jurídicas são realmente usadas como regras, não como meras descrições de hábitos ou previsões. O cético poderia ser interpretado como um "absolutista desapontado", que faz exigências muito fortes para dizer que existe uma regra. Para ele, ou as regras existem de forma absoluta, como em um "paraíso dos conceitos", ou então não são regras, mas sim, meros padrões de comportamento (Ibid., p. 152).

Outro argumento que poderia ser invocado pelo cético, e que também não se sustenta, é o de que as pessoas, inclusive os juízes, usam a regra de forma meramente intuitiva - eles não refletem sobre elas, apenas decidem o que consideram mais correto. Contra esse argumento, Hart afirma que, mesmo que seja o caso que o processo psicológico dos que usam as regras consista em primeiro achar a solução mais correta e depois "procurar" a regra que se adéqua, é sempre a regra que servirá como padrão de justificação: "se o nosso comportamento for posto em causa, estamos dispostos a justificálo por referência à regra” (Ibid., p. 153).

Os argumentos hartianos contra esses dois extremos da teoria jurídica ${ }^{52}$ mostram que o positivismo hartiano não pode ser claramente considerado parte do conjunto de teorias que Dworkin denominou "teoria do mero fato". Esse tipo de teoria é caracterizado da seguinte maneira:

\footnotetext{
${ }^{52}$ Segundo Hart, "O formalismo e o cepticismo sobre as regras são os Cila e Caríbdis da teoria jurídica; são grandes exageros, salutares na medida em que se corrigem mutuamente, e a verdade reside no meio deles" (HART, 2005, p. 161).
} 
Ela sustenta que direito depende apenas de questões de mero fato histórico, que o único desacordo sensato sobre o direito é o desacordo empírico sobre o que as instituições realmente decidiram no passado, que [...] o desacordo teórico é ilusório e mais bem compreendido como uma discussão não a respeito do que o direito é, mas a respeito do que ele deve ser (DWORKIN, 1985, p. 31). ${ }^{53}$

A incorporação do ponto de vista interno à teoria hartiana, no entanto, faz com que a atitude de aceitação em relação às regras - atitude que abarca tanto seu uso como um padrão de comportamento quanto como uma justificação para críticas dos desvios seja central para a identificação do direito. Isso implica a compreensão de que o direito está fundado em algo mais do que simples fatos históricos sobre as decisões tomadas pelas instituições jurídicas no passado. No positivismo de tipo hartiano, os "fundamentos do direito" residem na aceitação que se expressa no conteúdo da regra de reconhecimento, e não no conjunto de decisões que compuseram a instituição jurídica ao longo da história. Assim, a teoria de Hart não parece proscrever a possibilidade de desacordos teóricos: estes seriam desacordos sobre o que constitui a regra de reconhecimento, ou seja, sobre o objeto da atitude de aceitação ${ }^{54}$.

Dworkin, no entanto, argumenta que o positivismo jurídico é justamente a teoria que sustenta a abordagem do "mero fato", negando a existência de desacordos teóricos (DWORKIN, 1985, p. 37). Como ele pode elaborar essa crítica? O argumento dworkiniano não pode simplesmente atribuir a Hart uma caracterização do direito como um conjunto de fatos brutos, o que seria evidentemente falso.

De fato, Dworkin reconhece expressamente que este teórico rejeitou a ideia de que a autoridade do direito poderia ser explicada por fatos brutos de ordens e obediência habituais, e que ele formulou um positivismo mais "sofisticado" (Ibid., p. 40), segundo o qual os fundamentos do direito residem em uma atitude de aceitação dos participantes da prática social (Ibid., p. 34). Acredito que a chave para entender a crítica dworkiniana reside

\footnotetext{
${ }^{53}$ Tradução livre de "This holds that law depends only on matters of plain historical fact, that the only sensible disagreement about law is empirical disagreement about what legal institutions have actually decided in the past, that what I called theoretical disagreement is illusory and better understood as argument not about what law is but about what it should be."

${ }^{54}$ Nesse sentido, SHAPIRO, 2011, p. 285: "These Dworkinian distinctions, it should be noted, have analogues in Hart's theory of law. For example, the grounds of law are those facts set out in the rule of recognition. If the California rule of recognition states that all bills passed by a majority of both houses of the state legislature and signed by the governor are valid laws of California, then the facts of bicameral passage and executive signature are the grounds of law in the California legal system. Similarly, theoretical disagreements are simply disputes about the content of the rule of recognition, whereas empirical disagreements are disputes about whether the conditions set out in the rule of recognition have obtained in a particular case."
} 
neste segundo ponto: é a atitude de aceitação como uma descrição adequada da prática social jurídica que será desafiada pelo interpretativismo.

As teorias positivistas são denominadas por Dworkin teorias semânticas porque elas veem a si mesmas como tentativas de identificar o "significado" do conceito de direito (segundo Dworkin, esse é o caso de John Austin). A partir de uma perspectiva mais sofisticada de filosofia da linguagem, que afastou a plausibilidade de projetos definicionais em sentido estrito, as teorias passam a se ver não mais como tentativas estritamente de definição do conceito, mas como uma identificação de seus usos, que determinariam as circunstâncias nas quais as proposições jurídicas poderiam ser consideradas verdadeiras ou falsas. É dessa maneira que Dworkin caracteriza o projeto hartiano (Ibid., p. 32-33).

Como mostrado no primeiro capítulo, dificilmente é possível contestar essa descrição da teoria de Hart. Ele de fato construiu sua teoria a partir da identificação dos usos de determinados conceitos: além do próprio conceito de direito, também de outros relacionados, tais como obrigação e regra. No entanto, a caracterização da teoria semântica não está relacionada apenas com sua inclusão do grupo de teorias que realizam análise conceitual. Teorias semânticas, segundo Dworkin, "supõem que juristas e juízes usam basicamente os mesmos critérios (ainda que estes estejam escondidos e não sejam reconhecidos) ao decidir quando proposições jurídicas são verdadeiras ou falsas; elas supõem que os juristas na verdade concordam sobre os fundamentos do direito" (DWORKIN, 1986, p. 33, grifos acrescentados). ${ }^{55}$

É importante notar que, no argumento dworkiniano, a primeira característica da teoria semântica implica a segunda: a análise conceitual tal como realizada por Hart visa um esclarecimento dos usos conceituais de maneira a esclarecer quais situações são evidentemente abarcadas pelo conceito. É claro que pode haver situações pouco claras, como nas áreas de textura aberta, mas a análise hartiana tem a pretensão de revelar pelo menos os casos centrais do uso, pois tais casos possibilitariam captar o entendimento correto do conceito. Essa forma de realizar a teoria pressupõe a existência de um conjunto de critérios compartilhados aos quais os falantes se referem, pelo menos nos casos centrais. Seriam esses critérios que forneceriam o critério de verdade das proposições.

No caso de Hart, os critérios uniformemente compartilhados são aqueles da regra de reconhecimento, que se manifestam no uso desta regra para identificar o direito

\footnotetext{
${ }^{55}$ Tradução livre de "[Semantic theories] suppose that lawyers and judges use mainly the same criteria (though these are hidden and unrecognized) in deciding when propositions of law are true or false; they suppose that lawyers actually agree about the grounds of law."
} 
válido $^{56}$. A regra de reconhecimento não é, em si, válida nem inválida, porque ela é o próprio padrão de validade; assim como o metro-padrão de Paris, que nos mostra "o que é" um metro, a regra de reconhecimento também mostra o que é o direito. Não faz sentido dizer que o metro-padrão tem um metro, assim como não faz sentido dizer que a regra de reconhecimento é válida (HART, 1997, p. 109).

Neste modelo, as proposições de direito seriam verdade "em virtude de convenções sociais que representam a aceitação da comunidade de um esquema de regras que empodera certos grupos e pessoas como criadores de direito válido" (DWORKIN, 1985, p. 34, grifos acrescentados). ${ }^{57}$ Para Hart, o desacordo teórico, então, seria explicável apenas em termos de confusão conceitual. Quando há discordância sobre o que pode atribuir verdade a uma proposição jurídica, cada uma das partes está, na verdade, usando uma versão diferente da regra de reconhecimento.

A divergência, segundo esse tipo de teoria, seria parecida com uma divergência verbal a respeito de casos pouco claros sobre o uso de palavras na linguagem comum. Por exemplo, há regras compartilhadas que governam o uso do conceito de "arte". Concordamos que existem instâncias claras do que chamamos arte, tais como um quadro de Picasso e uma escultura de Rodin. Nos casos que saem desse "núcleo de concordância" - que se expressa na convergência de comportamentos que reconhecem determinadas instâncias do conceito -, não há regras compartilhadas que permitam atribuir verdade a uma ou outra proposição. Podemos discutir se fotografia é arte, mas essa controvérsia seria apenas uma questão de como decidimos proceder nos casos de penumbra, estipulando conceitos por "conveniência ou facilidade de exposição". Não existiria, segundo a compreensão hartiana, um debate genuíno sobre a fotografia realmente ser uma forma de arte (DWORKIN, 1985, p. 42). No direito, esses casos de fronteira, situados fora do núcleo de concordância, seriam os casos difíceis, nos quais o juiz possuiria discricionariedade para aplicar o direito da forma que julga mais adequada.

Dworkin argumenta, entretanto, que essa diferença entre casos centrais e casos de fronteira não é adequada. Isso porque, ao usar determinados tipos de conceitos, as pessoas discordam sobre os "testes" corretos para aplicá-los em qualquer situação, não só em casos de fronteira. No exemplo da controvérsia sobre fotografia, o debate pode ser a respeito do

\footnotetext{
${ }^{56}$ Para o positivismo jurídico, proposições jurídicas verdadeiras são aqueles que se refrem ao direito válido.

${ }^{57}$ Tradução livre de "[So propositions of law are true not just in virtue of the commands of people who are habitually obeyed, but more fundamentally] in virtue of social conventions that represent the community's acceptance of a scheme of rules empowering such people or groups to create valid law."
} 
que o próprio conceito de arte exige: um lado pode afirmar que a fotografia é um exemplo central de arte, e que quem pensa de outra maneira entende mal a natureza essencial da arte, enquanto o outro lado pode sustentar justamente o contrário, afirmando que as técnicas usadas pela fotografia contrariam os próprios objetivos da arte. Este é um tipo de controvérsia muito diferente daquela na qual as partes concordam sobre alguns casos centrais, e discordam apenas na maneira pela qual os casos de fronteira se diferenciam ou não dos centrais. (DWORKIN, 1985, p. 42)

$\mathrm{O}$ argumento do desacordo teórico no direito nos mostra que pelo menos parte das divergências que ocorrem na prática jurídica (talvez a maioria delas) são a respeito de casos centrais. E tais divergências ocorrem justamente porque não há concordância sobre o que constituem os "fundamentos do direito". O projeto das teorias semânticas, de encontrar as regras compartilhadas no uso dos conceitos, não tem meios, portanto, de ser bem sucedido: ele procura por algo que não está lá.

É apenas após a formulação deste argumento, que parte da constatação empírica dos desacordos teóricos para criticar o projeto de determinados tipos de teoria, que Dworkin formula a hipótese do ferrão semântico. É interessante notar que o ferrão semântico é apenas isso: uma hipótese sobre por que o positivismo não consegue explicar as práticas jurídicas sem distorcê-las em um tipo de prática convergente que não corresponde ao que elas de fato são.

\subsection{O ferrão semântico como uma "hipótese explicativa" e possíveis defesas do positivismo}

Dworkin afirma que as teorias semânticas sofrem de um "bloqueio" que as leva a insistir em uma descrição da prática jurídica segundo a qual existem regras compartilhadas para usar o conceito de direito. Esse "bloqueio" se dá em razão da suposição de que "as pessoas podem discutir de forma sensata se, e apenas se, nós todos aceitarmos e seguirmos os mesmos critérios para decidir quando nossas alegações são fundamentadas, mesmo que não possamos determinar exatamente, da maneira como um filósofo pode esperar fazer, quais são esses critérios.” (DWORKIN, 1985, p. 45).

Tal suposição é a armadilha criada pelo o que o autor denominou de "ferrão semântico". Trata-se de uma maneira de explicar porque o positivismo analítico se transformou em uma teoria que caracteriza a prática jurídica como uma prática convergente na identificação dos casos claros, de maneira evidentemente contrária ao 
mostrado pela observação empírica das discordâncias no direito. Segundo essa explicação, a análise conceitual realizada por Hart, ao adotar uma visão de compartilhamento dos conceitos baseada na existência de critérios comuns que explicam os usos ordinários dos conceitos, teria resultado em uma abordagem distorcida do fenômeno jurídico.

Essa caracterização da teoria de Hart é extremamente controversa, e há várias linhas de defesa do positivismo contra o argumento do ferrão semântico. Há autores que negam que Hart tenha construído uma teoria semântica (ENDICOTT, 1998; RODRIGUEZ-BLANCO, 2003), enquanto outros afirmam que, mesmo havendo uma semântica criterial com a qual ele tenha se comprometido, disso não decorreriam as dificuldades apontadas por Dworkin para explicar as divergências teóricas, pois estas poderiam decorrer, por exemplo, do desacordo na aplicação dos critérios compartilhados (RAZ, 1998; COLEMAN, 2002) ${ }^{58}$.

A primeira linha de defesa sustenta que Hart não afirmou a necessidade de seguir sua teoria para usar a palavra "direito" corretamente, e também nunca alegou que as pessoas de fato compartilham a visão de que os aspectos centrais que ele identifica no direito podem ser critérios para a aplicação da palavra. Diante dessa defesa, alguém poderia, ainda assim, afirmar que Hart produz uma teoria semântica: sua ideia de que uma comunidade que possui direito tem uma regra de reconhecimento - uma regra social que provê os critérios de validade jurídica - seria um indício daquela teoria. A tréplica a esse argumento afirma que Hart não associa os critérios de validade ao significado da palavra direito - este significado não é dado pelo conjunto de critérios que visam identificar o direito válido. Não existiria nada de semântico nos critérios de validade jurídica (ENDICOTT, --, p. 6). ${ }^{59}$

\footnotetext{
${ }^{58}$ Há ainda outra possibilidade de defesa do positivismo contra o argumento do ferrão semântico, que não será abordada aqui. Essa defesa afirma que, ainda que tenhamos que rejeitar a explicação criterial do conceito de direito, isso não significa que a única alternativa seja o interpretativismo proposto por Dworkin. Haveria outras possibilidades de explicação conceitual que não se comprometeriam nem com o criterialismo nem com o interpretativismo. COLEMAN \& SIMCHEN ( Law) abordam tanto a segunda quanto esta terceira linha de defesa. Sobre a segunda linha, afirmam: "Setting aside the fairness of attributing criterialism to positivism, the fact is that even were positivism committed to criterialism, this would render positivism neither semantic jurisprudence nor vulnerable to the semantic sting. For criterialism about meaning does not entail that two lawyers (or anyone else) employing different criteria for 'law' must disagree about the criteria of legality in their community. Nor is criterialism, properly or sympathetically understood, vulnerable to the semantic sting. To be so vulnerable, criterialism would have to imply that two lawyers who disagree about the grounds of law must be employing different extension-fixing criteria for 'law'." (COLEMAN \& SIMCHEN, Law, p. 7-8)

59 A discussão neste ponto remete à questão a respeito do tipo de análise conceitual que Hart pretendeu realizar, ambiciosa ou modesta (cf. Capítulo I). Uma forma de caracterizar a análise conceitual hartiana como ambiciosa é afirmar que ele supôs que o mero uso dos conceitos nos revela o entendimento correto desses conceitos (STAVROPOULOS, 2001). Nessa perspectiva, Hart estaria comprometido com a realização de uma teoria semântica no sentido mais próprio do termo, pois seu objetivo seria elucidar o significado correto
} 
A segunda linha de defesa afirma que, mesmo que o positivismo analítico não tenha estado preocupado em sustentar uma teoria do significado da palavra "direito" (como afirma a primeira defesa), isso não significaria que o argumento do ferrão semântico poderia ser desacartado. Este argumento poderia se aplicar às explicações criteriais do conceito de direito, ainda que estas explicações não sejam abordagens semânticas ${ }^{60}$ (RAZ, 1998, p. 59).

Nessa perspectiva, o argumento dworkiniano seria um argumento contra explicações criteriais do conceito de direito - a existência de desacordos teóricos a respeito de casos centrais do conceito mostraria a inadequação de teorias que sustentam a existência de critérios compartilhados para explicá-lo. Mas, de acordo com a segunda linha de defesa, Dworkin não deixa claro porque não poderia haver explicações criteriais a respeito de conceitos sobre os quais efetivamente existe desacordo teórico. Para afirmar que tais explicações não seriam adequadas, Dworkin precisaria sustentar que o criterialismo supõe que todos os usuários competentes do conceito concordam nos critérios de sua aplicação nos casos centrais. O criterialismo, no entanto, não está comprometido com uma tese desse tipo (RAZ, 1998, p. 61-62).

Essa última linha de defesa foi assumida por importantes representantes do positivismo analítico contemporâneo, sendo Joseh Raz o mais relevante destes. Raz fornece três argumentos $\operatorname{distintos}^{61}$ para sustentar que o criterialismo não está

das palavras referentes aos conceitos, revelando os critérios compartilhados no uso dessas palavras em casos centrais. Os autores que sustentam a primeira linha de defesa do positivismo precisam refutar que Hart tenha de fato tido essa ambição. Note que isso exige muito mais do que apenas afirmar que Hart não estava preocupado com o significado da palavra "direito". De fato, ele poderia ter pensado na sua teoria como uma análise dos usos compartilhados do conceito sem se preocupar com a implicação de que isso revelaria seu significado correto. Há passagens em $O$ Conceito de Direito) que permitem inferir que este seja o caso. No entanto, ao basear sua teoria na suposição de que o seguimento de regras pressupõe um acordo sobre o que as regras exigem, Hart parece atribuir um único significado correto às noções de obrigação ou de validade jurídica, por exemplo.

${ }^{60}$ Se entendermos semântica no sentido mais comum de explicação geral sobre o que faz a aplicação de determinada expressão ser correta (ENDICOTT, 1998, p. 3).

${ }^{61}$ Para entender o argumento raziano, é pertinente citar uma passagem na qual o autor sintetiza sua estratégia, após descrever o que entende ser o argumento adversário:

"Dworkin may be assuming that all competent users of a concept, which can be explained criterially, agree on its explanation, ie on the criteria for its correct application. On this assumption, when two people converse using a concept that can be criterially explained, then each of them uses the concept according to a set of criteria used by the other; and if they match, they are using the same concept annd cannot disagree regarding the criteria for its correct use, whereas if they do not match then they are using two different concepts and there is no disagreement between them.

$[\ldots]$

But why Dworkin think that [this] describes the situation which must obtain when people disagree about a criterion for the use of a concept that can be criterially explained? Dworkin never explains why he believes that concepts capable of being explained criterially land one in this situation. I will explain how once one avoids three possible mistakes it becomes plain that the argument fails. First, it is not the case that believing 
comprometido com a tese de que os usuários competentes do conceito precisam concordar sobre os critérios de sua aplicação nos casos centrais.

O primeiro argumento afirma a possibilidade de desacordo sobre o uso dos critérios porque estes são compartilhados de forma não individualista. Isso significa que existem regras compartilhadas sobre o uso dos critérios e falantes competentes podem cometer erros na aplicação dessas regras. Nas palavras de Raz, "Criterial explanations are explanations in terms of rules setting the criteria for the correct use of concepts, or words and there is nothing individualistic in that - which are the correct rules if they are shared by the linguistic community" (RAZ, 1998, p. 65). Esse primeiro argumento sustenta a possibilidade de desacordos sobre o uso dos critérios, mas nega que esses desacordos possam ser teoricamente interessantes (Ibid., p. 67). Afinal, o desacordo pode ser resultado do mero erro de um dos falantes.

Dois outros argumentos são necessários para mostrar a possibilidade de desacordos teoricamente interessantes sobre conceitos criterialmente compartilhados. $\mathrm{O}$ primeiro é o que poderíamos chamar de "argumento da complexidade e não transparência". Esse argumento sustenta que as regras compartilhadas sobre o uso dos conceitos são complexas a ponto de não ser possível fornecer uma explicação exaustiva sobre essas regras. Além disso, elas não são completamente transparentes para os usuários dos conceitos, de forrma que estes podem discordar sobre quais são as regras corretas (Ibid., p. 67-71).

O segundo argumento é o da "relativa interdependência dos conceitos interrelacionados", segundo o qual, ainda que, ao explicar determinados conceitos, devamos recorrer a outros conceitos relacionados, isso não significa a necessidade de termos um entendimento completo destes conceitos relacionados para entender o conceito principal. Assim, por exemplo, posso entender o conceito de "Estado justo" mesmo que esse conceito inclua, por exemplo, a noção de "boa vida" (uma possível definição de Estado justo seria "aquele que torna altamente provável que seus habitantes tenham uma boa vida"). Que não seja possível esclarecer o que é a "boa vida" por meio de explicações criteriais, não significa que o conceito de "Estado justo" não possa receber uma explicação criterial, a qual inclui no conceito o requisito de proporcionar uma boa vida. (Ibid., p. 7174)

of a concept that it is susceptible to a criterial explanation commits one to an individualistic explanation of it. Second, one needs to be aware of the diversity of criteria dor the correct use of concepts and of their possible opacity. And finally, one needs to remember that criterial explanations of concepts differ somewhat from other criterial explanation.” (RAZ, 1998, p. 61-62) 
Independentemente da correção desses argumentos e sua pertinência para refutar a crítica dworkiniana (o que será discutido brevemente abaixo), acredito que esse debate em torno do caráter linguístico do argumento do ferrão semântico não tem grande importância para a discussão do argumento do desacordo teórico. O "ferrão" foi oferecido por Dworkin apenas como uma hipótese ${ }^{62}$ para explicar o "bloqueio" das teorias semânticas, que seriam incapazes de explicar a prática jurídica sem transformá-la em uma prática convergente, distorcendo, assim, seu verdadeiro caráter. Segundo essa hipótese, tais teorias assumem uma tese de filosofia da linguagem segundo a qual a divergência genuína ${ }^{63}$ só pode se dar quando "nós todos aceitarmos e seguirmos os mesmos critérios para decidir quando nossas alegações são fundamentadas" (DWORKIN, 1985, p. 45). Essa tese levaria os positivistas a crerem que, nas disputas jurídicas nas quais não há uma base de critérios compartilhados, não há divergências reais sobre o que é o direito, mas apenas um falso desacordo que deverá ser solucionado com a decisão discricionária mais conveniente.

No entanto, mesmo que o positivismo negue ser uma teoria semântica (primeira linha de defesa), ou que ele defenda uma teoria semântica mais sofisticada, na qual é possível haver divergências verdadeiras e teoricamente interessantes mesmo que se assuma a existência de critérios comuns de compartilhamento dos conceitos (segunda linha de defesa), o "bloqueio" - ou seja, a insistência em explicar a prática jurídica como uma prática convergente - não terá se dissipado. Uma breve análise das duas linhas de defesa deixa isso claro.

A primeira linha assume que não existe uma teoria semântica por trás da ambição hartiana de explicar o direito em termos de regras sociais. Mas mesmo essa linha assume que há um mínimo de semântica com a qual Hart precisa se comprometer ${ }^{64}$ : ele afirmou que existem sistemas jurídicos "paradigmáticos" e é justamente o "paradigma" de sistema jurídico que sua teoria pretende identificar (ENDICOTT, 1998, p. 7). A defesa proposta por essa linha - a negação de existência de uma teoria semântica em Hart - consiste em

62 A apresentação do argumento do ferrão semântico como um argumento diverso do argumento do desacordo teórico foi feita por SHAPIRO, 2007, p. 38, nota 58, e p. 41, nota 59. Este autor, um positivista, acredita que o argumento do desacordo teórico é a mais importante crítica feita por Dworkin ao positivismo, e que as teorias positivistas, de maneira geral, não conseguiram superá-lo. Seu mais recente livro, Legality (SHAPIRO, 2012) é uma tentativa nesse sentido.

${ }^{63}$ Uma divergência é verdadeira quando os falantes compartilham um solo comum sobre o qual podem divergir. Se duas pessoas discordam sobre quantos bancos existem ao longo do Rio Tietê, por exemplo, elas precisam concordam em que tipo de banco estão falando: se agências bancárias ou bancos de areia. Caso os falantes tenham uma discussão em que um deles use a primeira acepção da palavra e o outro, a segunda, eles não estarão tendo um desacordo genuíno, pois estarão falando de coisas diferentes.

${ }^{64}$ De fato, como pretendi mostrar no primeiro capítulo da dissertação, seria muito difícil afirmar que Hart não esteve comprometido com nenhum tipo de semântica. 
afirmar que a alegação da existência de paradigmas não significa que as pessoas precisem se remeter a esse paradigma para usar corretamente o conceito de direito, nem que elas precisem de fato compartilhar o paradigma: "tudo o que Hart afirma que as pessoas compartilham em relação a um conceito como direito é a habilidade de identificar 'exemplos de direito' e a ideia de que existem diferentes sistemas jurídicos em diferentes países, e uma habilidade de identificar pontos salientes de similaridade entre sistemas jurídicos" (ENDICOTT, 1998, p. 8) ${ }^{65}$.

Esse argumento pode servir para afirmar que Hart não pretendeu fornecer uma explicação do direito por meio de critérios que precisam ser compartilhados pelas pessoas, mas não afasta o "bloqueio". A explicação do fenômeno jurídico permanece uma explicação em termos de uma prática convergente. A própria ideia de que existe um "paradigma indisputável" do conceito de direito sugere que existe uma instância única à qual as pessoas recorrem na identificação do direito, mesmo que não percebam estar fazendo isso, ou que o paradigma não seja completamente transparente para elas. Que a afirmação do direito em termos de paradigma não implique a existência de uma "teoria semântica" passa então a ser irrelevante para refutar o argumento de Dworkin.

Já a segunda linha de defesa é mais complexa. Estritamente falando, ela não nega a tese semântica que Dworkin atribui aos positivistas de maneira a explicar o "bloqueio". $\mathrm{Na}$ verdade, a segunda linha defende a tese semântica contra a ideia de que tal tese implicaria a incapacidade das teorias positivistas de explicar a existência de desacordos teóricos. Em outras palavras, enquanto a primeira linha de defesa do positivismo afirma que este não esteve comprometido com nenhum tipo de teoria semântica, a segunda linha concede a existência desse tipo de teoria no positivismo, mas afirma que ela não traz problemas à explicação dos desacordos teóricos.

Essa linha de defesa afirma corretamente não ser suficiente, para refutar o argumento do "ferrão semântico", a demonstração de que Hart não esteve comprometido com a realização de uma teoria semântica. Isso porque o argumento é uma forma de ataque às explicações criteriais dos conceitos, algo que de fato está presente em $O$ Conceito de Direito.

\footnotetext{
${ }^{65}$ Tradução livre de "[So] all that Hart claims that people share concerning a concept like law is the ability to identify 'examples of law', and the idea that there are different legal systems in different countries, and an ability to identify salient points of similarity among legal systems."
} 
Como exposto acima, a estratégia dessa defesa do positivismo é argumentar por uma teoria semântica mais sofisticada, na qual é possível haver divergências genuínas e teoricamente interessantes mesmo que existam critérios comuns de compartilhamento dos conceitos. A defesa parece direcionada a afirmar tão somente que conceitos compartilhados de forma criterial podem suscitar divergências ${ }^{66}$. É preciso lembrar, no entanto, que Dworkin não nega a possibilidade de haver divergências sobre conceitos criteriais. Isso ocorre nos chamados "casos de fronteira", nos quais os critérios de compartilhamento dos conceitos não são tão claros. De fato, é justamente este o argumento que o positivista levanta para explicar os "casos difíceis" no direito sem abrir mão da ideia de que existem critérios compartilhados no uso do conceito.

$\mathrm{O}$ argumento do desacordo teórico, no entanto, visa justamente negar que a explicação por meio da ideia de "casos de fronteira" seja uma boa explicação. O desacordo teórico no direito se dá a respeito de casos centrais, e, na verdade, nem seria claro porque deveríamos diferenciar entre casos centrais e casos de fronteira. Devemos relembrar o exemplo do desacordo sobre fotografia ser ou não uma forma de arte: para entender essa divergência, é preciso considerar que cada uma das partes tem uma concepção diferente a respeito de arte. Esta é a raiz de sua discordância, que não se explica por uma aplicação diferente, feita por cada uma das partes, dos critérios de identificação do conceito de arte para o caso da fotografia.

\footnotetext{
${ }^{66}$ Dale Smith fornece um argumento semelhante a este para defender a ideia de que Raz não conseguiu refutar o argumento do ferrão semântico. Ele afirma que os três argumentos de Raz - não individualismo, complexidade e opacidade dos critérios, e relativa independência dos conceitos inter-relacionados - são suficientes para refutar o que ele denomina "versão forte" do ferrão semântico, mas não uma versão mais fraca, que seria a versão com a qual Dworkin estaria comprometido. A versão forte afirmaria que explicações criteriais do conceito de direito não seriam suficientes para explicar nenhum desacordo teórico sobre o direito. A versão fraca afirma que as explicações criteriais do conceito de direito não são suficientes para explicar todos os desacordos teóricos sobre o direito que surgem, ou podem surgir, na prática (SMITH, 2009, p. 304). Smith afirma que Raz não consegue refutar a versão fraca: "while the non-individualistic picture and the argument from complexity can account for some theoretical disagreements on the basis that one or more parties to the dispute are mistaken, Raz cannot allow for widespread error regarding the criteria for the application of the concept of law, since he claims that the correct criteria are those that are generally believed to be correct. This suggests that, while Raz's arguments can account for some theoretical disagreements, it is unlikely that - even when considered together-they can account for the quantity and diversity of theoretical disagreement that Dworkin claims to exist." (Ibid., p. 318) O argumento de Smith é interessante, mas acredito que a diferenciação feita por ele entre a versão forte e fraca do ferrão semântico não se sustenta. Para Dworkin, todos os desacordos teóricos são insuscetíveis de explicações criteriais. Assim, Raz poderia explicar alguns tipos de divergências (não desacordos teóricos) que poderiam surgir ao usarmos conceitos criteriais, mas não os desacordos que surgem no direito, que são teóricos. Acredito que o argumento de Smith pode ser reinterpretado de forma a afirmar que Raz entende erroneamente o ferrão semântico como um argumento que afirma a impossibilidade de teorias semânticas criteriais explicarem desacordos. Se esse fosse o argumento, então Raz o teria refutado. Mas, como pretendei deixar claro no texto, não é esta a alegação de Dworkin.
} 
Assim, fica claro que a segunda defesa do positivismo não se livra do "bloqueio"; na verdade, ela o aprofunda, ao afirmar que existe, sim, uma semântica criterial capaz de explicar o conceito de direito. A existência de uma semântica desse tipo nos levaria a supor, ao contrário das evidências fornecidas pela prática, que há, sim, critérios compartilhados de forma profunda - talvez de forma tão profunda que nenhum falante consiga acessá-los, de maneira que eles nem seriam realmente critérios.

O que toda essa discussão acerca dos contra-argumentos ao "ferrão semântico" nos mostra? Acredito que ela nos mostra apenas que Dworkin foi infeliz ao usar a palavra "semântica" para denominar o argumento, trazendo à tona toda uma gama de questões complexas de filosofia da linguagem que não são estritamente necessárias para entender sua crítica.

A verdadeira crítica ao positivismo reside, a meu ver, na sua incapacidade de ver o direito como uma prática de controvérsias profundas, as quais não dizem respeito a discordâncias na aplicação de critérios ou a maneiras equivocadas de comparar casos reais com paradigmas. O "bloqueio" do positivista não se afasta por meio da negação de que ele esteja fazendo uma teoria semântica, ou por meio da defesa de teorias semânticas mais sofisticadas.

Tal "bloqueio" é, na verdade (e ironicamente, considerando que se trata da teoria "herdeira" da tradição hartiana), um bloqueio do ponto de vista interno: ele se expressa na negação de entender a prática a partir da perspectiva de seus participantes. É isso que impede o positivista de enxergar os desacordos teóricos. Para esclarecer esse ponto, será necessário apresentar o segundo momento do argumento de Dworkin, no qual, uma vez constatada a necessidade de dar conta dos desacordos teóricos na prática jurídica, será preciso entender, em primeiro lugar, qual o caráter da prática que torna tais desacordos possíveis e, em segundo lugar, de que maneira o teórico pode explicar a prática e seus desacordos.

\section{Práticas interpretativas e o papel do teórico}

O que torna o desacordo teórico possível? Para que haja uma divergência genuína quando as pessoas discordam sobre os fundamentos do direito, elas precisam compartilhar pelo menos uma base mínima de acordo. Do contrário, estariam apenas falando de coisas diferentes. Seria como, em uma discussão sobre em que medida precedentes judiciais devem ser respeitados, um debatedor falasse da perspectiva do direito inglês e outro, do 
direito alemão. Suponha que, por algum motivo, eles achassem que estavam se referindo ao mesmo sistema jurídico. Os debatedores poderiam discutir infinitamente, mas sua divergência seria apenas uma confusão, e não um desacordo teórico genuíno.

Para entender o que torna esses desacordos possíveis, é preciso entender em que contexto eles ocorrem. É claro que não são todos os conceitos que são suscetíveis a desacordos desse tipo. Dificilmente poderíamos discordar sobre o que fundamenta o uso do conceito de água, por exemplo. O fundamento de uma frase como "A água é composta por moléculas de $\mathrm{H} 2 \mathrm{O}$ " é a própria natureza da água, sua estrutura real. Da mesma maneira, ao dizermos "Um homem sem nenhum fio de cabelo é careca", estamos nos referindo à forma pela qual convencionamos denominar essa característica humana.

Mas existem conceitos para os quais teorias que revelam estruturas naturais ou critérios compartilhados não são suficientes. Tais teorias não suficientes quando

membros de comunidades específicas que compartilham práticas e tradições fazem e disputam alegações sobre qual é a melhor interpretação dessas práticas e tradições - quando eles discordam sobre o que alguma tradição ou prática realmente requer nas circunstâncias concretas. Essas alegações são frequentemente controversas, e o desacordo é genuíno mesmo que as pessoas usem diferentes critérios na formação ou estruturação dessas interpretações; ele é genuíno porque as interpretações em competição são direcionadas aos mesmos objetos ou eventos de interpretação. (DWORKIN, 1986, p. 46) ${ }^{67}$

Essa é a caracterização das práticas nas quais o conceito em jogo é um conceito interpretativo. Entendê-las é essencial para captar o argumento de Dworkin acerca da metodologia adequada para a teoria do direito.

\subsection{Práticas interpretativas: o que são e quando surgem}

Assim como Hart, Dworkin caracteriza as práticas que são objeto de seu estudo a partir do ponto de vista dos seus participantes. Para se caracterizarem, as práticas interpretativas requerem uma determinada atitude de seus participantes. Mas, ao contrário das práticas jurídicas para Hart, a atitude requerida não é de aceitação de regras.

\footnotetext{
${ }^{67}$ Tradução livre de "[It does not hold] when members of particular communities who share practices and traditions make and dispute claims about the best interpretation of these-when they disagree, that is, about what some tradition or practice actually requires in concrete circumstances. These claims are often controversial, and the disagreement is genuine even though people use different criteria in forming or framing these interpretations; it is genuine because the competing interpretations are directed toward the same objects or events of interpretation."
} 
O primeiro requisito da atitude interpretativa é que as pessoas precisam enxergar um propósito ou sentido ("point") na prática. Esse propósito pode ser acessado de maneira independente da caracterização de todas as regras que constituem a prática (Ibid., 1986, p. 47). Assim, não são práticas interpretativas aquelas nas quais o seguimento de regras existe por si, como simples hábito, sem qualquer atribuição de sentido a ele relacionado.

Como Hart já havia mostrado (e Weber antes dele), as pessoas tomam parte de uma prática ao adotar o sentido da prática como o sentido de suas próprias ações. Práticas sem qualquer sentido ao qual uma ação humana possa se referir se assemelham mais a eventos naturais, tais como chuvas de verão nos finais das tardes de janeiro. Podemos em certa medida prever esses eventos, mas eles não têm um sentido ou propósito (não se excluirmos interpretações místicas ou religiosas) que possa ser explicado.

É significativo, entretanto, que Dworkin tenha usado a palavra "point" (e não purpose, por exemplo) para se referir a essa primeira característica da atitude interpretativa. Acredito que o uso da palavra se dá porque a identificação do sentido tem que ser feita do ponto de vista do participante: é ele quem tem que ver um sentido na prática. Assim, o point traz a ideia daquilo ao que a prática se direciona - o seu "ponto" que apenas aparece para quem dela participa.

Um operário que aperta parafusos em uma linha de produção, por exemplo, frequentemente perde de vista o sentido de suas ações e as realiza mecanicamente, sem qualquer reflexão. Do ponto de vista do operário, a prática se assemelha então a práticas que existem por tabu, como o uso de ordálias para acusar alguém de um crime (e. g., "se ela afundar, é uma bruxa”). Ainda que a sua prática e a de seus colegas tenha um sentido que pode ser descrito de uma perspectiva externa, a atitude do operário não será interpretativa se ele mesmo não enxergar a prática como sendo direcionada a algo, mesmo que dessa atitude resulte a conclusão de que ela realmente não tem nenhum sentido, e, assim, não é uma prática valiosa.

A ideia de valor, portanto, por vezes usada para traduzir "point", está relacionada a este conceito, mas de uma maneira indireta. A identificação do point é a atitude que busca o valor da prática, mas essa atitude não precisa necessariamente resultar em algum valor. Nesses casos em que nada de valioso resulta, a atitude interpretativa não reconhece as regras da prática como regras vinculantes. É o caso - para lembrar o exemplo com o qual Dworkin conclui “Modelo de Regras II" e que é retomado em "O Império do Direito" - de práticas de cortesia do homem para com a mulher. Regras que compõem essa prática, 
tais como "o homem é obrigado a pagar o jantar", não são regras para quem, guiado por uma atitude minimamente feminista, não enxerga valor na prática.

Esse exemplo mostra que a atitude interpretativa é, acima de tudo, crítica. Ela pode considerar que prática tenha que ser modificada ou mesmo que ela tenha de cessar. À primeira característica da atitude interpretativa junta-se, assim, uma segunda, que é a suposição segundo a qual os requisitos da prática são sensíveis a seu point (DWORKIN, 1986, p. 47). Assim, o participante que adota a atitude interpretativa afirma que as regras da prática são "entendidas ou aplicadas ou estendidas ou modificadas ou qualificadas ou limitadas por aquele propósito (point)" (DWORKIN, 1986, p. 47). Essa segunda característica é peculiar a "práticas interpretativas em sentido estrito",68.

Jogos, por exemplo, são práticas interpretativas para as quais seus participantes identificam um propósito, e apelam a este quando afirmam ser necessária uma mudança de regras. No entanto, os participantes dos jogos não supõem que as regras sejam, em um momento atual, sensíveis ao propósito. Um exemplo interessante a esse respeito é a ideia de que jogos de futebol não devem ser decididos por pênaltis, pois isso não seria adequado ao propósito desse jogo, que envolve muita habilidade, estratégia e resistência para ser decidido por uma espécie de "loteria" na qual a sorte muitas vezes conta mais do que a aptidão técnica $^{69}$. Quem defende essa ideia, no entanto, não supõe que a regra atual exclua a cobrança de pênaltis. Se os pênaltis serão ou não decisivos, isso está relacionado uma questão de "história e convenção" (Ibid., p. 48): é o órgão que regula os jogos de cada campeonato quem decide como estes serão decididos. A interpretação desempenha, portanto, apenas um "papel externo" (Ibid., p. 48) em jogos e concursos.

Nas práticas interpretativas, ao contrário, a atitude interpretativa é aquela que identifica não só porque a prática existe - qual o seu propósito - mas também o que a prática requer em um momento atual. Assim, o valor e o conteúdo das práticas interpretativas estão emaranhados, pois a identificação de seu point adquire um potencial crítico.

O exemplo usado por Dworkin para mostrar como práticas interpretativas surgem e mudam é o das práticas de cortesia. Antes de haver uma atitude interpretativa (no

\footnotetext{
${ }^{68}$ Para usar uma expressão adotada por MACEDO JR, 2012, p. 162.

${ }^{69}$ Alguns comentaristas de fato defendem essa visão, criticando especialmente que as finais de Copa do Mundo possam ser decididas por pênaltis: "But it is hard not to regret the penalty kicks, too, and wonder how a game of enormous skill and endurance, a game defined by carefully constructed attacks, can be reduced to a relatively static, out-of-context lottery with the most important trophy in world sports at stake." (CLAREY, Cristopher. "Dreaming of an end to soccer's nightmare". New York Times, 12 de março de 2010. Disponível em: http://www.nytimes.com/2010/03/13/sports/soccer/13iht-ARENA.html?_r=1\&).
} 
"sentido estrito", com seus dois componentes), todos assumem que o propósito da cortesia reside na "oportunidade que ela provê para mostrar respeito por superiores". As pessoas não se questionam sobre se essas formas tradicionais de respeito são realmente aquelas requeridas pela prática. Mas, com o desenvolvimento da atitude interpretativa, o propósito adquire um "poder crítico", e as pessoas passam a demandar formas de deferência que antes eram desconhecidas ou recusar formas que anteriormente eram honradas. "A interpretação, então, volta-se à própria prática, alterando a sua forma, e a nova forma encoraja mais reinterpretação, então a prática muda dramaticamente, ainda que cada passo desse progresso seja interpretativo do que o último atingiu" (DWORKIN, 1986, p. 48$)^{70}$.

A cortesia pode mudar, por exemplo, a depender dos fundamentos que as pessoas consideram adequados para o respeito: se este deve ser direcionado a superiores, ou a pessoas mais velhas ou às mulheres. Ou ainda, pode haver o questionamento sobre se existe valor em um respeito que é direcionado a grupos específicos da sociedade ou a pessoas com determinadas características naturais, independentemente de suas conquistas individuais. Pode ser que esse último questionamento faça com que as pessoas passem a considerar como o propósito da cortesia algo quase oposto ao que era originalmente considerado, pois elas passam a valorizar formas impessoais de relação, para as quais não se requer nem se nega uma maior significação. Assim, pode ser que a cortesia passe a ocupar uma parte bem pequena da vida social, e que a atitude interpretativa se esvaia, fazendo com que a prática retorne ao estado mecânico e estático anterior ao desenvolvimento da atitude interpretativa (Ibid., p. 48-49).

Como se nota pelo exemplo da cortesia, a prática interpretativa não está fora da história: ela muda constantemente e se desenvolve de diferentes formas a depender de onde a atitude interpretativa crítica nos leva. Como identificar práticas interpretativas?

Muitas vezes se explica o caráter da prática interpretativa como sendo aquela prática na qual o conceito usado é um "conceito essencialmente contestado",71. Trata-se de uma formulação do filósofo W. B. Gallie, que se tornou clássica na filosofia das ciências sociais e a partir da qual também foi popularizada a distinção entre conceitos e concepções.

\footnotetext{
70 Tradução livre de "Interpretation folds back into the practice, altering its shape, and the new shape encourages further reinterpretation, so the practice changes dramatically, though each step in the progress is interpretive of what the last achieved".

${ }^{71}$ O próprio Dworkin já usou essa formulação em obras mais antigas (v. TRS, p. 103, 105, 107), mas ela não se repete com frequência em textos recentes, ainda que apareça no seu último livro (DWORKIN, 2011, p. 125), como veremos no último tópico desse capítulo.
} 
"Conceitos essencialmente contestados" são aqueles que preenchem cinco condições: (1) eles são "avaliadores" (appraisive), pois se referem a um tipo de empreendimento considerado valioso em algum sentido ou medida; (2) esse empreendimento deve ser internamente complexo; (3) qualquer explicação da importância ou valor do empreendimento deve se referir às respectivas contribuições de suas várias partes e características; (4) o empreendimento reconhecido dessa forma deve ser de tal tipo que admita modificações à luz de mudanças nas circustâncias; (5) cada parte que participa do empreendimento reconhece o fato de que seu próprio entendimento do conceito é contestado pelas outras partes. (GALLIE, 1956, p. 171-172).

O exemplo clássico de um conceito essencialmente contestado é o conceito de “justiça social"72: a respeito desse conceito, não é possível extrair uma definição conclusiva, mas apenas discutir as justificativas que cada parte pode ter para sustentar uma determinada concepção do conceito.

A caracterização dos conceitos essencialmente contestados é, realmente, muito próxima à caracterização de conceitos interpretativos. Mas considere um argumento positivista que busca defender a possibilidade de uma teoria neutra e puramente descritiva acerca do conceito de direito e, para tanto, refuta a ideia de que este seja um conceito essencialmente contestado - pois, se o direito for realmente um conceito desse tipo, então qualquer teoria sobre ele será uma concepção e, como tal, refutável, sujeita a revisões e avaliativa exatamente no sentido em que as concepções dos demais participantes do empreendimento o são.

Esse tipo de argumento positivista (MARMOR, 2005, p. 27) toma seguinte forma. A primeira condição que um conceito deve cumprir para que ele seja contestável é que ele seja um conceito "avaliador", ou seja, ele deve se referir a um tipo de empreendimento valioso, para o qual podemos dizer que existe mais ou menos do valor que o conceito expressa. Não há dúvidas de que o conceito de justiça, por exemplo, é um conceito essencialmente contestado. Mas o direito não é um conceito desse tipo, ao menos no aspecto considerado relevante para a teoria do direito, porque ele não é "avaliável". Segundo esse argumento, o foco da controvérsia entre positivistas e demais teóricos está no conceito e nas condições de validade jurídica - e a validade jurídica, ou o que poderíamos denominar "juridicidade" (legality), não é um empreendimento que alguém possa ter mais ou menos sucesso em realizar (como algo pode ser mais ou menos justo, mais ou menos

\footnotetext{
${ }^{72}$ Os outros exemplos fornecidos por Gallie são o de arte, de democracia, e de aderência, ou participação, em determinada religião (GALLIE, 1956, p. 180).
} 
artístico etc.). $\mathrm{O}$ bom direito é bom porque promove algum bem, não porque é mais ou menos "jurídico" (legal) ou mais ou menos "direito". A controvérsia está voltada à determinação do que o direito é, o que faz algumas normas serem direito válido - não há aí qualquer referência a um conceito essencialmente contestado.

Como podemos avaliar um argumento desse tipo? Ele discorda da classificação do conceito de direito como um conceito essencialmente contestado. As bases da discordância não estão, no entanto, em alguma característica "intrínseca" ao conceito, mas no contexto em que ele é usado. $\mathrm{O}$ argumento positivista afirma que, no sentido relevante para a teoria, o conceito de direito refere-se aos critérios de validade jurídica. Então, é nesta base que o argumento deve ser refutado, e não por referência a uma classificação conceitual a priori. Um contra-argumento poderia então afirmar que o positivista incorre em uma petição de princípio, pois ele precisaria mostrar que a teoria do direito não é, ela mesma, um empreendimento em busca do valor da "juridicidade".

Qualquer que seja a resposta a esse argumento, o que ele nos mostra é que o caráter da prática interpretativa não reside no compartilhamento de algum tipo conceitual, e não outro. O exemplo da cortesia nos mostra que a identificação da prática interpretativa é sociológica e histórica, e não puramente linguística. Que o conceito usado nessa prática seja um "conceito interpretativo" (ou "essencialmente contestado"), para o qual não estão disponíveis explicações semânticas (como veremos no próximo tópico), é resultado do desenvolvimento de determinada atitude dos participantes, que não é uma atitude linguística, mas uma atitude política de reflexão e crítica ${ }^{73}$. O caráter das nossas práticas linguísticas é apenas uma consequência dessa atitude.

\footnotetext{
${ }^{73}$ Para uma argumentação semelhante, no sentido de que Dworkin teria, no início de sua obra, atribuído muita importância ao caráter linguístico da prática interpretativa, mas depois teria passado a caracterizar essa prática em termos sociológicos, v. MOORE, 1988, p. 944: "When do we interpret this way? Early in his career, Dworkin seems to have thought that the justification for engaging in creative interpretation was linguistic in the sense that such interpretation was called for by the existence of 'essentially contested concepts'-concepts such as equality- that can be distinguished from other concepts simply by the way they are used within the linguistic community. If usage reveals an agreement about the meaning of a concepteither in the way it is defined or in what constitutes a paradigmatic exemplar of it-and if usage also reveals a pattern of systematic disagreement over the competing understandings of that concept, it is 'essentially contested'. Dworkin's more recent criteria for when creative interpretation is appropriate look sociological. Creative interpretation arises, Dworkin tells us, when a community 'develops a complex 'interpretive' atitude towards the rules' of some social practice like courtesy"” (grifos acrescentados).
} 


\subsection{A interpretação das práticas sociais e a indisponibilidade de teorias externas}

O próximo passo do argumento interpretativista é essencial para entendermos a metodologia dworkiniana. Ele consiste em responder à pergunta de como deve ser a interpretação das práticas sociais que são elas mesmas interpretativas. Dworkin irá afirmar que a interpretação da prática é um exercício da própria prática, apenas em um nível mais abstrato. Qualquer teoria da interpretação, oferecida de um nível ainda mais abstrato, será controversa como as interpretações mais concretas. Isso porque, se uma comunidade compartilha conceitos interpretativos, então o próprio conceito de interpretação será um deles: "uma teoria da interpretação é uma interpretação da prática de nível superior de usar conceitos interpretativos" (DWORKIN, 1986, p. 49) ${ }^{74}$.

\subsubsection{Qual interpretação na prática interpretativa?}

Para começarmos a entender esse argumento um tanto obscuro, é preciso, em primeiro lugar, distinguir entre alguns tipos de interpretação (DWORKIN, 1986, p. 50-53). Grande parte do nosso conhecimento é interpretativo, mas ele se diferencia a depender da característica da interpretação que é feita. Uma forma comum de interpretação é a conversacional, que consiste em atribuir sentido ao que diz um interlocutor com o qual interagimos. A interpretação científica é de outro tipo, e consiste em atribuir sentido a conjunto de dados reunidos pelo cientista.

A interpretação de certos objetos, como obras de arte ou práticas sociais, não parece se encaixar nesse esquema. Ela envolve atribuir sentido a algo criado por pessoas (portanto, não a eventos naturais, como na interpretação científica), mas que, ao contrário da fala que é objeto da interpretação conversacional, se destaca como uma obra distinta de seus autores. Como explica apropriadamente Scott Shapiro,

Obras de arte e práticas sociais são entidades distintas na medida em que seus criadores as produzem com a intenção de que suas crenças sobre o significado do trabalho dependam do significado do trabalho, e não o contrário. Os autores, em outras palavras, não consideram a si mesmos como autoridades sobre o significado de suas criações (SHAPIRO, 2012, p. 293, grifos acrescentados). ${ }^{75}$

\footnotetext{
74 Tradução livre de "[...] a theory of interpretation is an interpretation of the higher-order practice of using interpretive concepts".

75 Tradução livre de "Works of art and social practices are distinct entities in that their creators produce them with the intention that their beliefs about the meaning of the work should depend on the meaning of the work,
} 
Assim, ao ter como objetos de interpretação práticas sociais ou obras de arte, não temos à disposição um significado que pode ser encontrado "logo ali", que nos é revelado pelos dados ou pela intenção de quem fala. Esse tipo de interpretação, diferentemente das duas primeiras, é construtiva, no sentido de que ela envolve o propósito do próprio intérprete. $\mathrm{O}$ intérprete atribui sentido ao objeto interpretado por meio de uma interação entre seus próprios propósitos e o objeto, cuja história ou forma impõe certos limites às interpretações disponíveis (DWORKIN, 1986, p. 52). Ao impor seus propósitos, o intérprete busca revelar o objeto como o melhor representante do gênero ao qual se considera que o objeto pertence.

Essa ideia de interpretação criativa parece estranha à primeira vista, pois ela exige um tipo de interação entre intérprete e interpretando que não temos facilidade em admitir. Uma objeção poderia ser formulada no sentido de que seria mais apropriado entender a interpretação construtiva como um tipo de interpretação conversacional, na qual buscamos reconstruir a intenção dos autores - da prática social ou da obra de arte. Assim, evitaríamos a "estranha" postura de que o intérprete deve interagir com o que pretende interpretar, o que poderia "contaminar" o resultado final da interpretação com as visões do próprio intérprete, distorcendo o que de fato exige o interpretando.

Para discutir essa objeção, Dworkin a desenvolve em forma de uma teoria, que podemos denominar "teoria da intenção do autor" ou intencionalismo. O que a abordagem construtiva da interpretação nos dizia diferente dessa teoria? Ela nos pedia para considerar o que podemos denominar, para a interpretação de obras de arte, de "hipótese estética". Para textos literários, poderíamos formular assim essa hipótese: interpretar um texto não é nem achar um significado dado, que pode ser encontrado de plano na obra ("logo ali"), nem inventar algo completamente novo; a interpretação literária reside no meio desses dois extremos, e consiste em tentar mostrar o texto como a melhor obra de arte que ele pode ser. (DWORKIN, 2005).

Segundo Dworkin, há duas formas pelas quais podemos apreciar a teoria da intenção do autor. Ou ela não se opõe à hipótese estética, apresentando-se como uma melhor teoria da interpretação justamente no plano apresentado por essa hipótese (Ibid., p. 230-231). Ou, de uma maneira implausível, ela pretende considerar as intenções do autor

rather than the other way round. Authors do not, in other words, take themselves to have authority over the meaning of their creations." 
"em algum sentido estrito e restrito" na determinação do significado de uma obra, tomando como ponto central à interpretação o "estado de espírito" do autor. Neste caso, o intencionalismo ignora as complexidades desse estado, não sendo capaz de explicar, por exemplo, como o próprio autor pode enxergar sua própria obra de maneira diversa da que enxergava quando a escreveu ${ }^{76}$. Essa mudança de visão não é fruto de uma introspecção profunda, na qual o autor descobre em seu subconsciente a "verdadeira" intenção que tinha ao escrever sua obra, mas decorre de uma opinião interpretativa diferente por ele elaborada. Tais opiniões são variáveis (DWORKIN, 2005, p.231-233).

Assim, "se nós considerarmos que o objetivo da interpretação artística é descobrir a intenção do autor, isso será uma consequência de termos aplicado os métodos da interpretação construtiva à arte, não de termos rejeitado esses métodos" (DWORKIN, 1986 , p. 54, grifos no original). ${ }^{77}$

Como traduzir a analogia da interpretação artística para o direito, considerando-o uma prática interpretativa no mesmo sentido em que a interpretação artística o é? Podemos formular para a prática jurídica uma "hipótese política", que, de forma análoga à hipótese estética, afirma que a interpretação jurídica sempre tenta conferir maior coerência e integridade ao sistema. Da mesma maneira que a hipótese estética abre espaço para a teoria da interpretação do autor como uma melhor teoria da interpretação, também a hipótese política abre espaço para o intencionalismo, em uma visão que considere este parte fundamental de uma "melhor teoria política".

Para que consideremos, assim, no âmbito do direito, a teoria da intenção do autor como uma objeção à teoria desenvolvida como Dworkin (que podemos agora denominar “direito como interpretação”), precisamos compreender aquela teoria - de maneira análoga à ssegunda opção disponível ao intencionalismo literário quando confrontado com a hipótese estética - como uma proposta segundo a qual apenas intenções dos participantes da prática devam ser consideradas na interpretação do direito.

O intencionalismo insiste nesse ponto em nome da exigência de uma interpretação "neutra", na qual, de maneira análoga à atividade que realizamos na interpretação conversacional, não precisamos "comprometer" o resultado da interpretação com aquilo

\footnotetext{
${ }^{76}$ Confrontado com uma interpretação de sua obra que não estava originalmente em sua intenção, o autor pode experienciar um "choque de reconhecimento" (DWORKIN, 1986, p. 58), como se dissesse: "Era exatamente isso que eu estava fazendo!"

77 Tradução livre de "[...] if we do take the goal of artistic interpretation to be discovering an author's intention, this must be a consequence of having applied the methods of constructive interpretation to art, not of having rejected those methods."
} 
que nós achamos melhor ou mais apropriado ${ }^{78}$. Então, o intencionalista não pode defender que a interpretação da prática social é uma questão de recuperar as próprias intenções que ele mesmo (o intencionalista) possui ao participar da prática. Ele quer, na verdade, ver a prática de um ponto de Arquimedes, que possa garantir a ele o máximo de objetividade em sua interpretação.

Nesse caso, poderíamos oferecê-lo duas possibilidades: a primeira afirma que a interpretação da prática social deve significar descobrir propósitos ou intenções dos outros participantes da prática, a segunda afirma que a interpretação social deve descobrir o propósito da comunidade na qual a prática ocorre, concebendo essa comunidade como tendo alguma forma de "vida mental ou consciência de grupo" (DWORKIN, 1986, p. 63).

A primeira dessas sugestões parece mais plausível, pois não envolve nenhum tipo de personalização da comunidade. Mas como poderíamos proceder? Uma interpretação dos atos de todos os participantes, um por um, não seria o mesmo que ainterpretação da própria prática, que envolve algo que os participantes fazem coletivamente. A prática em si tem um significado diverso dos atos individuais de cada participante, e é a este significado (não ao significado de suas próprias atitudes) que os participantes se remetem ao fazer alegações e elaborar argumentos sobre a prática.

Essa diferença entre as intenções dos participantes e as intenções das práticas, entre o significado do que eles fazem individualmente e do que é feito coletivamente, seria desimportante se assumíssemos que as práticas sociais são uniformes, ou seja, se todos os participantes concordassem na melhor maneira de interpretá-las (DWORKIN, 1986, p. 63). Mas essa concordância não existe; na verdade, a prática floresce como uma prática interpretativa justamente porque algum tipo de divergência se instaura.

Os métodos de interpretação conversacional não estão, assim, disponíveis ao participante. Ao tentar decidir o que a prática requer, ele direciona sua interpretação não aos que os outros membros da comunidade acreditam serem os requisitos da prática, mas ao que ele mesmo entende serem tais requisitos. Percebemos, portanto, que, mesmo se aceitássemos a segunda sugestão acima proposta, que afirma a existência de uma atitude intencional da própria comunidade onde ocorre a prática, não seria possível nos desvencilhar da nossa própria perspectiva. A "vida mental" da comunidade apenas adicionaria mais uma opinião à prática a ser interpretada, a "consciência de grupo" é algo

\footnotetext{
${ }^{78}$ É interessante notar que a hermenêutica weberiana e, em algum sentido, também a de Hart, envolvem interpretações conversacionais, buscando assim excluir o propósito dos intérpretes ao realizar a interpretação (MACEDO JR., 2012, p. 107-108)
} 
distinto do que o próprio participante-intérprete enxerga como os requisitos da prática. (Ibid., p. 65-66)

\subsubsection{O teórico da prática: conceitos e concepções, paradigmas, adequação e valor}

Essa maneira de enxergar as possibilidades de interpretação disponíveis aos participantes também se coloca para o próprio cientista social. Ele pode escolher fazer um relatório neutro e descompromissado sobre o que os diversos participantes da prática pensam que ela requer. Isso, no entanto, não corresponde a uma interpretação da prática ela mesma. Caso queira assumir esse segundo projeto, o cientista social não tem outra opção senão adotar os métodos que os próprios participantes usam para definir o que a prática requer. Assim, ele deve se juntar à prática, ainda que apenas como um participante "virtual" (DWORKIN, 1986, nota 14), pois somente assim poderá fornecer uma abordagem da prática ela mesma, algo mais do que o mero relatório do que cada um dos participantes pensa sobre ela. As conclusões a que o cientista chega estarão, assim, em competição com as conclusões interpretativas dos próprios participantes. (Ibid., p. 64)

Podemos ilustrar a posição do teórico retomando o exemplo da cortesia. Suponha que a comunidade na qual a prática floresceu gostaria de ter uma ideia mais clara sobre a natureza da cortesia, então os cidadãos "encomendam" a um filósofo uma "teoria conceitual sobre a natureza da cortesia" (Ibid., p. 68). Eles não desejam que o filósofo ofereça, de seu ponto de vista pessoal, uma avaliação sobre o que a cortesia é. Eles não desejam suas visões substantivas porque elas teriam tanto interesse quanto as visões de cada um dos participantes. Os cidadãos da cortesia querem, ao contrário, o que realmente a cortesia requer, em virtude da sua própria natureza.

Que alternativas o teórico possui? Ele é como um "homem no Pólo Norte ao qual se diz para ir a qualquer lugar menos pro sul" (Ibid., p. 69). Qualquer tentativa que ele fizesse para tentar extrair regras semânticas da palavra "cortesia", ou para oferecer os "casos centrais" nos quais dizemos existir cortesia, já estaria violando os requerimentos dos participantes que o contrataram. Essas tentativas resultariam em visões "substantivas" exatamente do tipo que foi vetado ao filósofo. Ele poderia dizer que "tirar o chapéu para um nobre" faz parte da definição de cortesia, é um caso claro de sua ocorrência. Mas sua visão estaria em direta competição com a dos participantes da prática, e muitos destes poderiam simplesmente discordar que essa ação constitui um gesto de cortesia. 
O teórico poderia então, recorrer a uma estratégia mais abstrata, que não se coloca fora da prática interpretativa, mas também não está exatamente no mesmo nível no qual as pessoas discordam acerca de suas visões substantivas. Ele pode tentar oferecer uma abordagem do conceito sobre o qual as pessoas discordam de maneira a tentar captar sobre $o$ que elas estão discordando. No caso da cortesia, por exemplo, o teórico poderia interpretar o conceito disputado como algo que está associado a respeito - e as pessoas divergem a partir das diferentes visões que tem sobre o respeito e o que ele exige, adotando assim diferentes concepções sobre o conceito de cortesia. Dessa maneira, o teórico impõe uma estrutura à divergência. A ligação "conceitual" que ele aponta entre cortesia e respeito não é, apesar de abstrata, uma ligação semântica. Ela é, em algum sentido, incontroversa, pois supõe que o teórico tenha tido sucesso em captar um sentido comum compartilhado na prática. No entanto, a visão que ela expressa é historicamente localizada - depende de como a prática se desenvolve naquele momento e pode se alterar a qualquer tempo - e é plenamente contestável, ao contrário de afirmações plenamente semânticas como " $O s$ Miseráveis é um livro e não um panfleto". (DWORKIN, 1986, p. 70-72) Quem contestar essa visão mais abstrata fornecida pelo teórico será visto como defensor de uma teoria mais heterodoxa, mas sua afirmação não será um nonsense, apenas um sinal de que a divergência na prática se aprofundou.

Uma segunda tarefa que o teórico da cortesia pode pretender cumprir é identificar os chamados paradigmas da prática. Estes são situações concretas que servem para a comunidade como exemplos centrais do que a prática exige, como uma situação à qual qualquer interpretação da prática deve se ajustar. Nesse sentido, eles servem como uma "âncora" para a interpretação. Mas, assim como uma abordagem abstrata do conceito interpretativo, o paradigma não está imune às divergências e contestações da prática. Pode ser que esta se altere de maneira que uma situação que já foi paradigmática passe a ser considerada um erro. (Ibid., p. 72)

O exemplo dado por Dworkin é esclarecedor: em determinado momento da prática de cortesia, um paradigma importante foi a regra de que homens devem se levantar quando mulheres entram em um recinto. Mas veio um momento em que as mulheres começaram a considerar isso um profundo desrespeito, nesse sentido, uma descortesia. Então o que era o "paradigma de ontem" transformou-se no "chauvinismo de hoje". (Ibid., p. 73)

Essa transformação de paradigmas revela que a interpretação da prática não procura apenas se adequar ao que a prática é, de forma concreta, em determinado 
momento. Essa dimensão da adequação é, claro, muito importante, pois as pessoas precisam ter convicções em alguma medida convergentes sobre o que é adequado à prática para que se diga que elas compartilham a mesma prática ${ }^{79}$.

Mas, para que se diga que os participantes realmente adotam uma atitude interpretativa em relação à prática, é preciso que eles considerem ainda uma segunda dimensão, diversa da dimensão da adequação. Essa dimensão se expressa nas convicções substantivas adotadas pelos participantes sobre que tipos de justificativa poderiam colocar a prática em sua melhor luz Tais convicções não precisam ter o grau de compartilhamento entre os participantes que têm as convicções sobre a adequação, mas são, em alguma medida, limitadas por estas. (DWORKIN, 1986, p. 67-68) Trata-se aqui da dimensão do valor da interpretação, que é a dimensão na qual as mudanças ou rupturas da prática começam a se formar.

As dimensões de adequação e valor são parte de um mesmo juízo avaliativo, porque não devem levar a conclusões opostas ou diversas: elas constituem uma opinião única sobre qual interpretação faz da prática o melhor que ela pode ser (DWORKIN, 1986, p. 411). Assim, não existe um trade-off entre adequação e valor, e nem aquela funciona como a dimensão que constitui um "patamar mínimo" do que é reconhecido pela prática. Qualquer interpretação leva em conta, ao mesmo tempo, ambas as dimensões.

\subsubsection{A interpretação no direito: o "prólogo silencioso"}

Como já tinha ficado claro na equiparação do direito à literatura ao se discutir a teoria intencionalista, a prática da cortesia é uma alegoria da prática jurídica. Dworkin afirma que equiparar o direito à cortesia é mais proveitoso que compará-lo à justiça, por exemplo (ainda que justiça também seja um conceito interpretativo), pois a cortesia tem um caráter de prática local que não é próprio às práticas interpretativas em torno da justiça. Uma teoria da justiça terá um requisito de adequação mais "frouxo" que qualquer teoria do direito, pois dela não se requer, da maneira como se requer da teoria jurídica, que se adéque às práticas políticas ou sociais de qualquer comunidade específica. (DWORKIN, 1986, p. 424-425, nota 20)

O caráter local da prática jurídica implica a existência de "fatores socializantes e unificantes" que contribuem para que a prática seja em grande parte convergente apesar

79 "Once again, there cannot be too great a disparity in different people's convictions about fit; but only history can teach us how much difference is too much.” (DWORKIN, 1986, p. 67) 
das convicções diversas de seus participantes. (DWORKIN, 1986, p. 88) Esses fatores se expressam em paradigmas abstratos do tipo "A legislação infraconstitucional faz parte do direito", mas também em outras características sociológicas da prática em cada local, tais como a força dos precedentes ou da legislação, a existência de uma comunidade jurídica que compartilha experiências e limita a ação de seus membros, o caráter conservador da educação jurídica formal.

Não podemos ignorar esses fatores de unificação, mas também não podemos exagerar sua força. Eles não são capazes de tornar o direito uma prática estática, como a cortesia antes da adoção de uma atitude interpretativa, até mesmo porque a própria identificação de práticas - tais como os fatores de unificação - que contam como práticas jurídicas é uma questão interpretativa. Não há "uma definição compartilhada e intelectualmente satisfatória do que um sistema jurídico é e o que necessariamente o compõe" (DWORKIN, 1986, p. 91$)^{80}$.

Assim, a questão sobre em que medida um sistema jurídico converge e em que medida não há suficiente acordo para se dizer que uma prática interpretativa pode se instaurar não pode ser respondida de fora da própria prática. Os limites desta não são definidos de forma pré-interpretativa, pois o debate real ocorre quando as pessoas já estão participando da prática, elas não precisam de um "guia" para entrar (RIPSTEIN, 2007, p. 13). Esse acordo pré-interpretativo necessário à instauração da prática é, ademais, "contingente e local", não há uma convenção "mundial" e "eterna" de juristas a respeito de quais práticas contam como práticas jurídicas (DWORKIN, 1986, p. 91).

Esse cenário nos mostra que os teóricos do direito estão na mesma posição dos teóricos da cortesia: não existem regras, critérios ou fundamentos comuns para se identificar fatos jurídicos. Não identificamos nem mesmo instituições jurídicas dessa maneira. Então, qualquer teoria do direito será, como a teoria da cortesia, uma interpretação construtiva: "elas tentam mostrar a prática como um todo em sua melhor luz, tentam atingir um equilíbrio entre a prática jurídica como ela se encontra e a melhor justificação dessa prática" (Ibid., p. 90, grifos acrescentados) ${ }^{81}$.

A questão central da controvérsia em torno da metodologia proposta por Dworkin para a teoria do direito reside na ideia de "melhor justificação". Há uma incompreensão

\footnotetext{
${ }^{80}$ Tradução livre de "[It would be a mistake - another lingering infection from the semantic sting - to think that we identify these institutions through some] shared and intellectually satisfying definition of what a legal system necessarily is and what institutions necessarily make it up".

${ }^{81}$ Tradução livre de "they try to show legal practice as a whole in its best light, to achieve equilibrium between legal practice as they find it and the best justification of that practice".
} 
comum segundo a qual o interpretativismo é uma mistura de descrição dos fatos da prática com a realização de julgamentos morais (GUEST, 2005, p. 5).

A proposta de Dworkin ${ }^{82}$, no entanto, não é fazer uma "teoria mista". Ela consiste em chamar atenção para o fato de que o direito é uma prática normativa e argumentativa ${ }^{83}$, que só é adequadamente entendida por meio de avaliação ${ }^{84}$. O erro de Hart teria sido considerar que a normatividade poderia ser explicada apenas por referência a uma atitude de conformidade dos participantes às regras. A ideia de prática interpretativa nos mostra que não é o caso. Mais que normativa, a prática é argumentativa, o que significa dizer que as pessoas discordam sobre o que o valor expresso nessa prática exige (ou, em um desacordo mais profundo, elas divergem até mesmo sobre a existência de algum valor na prática).

Assim, qualquer teoria do direito é uma avaliação da prática jurídica, porque é somente assim que se descobre o que é o direito. É esse o fundamento de um argumento dworkiniano que causará perplexidade entre os demais teóricos: o de que não existe uma firme linha divisória entre a teoria e a adjudicação. O teórico entende o direito como o juiz o faz para aplicá-lo no caso concreto: avaliando a prática. A teoria jurídica é, portanto, a "parte geral da adjudicação, o prólogo silencioso a qualquer decisão ${ }^{85}$ no direito" (DWORKIN, 1986, p. 90).

\footnotetext{
${ }^{82}$ Trata-se de uma proposta contínua, que se inicia desde o argumento do "Modelo de Regras II", no qual se revela a inexistência de regras compartilhadas que possam explicar os desacordos teóricos, e se aperfeiçoa em $O$ Império do Direito, no qual a ideia de direito como prática interpretativa se desenvolve em toda a sua integralidade.

${ }^{83}$ Andrew Halpin expõe corretamente as características do interpretativismo para Dworkin: "Any rigorous and intelligible account of Dworkin's theory of law and its associated methodology must be sensitive to the different elements it contains. For Dworkin in Law's Empire the practice of law possesses six features (which legal theory and its associated methodology are bound to reflect). Law is: (1) normative; (2) argumentative; (3) interpretive; and, moreover, (4) constructively interpretive. Law, also, (5) justifies state coercion; and (6) displays integrity. The ease with which Dworkin himself moves between one feature and another is perhaps the biggest obstacle to constructing a coherent account of his position. Nevertheless, a failure to acknowledge each of these features, and work out the relationships between them, only makes matters worse. I have already indicated the importance of recognising (2) alongside (1), in providing an accurate account of Dworkin's methodology. By neglecting (2), H.L.A. Hart in his posthumous Postscript, The Concept of Law, 2nd ed. by Penelope A. Bulloch \& Joseph Raz (Oxford: Clarendon Press, 1994) at 241- 44, can more easily reach the conclusion (at 244) that, 'Description may still be description, even when what is described is an evaluation.' True it is that one can describe what has been evaluated, without engaging in evaluation, but one cannot describe what will be the outcome of that which is still open to argument. And it is difficult to see how one can in such circumstances even make a suggestion about the outcome without engaging in the argument. If the argument in question is a normative one then the move from descriptive to normative work is complete." (HALPIN, 2006, p. 96)

${ }^{84}$ Stephen Guest faz um argumento semelhante, ao afirmar a impossibilidade de ver a prática interpretativa a não ser pelas lentes da moral, pois os "fatos" da prática só estão lá em razão do seu status moral. (GUEST, 2005, p. 5).

${ }^{85}$ É importante notar que Dworkin usa a figura do juiz como elemento central em O Império do Direito porque se trata de uma figura para quem a necessidade de saber o que é o direito aparece de forma mais
} 


\section{Estamos todos interpretando?}

A ideia de que a teoria hartiana não conseguiu fornecer uma abordagem completa sobre a normatividade do fenômeno jurídico, pois não explicou como o direito é capaz de fornecer razões para agir, é aceita até mesmo entre positivistas ${ }^{86}$, que buscaram adequar o positivismo para abarcar esse desafio. Um ponto central, no entanto, permanece firme como uma divisão marcante entre teorias positivistas e o interpretativismo de Dworkin: trata-se da ideia de que o teórico deve, ele mesmo, avaliar a prática de maneira a entender o direito.

Neste tópico, pretendo expor uma importante proposta nesse sentido, como contraposição e crítica à proposta dworkiniana. A partir dessa exposição, será possível acessar os argumentos de obras recentes de Dworkin, que foram oferecidos, em grande medida, como respostas a esses novos desenvolvimentos do positivismo contemporâneo.

\subsection{Natureza e conteúdo do direito: o desafio raziano}

Joseph Raz é provavelmente o positivista contemporâneo de maior notoriedade. Sua teoria é conhecida como uma teoria da autoridade no direito - é por meio desse conceito que ele pretende explicar o surgimento das razões para agir daqueles que se submetem a uma ordem jurídica. Mantendo o foco no objeto desta dissertação, a exposição de sua teoria estará voltada muito mais para suas posições metodológicas do que para as suas teorias substantivas, mas estas são mencionadas sempre que pertinente.

\subsubsection{Três maneiras de entender a natureza do direito}

Raz distingue três maneiras de entender a natureza do direito: a abordagem linguística, a "perspectiva do jurista” e a abordagem institucional.

pujante e concreta. Mas não podemos esquecer que todas as outras figuras que compõem a prática jurídica (o legislador, o promotor, o advogado etc.) também realizam a interpretação construtiva que é o procedimento necessário para se tomar qualquer decisão no direito.

${ }^{86} \mathrm{E}$ a tese de que qualquer teoria do direito deve tratar da normatividade de fenômeno também é amplamente difundida. Para uma abordagem em sentido contrário, trazendo argumentos diversos dos colocados pelos positivistas contemporâneos, v. ENOCH, 2011. 
A única destas três sujeita ao argumento dworkiniano seria a abordagem linguística (RAZ, 1995, p. 195-198). Segundo tal abordagem, a questão sobre a natureza do direito seria uma tentativa de definir o significado da palavra "direito". Essa forma de investigar a natureza do direito foi incentivada pelo antiessencialismo que caracterizou a filosofia analítica moderna, mas suas deficiências fazem com que seja alvo de inúmeras críticas pelos filósofos contemporâneos.

Um primeiro problema é a multiplicidade de usos da palavra "lei" (law), mesmo em contextos não jurídicos. $\mathrm{O}$ teórico que pretende realizar uma abordagem linguística poderia partir da suposição de que todos os usos são relacionados, de forma parasitária, a um significado central, que é aquele que o filósofo do direito busca elucidar. No entanto, Raz aponta corretamente que essa suposição é equivocada ${ }^{87}$, por dois motivos distintos. Em primeiro lugar, porque não existem razões para assumir que o discurso sobre leis teóricas (como o discurso sobre "leis da natureza", por exemplo) possui qualquer relação com o discurso sobre leis práticas, dentre as quais se inclui o direito. Em segundo lugar, porque não há fundamentos para se dizer que as regras jurídicas constituem o significado central da palavra "lei", tendo assim preeminência dentre as leis práticas, que abarcam também, por exemplo, leis morais.

A abordagem linguística poderia ser direcionada a outras palavras, como "jurídico" ou "juridicamente", mas essa mudança também não resultaria em uma investigação frutífera, pois (i) não é sempre que essas palavras figuram em sentenças juridicamente relevantes (v.g., "eles fizeram um contrato") e, além disso, (ii) "juridicamente" ou "jurídico" podem ser usadas em associação com outros tipos de direito, como o direito canônico, por exemplo, e, assim, não terem qualquer relação com as afirmações jurídicas no sentido relevante que pretendemos investigar. Em suma, a abordagem linguística sofre, segundo Raz, de uma confusão entre filosofia e lexicografia.

Um segundo tipo de abordagem para elucidar a natureza do direito seria o que Raz denomina de "perspectiva do jurista". Esta aceita sem questionamentos uma "intuição básica" segundo a qual "O direito tem a ver com aquelas alegações que são consideradas apropriadas ao raciocínio das cortes na justificativa de suas decisões” (RAZ, 1995, p. 199). Ainda que essa intuição seja o ponto de partida dessa segunda abordagem, seria possível aceitá-la sem se comprometer com a "perspectiva do jurista".

${ }^{87}$ Segundo Raz, John Austin, contra quem Hart direcionou sua teoria, seria culpado de tal suposição. 
Segundo Raz, Dworkin seria o maior exemplo de uma tradição da teoria do direito norte-americana segundo a qual o direito é apenas o que as cortes fazem: ele teria desenvolvido uma teoria da adjudicação e a considerado, sem maiores reflexões, uma teoria do direito. Essa ligação entre as duas teorias parece muito natural da "perspectiva do jurista”, que não vê razão para ir além da suposição de que o direito tem a ver com o raciocínio jurídico. Nessa perspectiva, uma teoria como a de Dworkin é mais bem acabada que a teoria de Kelsen, por exemplo, que, apesar de ter aceitado a "intuição básica", não se empenhou em dar uma explicação de por que algumas considerações usadas pelas cortes não são jurídicas, mas morais (enquanto, para Dworkin, estas últimas também constituem o direito).

A plausibilidade da "perspectiva do jurista" como uma instância metodológica apropriada é questionada por Raz a partir da seguinte questão: por que devemos estudar as instituições apenas da perspectiva do jurista? Ele afirma:

O direito é de interesse de todos os que estudam a sociedade em geral, e a filosofia jurídica, especialmente quando investiga a natureza do direito, deve se afastar da perspectiva do jurista, não para desconsiderá-la, mas para examinar juristas e tribunais em sua devida localização na perspectiva maior da organização social e política das instituições em geral. (RAZ, 1995, p. 204)

Assim, para dar conta desse aspecto do direito como uma instituição, que interage com outras instituições na sociedade, e é relevante não apenas para os juristas, uma "abordagem institucional" seria mais apropriada do que as duas acima descritas.

A abordagem institucional aceita a "intuição básica" como um ponto de partida, mas a qualifica atribuindo algumas características aos tribunais. Em primeiro lugar, seria preciso considerar que tribunais lidam com disputas de maneira a resolvê-las. Em segundo lugar, eles emitem regras "autoritativas" ao decidir essas disputas, ou seja, regras que pretendem ter uma autoridade peremptória (“serem autoritativas ${ }^{89, ") . ~ E s s a ~ p r e t e n s a ̃ o ~ n a ̃ o ~}$

\footnotetext{
${ }^{88}$ Tradução livre de "The law is of interest to students of society generally, and legal philosophy, especially when it inquires into the nature of law, must, stand back from the lawyer's perspective, not in order to disregard it, but in order to examine lawyers and courts in their location in the wider perspective of social organization and political institutions generally."

${ }^{89}$ A palavra não tem uma correspondência clara na língua portuguesa. Traduções incluem "estar autorizado" ou "ser oficial"; autoritário ou dominante; e ainda, impositivo ou peremptório. Esta última tradução parece ser a mais adequada, revelando a característica da autoridade como aquilo que termina discussões, que se impõe não permitindo dúvidas subsequentes, ou seja, de forma categórica e terminante. Segundo Raz, "What distinguishes authoritative directives is their special peremptory status" (RAZ, 1995, p. 212). Peremptório, entretanto, não é uma palavra imediatamente associada à ideia de autoridade. Assim, por não haver uma palavra que denote exatamente "aquilo que põe termo a uma discussão por meio de um ato de autoridade", optei pelo uso do neologismo "autoritativo" - que tem exatamente o significado daquilo que alega ter
} 
precisa ter qualquer fundamento moral, uma vez que o mero fato de uma opinião (uma resolução para o caso) ser emitida pelo tribunal faz dela uma razão. Em terceiro lugar, os tribunais, nas suas atividades, tendem a ser guiados ao menos parcialmente por "considerações positivistas dotadas de autoridade", considerações que podem ser afirmadas sem recurso a argumentos morais. Segundo Raz, "Não é possível haver uma corte de direito a menos que ela considere autoritativos alguns parâmetros positivistas, como o costume, a legislação ou precedente" (Ibid., 206).

Cada uma das três maneiras de abordar o direito nos traria uma condição que deve ser respeitada por aqueles que pretendem teorizar sobre sua natureza. A abordagem linguística afirma a condição linguística: "Todas as proposições jurídicas podem ser afirmadas por meio da fórmula "juridicamente p"”. A "visão do jurista" adiciona a essa condição a "intuição básica". A abordagem institucional, por sua vez, estabelece mais um limite a uma teoria sobre a natureza do direito: "O direito consiste apenas em considerações positivistas autoritativas".

Para chegar a essa conclusão, Raz afirma que as instituições políticas operariam em dois estágios: um deliberativo e outro executivo. No primeiro, qualquer questão está aberta a discussões e a considerações de caráter variado, sendo que razões de natureza moral frequentemente irão predominar. Mas, uma vez que a questão é resolvida de maneira satisfatória para a instituição social envolvida, esta irá emitir uma instrução autoritativa, que é a conclusão do estágio deliberativo e pertence já ao estágio executivo - assim, essa instrução não será identificada por meio de argumentos morais, que pertencem, por definição, ao estágio deliberativo.

Isso sugere que o direito consiste de considerações autoritativas positivistas vinculantes para as corte e pertence essencialmente ao estágio executivo da instituição política da qual é parte (o estado, a igreja, etc.). O que resulta disso é que as cortes aplicam ambas considerações jurídicas (i.e. considerações autoritativas positivistas) e não jurídicas. Elas se fiam em razões executivas e deliberativas, mas o direito pertence apenas ao primeiro tipo. $\left(\mathrm{RAZ}, 1995\right.$, p. 207) ${ }^{90}$

autoridade peremptória (ser autoritativo). Importante notar que o próprio Raz usa a ideia de "autoritativo" como uma abreviação de "aquilo que alega ser autoritativo" (Ibid., p. 205).

${ }^{90}$ Tradução livre de 'This suggests that the law consists of the authoritative positivist considerations binding on the courts and belongs essentially to the executive stage of the political institution (the state, the church, etc.) of which it is a part. The resulting picture has the courts applying both legal (i.e. authoritative positivist) and non-legal considerations. They rely both on executive and deliberative reasons, yet the law belongs to the first kind only." 
O fato de considerações deliberativas permanecerem à disposição das cortes não é, segundo Raz, um problema para a teoria, assim como também não é algo a ser moralmente condenado. Isso porque é bom que as considerações do estágio executivo sejam mais gerais, de forma a fixar um quadro mais amplo dentro do qual as cortes podem aplicar diferentes razões deliberativas ${ }^{91}$. Esta, de qualquer maneira, é uma questão de política legislativa, que não concerne propriamente à natureza do direito. Ainda que as cortes apliquem considerações não jurídicas, que pertencem mais apropriadamente ao estágio deliberativo, isso não muda o caráter do direito como consistindo de “considerações positivistas autoritativas que são aplicadas pelas cortes” (Ibid., 208).

Diante desse cenário, podemos perceber que, para Raz, uma teoria da adjudicação é claramente moral, pois deve levar em conta todas as considerações jurídicas e não jurídicas que estão à disposição das cortes: ao separar quais são as considerações não jurídicas que devem ser aplicadas e qual a força que essas considerações devem ter, uma teoria da adjudicação estará obviamente formulando um raciocínio moral. Se a teoria do direito pudesse ser identificada com a teoria da adjudicação, então também a teoria do direito será também moral.

A abordagem institucional raziana, entretanto, sugere uma visão diferente. O direito, enquanto instituição social, pertenceria ao estágio executivo, podendo ser identificado sem que seja necessário recorrer a argumentos morais. Assim, a tarefa de uma teoria sobre a natureza do direito é fornecer esse teste para sua identificação, teste este que não requer o recurso à moral ou a qualquer argumento avaliativo. É importante notar, no entanto, que Raz afirma claramente que qualquer teoria sobre a natureza do direito não pode ser defendida sem que se usem argumentos avaliativos (ainda que não necessariamente morais). Isso por que "sua justificação [da teoria] está ligada a um julgamento avaliativo sobre a importância relativa de várias características das organizações sociais, e estas refletem nossas preocupações e interesses morais e intelectuais" (RAZ, 1995, p. 209) ${ }^{92}$.

\footnotetext{
${ }^{91}$ Interessante notar que esse argumento é muito parecido com o argumento de Hart sobre a textura aberta das regras, que também afirma a existência de uma "vantagem moral" na sua vagueza (v. Capítulo I).

${ }^{92}$ Tradução livre de "[The doctrine of the nature of law yields a test for identifying law the use of which requires no resort to moral or any other evaluative argument. But it does not follow that one can defend the doctrine of the nature of law itself without using evaluative (though not necessarily moral) arguments.]] Its justification is tied to an evaluative judgment about the relative importance of various features of social organizations, and these reflect our moral and intellectual interests and concerns."
} 


\subsubsection{Autoridade e a "tese da coerência"}

É justamente esse teste para identificar o direito sem recurso à moral ou a outros argumentos avaliativos que Raz pretende fornecer com a sua teoria da autoridade. Expor essa teoria será útil para entendermos em que bases Raz sustenta a chamada "tese das fontes" 93 e recusa o que ele denomina "tese da coerência"94, tese esta atribuída a Dworkin.

A teoria da autoridade em Raz está baseada em três teses que o autor formula da seguinte maneira (RAZ, 1995, p. 214):

A primeira é a tese da dependência, segundo a qual as diretivas autoritativas devem ser baseadas, entre outros fatores, em "razões dependentes". Razões dependentes são aquelas que se aplicam àqueles que se submetem às diretivas e que se sustentam nas circunstâncias abarcadas pelas diretivas. Ou seja, elas são dependentes da situação à qual se dirige a diretiva.

A segunda tese é chamada de tese da justificação normal. Essa tese afirma que a maneira normal e primária pela qual se reconhece que uma pessoa tem autoridade sobre outra envolve a demonstração de que aquele que se submete à autoridade provavelmente conseguirá cumprir melhor com as razões que se aplicam a ele (razões outras que não as alegadas diretivas autoritativas) se ele aceitar as diretivas da alegada autoridade como autoritativamente vinculantes, e tentar seguir essas razões, ao invés de tentar seguir as razões que se aplicam a ele diretamente. Essa tese estabelece então, que há uma vantagem para quem se sujeita à autoridade: essa pessoa tem mais chance de, por meio da autoridade, seguir razões que se aplicariam a ela de qualquer forma.

Por fim, a terceira tese é chamada tese da "exclusividade" (pre-emption): o fato de que uma autoridade requer que determinada ação seja realizada é uma razão para que ela seja realizada, razão esta que não se adiciona a todas as outras razões relevantes que se colocam quando nos perguntamos o que fazer, sim as substitui. A tese da exclusividade, portanto, afirma que autoridade fornece razões que substituem as razões que uma pessoa normalmente tem para agir.

A primeira e a segunda tese formam o que Raz denomina de "concepção de serviço da autoridade". Por essa concepção, autoridades fornecem uma mediação entre as pessoas e as razões corretas que devem se aplicar a elas. (RAZ, 1995, p. 214)

\footnotetext{
93 A tese das fontes afirma que todo direito é baseado em fontes. (RAZ, 1995, p. 210)

${ }^{94}$ A tese da coerência afirma que o direito consiste no direito baseado em fontes mais a melhor justificação moral do direito baseado em fontes. (RAZ, 1995, p. 211)
} 
A concepção de serviço implica que aquele que emite as diretivas somente tem autoridade se suas diretivas são autoritativamente vinculantes porque ele as fez. Isso tem duas consequências. Em primeiro lugar, uma diretiva pode ser autoritativamente vinculante apenas se ela é, ou pelo menos se apresenta como sendo, a visão de X sobre como as pessoas que estão submetidas a X devem se comportar. Em segundo lugar, deve ser possível identificar a diretiva como sendo emitida pela autoridade sem se basear em considerações ou razões as quais a diretiva se propõe a adjudicar. ${ }^{95}$ (Ibid., p. 218)

O direito, segundo Raz, alega ter autoridade legítima. Mesmo que ele realmente não tenha essa autoridade, ele deve ser capaz de tê-la. Assim, ele deve ser, ou pelo menos se apresentar como sendo, a visão de alguém sobre o que as pessoas submetidas a ele devem fazer, e deve poder ser identificado de maneira independente das considerações sobre as quais a autoridade deve decidir. As fontes jurídicas (legislação, precedentes e costumes), afirma Raz, cumprem essas duas condições (RAZ, 1995, p. 220-1)

Como essa construção pode servir para refutar a teoria dworkiniana?

Raz atribui a Dworkin duas ideias centrais (Ibid., p. 222-225). Em primeiro lugar, a ideia de que todas as decisões judiciais são baseadas em uma moralidade política e que o juiz expressa uma posição moral ao decidir os casos. Se entendida de uma forma atenuada, como atribuindo ao juiz a crença de que existe uma doutrina válida (possivelmente moral) que pode basear sua decisão, então Raz concordaria com essa ideia. A segunda ideia atribuída a Dworkin, no entanto, parece a Raz completamente equivocada. Trata-se da ideia de que os juízes têm o dever de respeitar e expandir a moralidade política de seu país. Esse dever, de respeitar a lei e seu espírito, seria aplicável a qualquer sistema jurídico de qualquer país, simplesmente por se tratar de um sistema jurídico ${ }^{96}$.

\footnotetext{
${ }^{95}$ Raz fornece o seguinte exemplo para ilustrar essa situação: "Suppose that an arbitrator, asked to decide what is fair in a situation, has given a correct decision. That is, suppose there is only one fair outcome, and it was picked out by the arbitrator. Suppose that the parties to the dispute are told only that about his decision, i.e. that he gave the only correct decision. They will feel that they know little more of what the decision is than they did before. They were given a uniquely identifying description of the decision and yet it is an entirely unhelpful description! If they could agree on what was fair they would not have needed the arbitrator in the first place. A decision is serviceable only if it can be identified by means other than the considerations the weight and outcome of which it was meant to settle. [...] They can benefit by its decisions only if they can establish their existence and content in ways which do not depend on raising the very same issues which the authority is there to settle." (RAZ, 1995, p. 219)

${ }^{96}$ Segundo Raz, isso imporia a um juiz da África do Sul sob o regime de apartheid o dever de expandir essa discriminação. A ideia de que os juízes tem o dever de expandir a moralidade política de seu país certamente não pode ser atribuída a Dworkin, e decorre de uma interpretação equivocada da ideia de direito como integridade, que ainda não estava inteiramente formulada nos textos nos quais Raz se baseia para a crítica, notadamente "Casos Difíceis". De qualquer maneira, acredito não é necessário dar tanta importância para esse equívoco, uma vez que a intenção é discutir a maneira pela qual Raz enxerga as tarefas da teoria do direito, em oposição à maneira como o próprio Dworkin as enxerga.
} 
A teoria do direito de Dworkin é caracterizada por Raz como uma defesa da "tese da coerência", segundo a qual o direito consiste em tudo o que emana das fontes jurídicas mais a melhor justificação moral que possa ser oferecida para esse material.

Essa teoria violaria, assim, as duas características necessárias que Raz atribui ao direito. Em primeiro lugar, não reconheceria que diretivas jurídicas são autoritativas, ou seja, que elas são, ou pelo menos se apresentam como sendo, um julgamento sobre o que aqueles submetidos à autoridade devem fazer. Para Dworkin, a melhores justificativas das diretivas emanadas das fontes jurídicas também compõem o direito, assim, este abarca conteúdo que pode nunca ter sido pensado, muito menos expresso, na forma de julgamentos sobre o que é recomendável fazer. Em segundo lugar, estaria evidente que a maneira proposta por Dworkin para identificar o que é o direito supõe que sejam novamente consideradas as questões que o direito, na concepção raziana, se propõe a resolver.

A divergência de Raz é explicitamente uma divergência sobre o papel da teoria: o pressuposto desse autor é que a teoria do direito deve oferecer uma abordagem sobre a natureza do fenômeno jurídico que forneça um teste capaz de identificar o direito sem recurso a moral ou a outros argumentos avaliativos. É interessante notar que Raz atribui a "tese da coerência" a Dworkin a partir de uma citação na qual este busca explicar como é possível estabelecer o conteúdo do direito em determinado país, não a natureza do direito $\operatorname{comotal}^{97}$.

Na verdade, é possível supor, em primeiro lugar, que Dworkin não acredita que o direito possua uma "natureza" no sentido mais próprio do termo, e, em segundo lugar, que qualquer tentativa de determinar seu conteúdo está baseada em uma abordagem mais geral sobre o que ele é.

Para Raz, no entanto, a separação entre natureza e conteúdo do direito é clara. Uma teoria sobre a natureza do direito - uma que afirme, por exemplo, que o direito alega ter autoridade legítima e, assim, pode ser identificado sem que se recorra a juízos morais ou avaliativos - não tem nada a dizer sobre seu conteúdo em determinado sistema

\footnotetext{
${ }^{97}$ Trata-se de uma citação de "Casos Difíceis" (DWORKIN, 1975 apud RAZ, 1995, p. 222): "To establish the content of the law of a certain country one first finds out what are the legal sources valid in that countcy and then one considers one master question: Assuming that all the laws ever made by these sources which are still in force, were made by one person, on one occasion, in conformity with a complete and consistente political morality (i.e. that part of a moral theory which deals with the actions of political institutions), what is that morality?"
} 
jurídico ${ }^{98}$. Essas característica da teoria raziana ficará mais clara com uma breve análise dos trabalhos nos quais o autor aborda claramente alguns problemas metodológicos da teoria do direito.

\subsubsection{O método raziano para a teoria do direito}

Em alguns trabalhos mais recentes, Raz se propôs a identificar a maneira pela qual ele julgar esta realizando sua teoria do direito, de maneira a diferenciar seu método de uma abordagem avaliativa e engajada com a de Dworkin.

Para ele, a teoria do direito, em sentido estrito, é a explicação sobre a natureza do direito, que é bem sucedida se: (i) é composta por proposições necessariamente verdadeiras sobre o direito e (ii) explica o que é o direito. (RAZ, 2004, p. 17)

O segundo critério de sucesso, que exige poder explicativo das proposições da teoria, poderia ser cumprido, segundo Raz, por uma análise que (i) coloque as condições do conhecimento envolvido no "domínio completo" do conceito, que é o conhecimento de todas as características essenciais da coisa a qual o conceito se refere; (ii) explique o entendimento envolvido nesse "domínio completo"; (iii) explique as condições para a "posse mínima" do conceito" ${ }^{99}$, (iv) explique as habilidades requeridas para essa "posse mínima" (RAZ, 2004, p. 21-22).

A primeira condição é a mais importante, e determina o que é referido pelo conceito. Como se nota, Raz propõe um método de análise conceitual que liga o poder explicativo da teoria à possibilidade de se chegar a "características essenciais" daquilo que é referido pelo conceito. Segundo esse método, explicar um conceito é uma atividade próxima à tarefa de explicar a natureza do que é conceituado, mas as duas atividades não se confundem. A explicação do conceito envolve mais do que a exposição das características essenciais (ver condições (ii) a (iv) acima), e é, segundo Raz, uma tarefa secundária da teoria do direito (Ibid., p. 24).

\footnotetext{
${ }^{98}$ Ao concluir esse artigo no qual elabora sua tese sobre a natureza do direito, Raz afirma: "First, none of the above bears on what judges should do, how they should decide cases. The issue addressed is that of the nature and limits of law. If the argument here advanced is sound, it follows that the function of courts to apply and enforce the law coexists with others. One is authoritatively to settle disputes, whether or not their solution is determined by law. Another additional function the courts have is to supervise the working of the law and revise it interstitially when the need arises." (RAZ, 1995, p. 233)

99 A "posse mínima" do conceito envolve conhecer propriedades essenciais ou não essenciais da coisa referida pelo conceito, propriedades cujo conhecimento é necessário para que a pessoa tenha o conceito, ainda que não sejam suficientes para afirmar que ela o domina completamente.
} 
Não seria um erro pressupor que o direito tem uma natureza essencial que, como tal, não se altera? Afinal, é parte do entendimento que compartilhamos sobre o direito a noção de que seu conceito muda ao longo do tempo, sendo sensível a alterações nas práticas políticas e sociais. Sobre isso, Raz faz dois esclarecimentos (Ibid., p. 27-30). Em primeiro lugar, não precisamos acreditar que algo tenha propriedades essenciais para que estas propriedades, de fato, existam - que a água tenha a estrutura $\mathrm{H} 2 \mathrm{O}$ independe de que alguém acredite nisso.

Em segundo lugar, a investigação que a teoria do direito se propõe a fazer é voltada à natureza de uma determinada instituição, e não exatamente ao significado de termos. Assim, quando se fala em propriedades essenciais do direito não se trata de uma caracterização do conceito de direito ou da maneira como ele é usado, sim, da instituição social que é designada pelo conceito. O fato de que o conceito muda, mas ainda assim permanece sendo usado para designar determinada instituição, ao invés de representar uma objeção à ideia de que o direito possui propriedades essenciais pode ser visto, assim, como uma confirmação de tal ideia. Tais propriedades essenciais não são invocadas para dar conta do significado de um termo (direito), mas para elaborar uma "tipologia das instituições sociais".

Segundo Raz, "Nós construímos uma tipologia de instituições fazendo referência a propriedades que consideramos, ou iremos considerar, como essenciais ao tipo de instituição em questão" (RAZ, 2004, p. 29). ${ }^{100}$ É importante notar que direito não é um termo cujo uso é direcionado à identificação de um único aspecto central de uma instituição social em particular. Trata-se de um termo plurívoco. Apenas em casos nos quais o termo tivesse acepção única, voltada à identificação de um aspecto central da instituição, a tarefa de explicar a natureza desta e a tarefa de explicar o significado do termo estariam associadas.

Esse segundo ponto é fundamental para compreender a abordagem metodológica de Raz. Para esse autor, a teoria do direito, tendo como objetivo explicar a natureza de uma instituição, faz parte das ciências sociais. Mas essa ideia não deve nos levar a supor que, como em outras áreas das ciências sociais, a teoria do direito possa estipular conceitos que sejam mais úteis à teoria ou com vistas a atingir virtudes teóricas, tais como elegância ou simplicidade. Isso porque, ao estudar a natureza do direito, não estudamos um conceito elaborado por acadêmicos para explicar a sociedade, mas uma noção usada por todos,

${ }^{100}$ Tradução livre de "We build a tipology of institutions by reference to properties we regard, or come to regard, as essential to the type of institution in question". 
como parte do entendimento da sociedade em que vivem e de outras sociedades. Em certo sentido, portanto, estudar a natureza do direito é estudar nossa própria autocompreensão enquanto sociedade. ${ }^{101}$

Em um argumento claramente dirigido à metodologia dworkiniana, Raz afirma que a ideia de que existe desacordo teórico nos tribunais não significa que a filosofia do direito e o próprio direito sejam parte de uma mesma prática. A noção do que é direito não existe em todos os momentos nos quais alguém é desafiado a defender suas ações com argumentos teóricos (RAZ, 2004, p. 34). Além disso, as cortes não tem autoridade especial para definir noções que "têm uma vida" fora do direito (por exemplo, que o conceito "promessa" seja relevante para a decisão de um determinado caso, não significa que a concepção adotada pelo tribunal na resolução desse caso seja uma concepção que deverá se disseminar na sociedade). (Ibid., p. 35) A teoria do direito, assim, não é parte da prática jurídica, de maneira que ela não é, como esta, um empreendimento localizado e paroquial. (Ibid., p. 36)

Raz afirma, por fim, que não é necessário que uma sociedade tenha o conceito de direito para que se diga que existe direito nessa sociedade, o que seria uma divergência de sua teoria em relação à de Dworkin, para quem o direito é uma prática interpretativa que apenas existe em sociedades nas quais há consciência da natureza da prática e do seu caráter interpretativo (Ibid., 38-39).

O que a discussão metodológica feita por Raz parece mostrar é que sua visão da teoria do direito abarca, de maneira clara, pelo menos uma visão "substantiva": a visão de que o direito é uma instituição social com um caráter único e distinto ao longo do tempo, e que possui relevância não só para a prática jurídica, mas para toda a sociedade. A seguinte passagem deixa isso claro:

Algumas pessoas estão inclinadas a concluir que na teoria do direito não deve estar incluída uma teoria sobre a natureza do direito, uma vez que isso levaria a uma discrepância entre o que tal teoria diria e as visões assumidas pelos diversos sistemas jurídicos. Esta conclusão parece-me equivocada, por compreender mal as relações existentes entre teoria sobre a natureza do direito e o próprio direito. Ela ignora o fato de que o direito é importante não apenas para juristas, e aqui não me refiro apenas à importância de fixar as responsabilidades jurídicas de cada pessoa. O direito é uma importante instituição social, e existe

101 "In large measure what we study when we study the nature of law is the nature oof our own selfunderstanding. The identification of a certain social institution as law is not introducted by sociologists, political scientists, or some other academics as part of their study of society. It is parto $\mathrm{f}$ the selfconsciousness of our society to see certain institutions as legal. And that consciousness is part of what we study when we inquire into the nature of law" (RAZ, 2004, p. 31) 
um interesse em entender sua natureza enquanto uma instituição social específica. $\mathrm{O}$ fato de o direito ser uma instituição dotada de certas características não muda diante do diagnóstico de que neste ou naquele país ele adquiriu determinada extensão, ou mesmo deixara de estar presente em determinados âmbitos. A teoria do direito do direito está presente em dois estágios, ou, alternativamente, tem uma ambição limitada. O primeiro e mais importante estágio define de que tipo de instituição social é o direito, e o segundo estágio explica porque o direito neste ou naquele país ultrapassou determinadas fronteiras ou abriu mão de estar presente em todo seu território. Estas variações não precisam ir contra a afirmação de que a característica distintitva do direito enquanto instituição é tal qual a teoria descreve. Assim, a teoria pressupõe determinadas fronteiras e convive com variações em casos específicos. Nós estamos familiarizados com este tipo de estrutura em todos os constructos humanos (RAZ, 2004, p.11-12) ${ }^{102}$

Assim, o compromisso metodológico de Raz parece direcionado à realização de uma teoria diversa da proposta por Dworkin. Ela parece ter um caráter mais "sociológico", e não se preocupa em apontar o que é o direito no caso concreto ${ }^{103}$. Apesar disso, não é dessa maneira que os autores se colocam no debate: a teoria raziana e a teoria dworkinana são vistas como opositoras, e o debate entre elas é central para a questão do caráter da teoria do direito.

\subsection{A teoria do direito "indiretamente avaliativa"}

A partir das considerações de Raz, Julie Dickson pretendeu defender, de maneira sistemática, um determinado tipo de metodologia que denominou teoria do direito “indiretamente avaliativa" (Dickson, 2001). Trata-se de um método que, ainda que reconheça a necessidade de avaliação na teoria, e da possibilidade de o direito estar ligado à moral na prática, afirma ser possível não tomar partido sobre as alegações de

\footnotetext{
${ }^{102}$ Tradução livre de "Some are inclined to conclude that legal theory should not include a doctrine about the nature of law, for that will lead to a discrepancy between it and the view taken by various legal systems. That seems to me a mistaken conclusion, misconceiving the relations between the theory of the nature of law and the law. It ignores the fact that the law is important to people other than the lawyers, and I do not mean important in establishing their legal liabilities. It is an important social institution and there is an intererest in undestanding its nature as a disctintive social institution. That it is an institution of a certain character is not contradicted by the fact that in this ou that country it has accrued certain extensions, or has shied away from some areas. If you like, the theory of law proceeeds in two stages, or alternatively has a limited ambition. The first and most important stage establishes the kind of social institution the law is, the second explains why the law in this or that country has extended itself beyond some boundaries or shied away from possessing its full territory. These deviations need not negate the claim that its character as a distinctive institution is as the theory describes. So the theory implies boundaries, and allows for deviations from those boundaries in individual cases. We are familiar with this structure in all human products."

${ }^{103}$ Uma das colocações mais repercutidas de Hart no Posfácio a $O$ Conceito de Direito é a de que ele e Dworkin estariam fazendo dois tipos de teoria distintos, que não necessariamente precisariam se opor.
} 
normatividade da prática jurídica. $\mathrm{O}$ argumento central é de que algumas questões referentes à importância moral do direito e à pergunta de se nós devemos obedecê-lo são apoiadas por características do próprio direito, mas seria possível saber que tais características são relevantes para responder questões moralmente avaliativas sem pretender oferecer respostas substantivas às questões (DICKSON, 2004, p. 139).

Assim, como sintetiza John Gardner no Prefácio à obra de Dickson (2001, p. vii), o argumento da teoria indiretamente avaliativa não pretende negar que, em certo sentido, todos os teóricos são e sempre foram interpretativistas em relação à natureza do direito ${ }^{104}$, mas a questão real é se todos os intérpretes devem ser intérpretes construtivos $^{105}$, isto é, se eles seriam forçados a explicar o direito de uma maneira "favorável", fazendo com que o "importante" esteja alinhado com o "bom".

Segundo Dickson, a "teoria do direito analítica" deve ser avaliada por "critérios de sucesso", e não exatamente pelo objeto que aborda. O que esse tipo de teoria não são as propriedades essenciais que identifica no direito, mas o fato de que afirma que o direito tem tais propriedades, e que a teoria pode identificá-las e explicá-las. (DICKSON, 2001, p. 21).

A verdade é uma condição necessária, mas não suficiente, da teoria do direito analítica, pois ela deve se preocupar com "aquilo que é mais importante e característico do fenômeno que se investiga”, sendo sensível “à maneira pela qual aqueles que vivem sob o direito o veem" (Ibid., p. 25)

Assim, nenhuma teoria do direito deixa de ser avaliativa. Há um sentido banal no qual avaliações devem ser feitas: qualquer teoria deve possui algumas "virtudes", como "simplicidade, clareza, elegância, abrangência e coerência". São "valores puramente metateóricos". (Ibid., p. 32)

A teoria do direito, no entanto, envolve mais que avaliações banais sobre as "virtudes" da teoria. Isso porque os dados a serem explicados pela teoria têm uma natureza especial (Dickson, 2001, p. 40 e ss.). Isso porque, o conceito de direito, ao contrário de

104 "They all aimed to explain law and legally related phenomena in a way that played up the important and played down the unimportant" (GARDNER, in DICKSON, 2001, p. vii, grifos acrescentados).

${ }^{105} \mathrm{O}$ termo interpretação construtiva é mais usado em O Império do Direito (DWORKIN, 1986), e não é retomado com frequência em Justice for Hedgehogs (DWORKIN, 2011). Acredito que o abandono do termo seja decorrente da visão de que - como já estava sugerido em O Império do Direito (DWORKIN, 1986, p. 53) - a descrição da interpretação construtiva é a descrição de qualquer tipo de empreendimento interpretativo, o que significa dizer que toda interpretação é construtiva: ela busca colocar o objeto interpretado em sua melhor luz. Essa parece ser a abordagem de Justice for Hedgehogs, que será discutida adiante. 
conceitos de ciências naturais, ou mesmo de alguns conceitos usados na sociologia ${ }^{106}$, faz parte do modo como as pessoas veem o mundo - elas usam o conceito de direito para atribuir sentido a suas práticas, o conceito faz parte de sua autocompreensão.

Alguns teóricos defendem que o direito é capaz de atribuir sentido às compreensões e avaliações de membros de uma sociedade em razão da conexão que ele tem com a moralidade, que faz com seja da sua natureza se apresentar por meio de conceitos morais como autoridade, dever, obrigação e direito. Mesmo positivistas como Raz consideram importante explicar de que forma o direito tem um "peso normativo" sobre a vida das pessoas, exercendo autoridade sobre elas.

Qual seria então o sentido em que a teoria poderia se comprometer com avaliações que não sejam "banais", puramente metateóricas? Para responder a pergunta, Dickson estabelece uma diferença crucial em seu trabalho, entre proposições diretamente avaliativas e indiretamente avaliativas. Proposições diretamente avaliativas estabelecem o valor de algo como bom ou mau - e.g., "X é bom”. Proposições indiretamente avaliativas, por outro lado, não se direcionam à "substância" ou ao "conteúdo" do objeto, ainda que o avaliem, de alguma forma - por exemplo, "X é importante". É claro que de uma proposição diretamente avaliativa, posso derivar uma proposição indiretamente avaliativa, mas isso não significa que o contrário seja verdade (DICKSON, 2001, p. 53-54).

Um exemplo pode ajudar a esclarecer o argumento da autora. Posso dizer, por exemplo, que, para adequadamente entender "Memórias Póstumas de Brás Cubas", devo considerar que seu autor pretendeu fazer uma crítica à sociedade brasileira do século XIX. Ao considerar essa circunstância importante para o entendimento da obra, isso não significa que estou atribuindo à crítica em si algum valor positivo ou negativo, ou mesmo que eu esteja considerando que o autor foi bem-sucedido em realizá-la, mas simplesmente que ela deve ser levada em conta se quero entender adequadamente o livro.

Da mesma forma, que o direito alegue ter autoridade moral pode ser considerada pelo teórico uma importante característica do próprio direito, a qual deve ser explicada, mas isso não significa que o teórico deva considerar essa alegação justificada ou injustificada. Além disso, essa característica pode ser considerada importante mesmo que a alegação não seja justificada, ou nunca possa ser justificada (Ibid., p. 55).

\footnotetext{
106 Segundo Dickson, é característico de alguns conceitos sociológicos que eles não façam parte da autocompreensão da comunidade a que ele se refere.
} 
Nesse ponto, poderia se objetar que proposições indiretamente avaliativas somente se sustentam por proposições diretamente avaliativas ${ }^{107}$. Dickson concede que, ainda que este possa ser o caso, não é verdade que sempre seja assim (DICKSON, 2001, p. $58)$.

Há diferentes modos pelos quais as proposições indiretamente avaliativas segundo as quais "X é importante" podem se sustentar sem recorrer às diretamente avaliativas segundo as quais "X é bom (ou ruim)", tais como: (i) X é uma característica que o direito invariavelmente exibe, revelando o seu distinto modo de operação; (ii) aqueles que estão submetidos ao direito possuem certas crenças relacionadas a $X$, o que indica que $X$ é central para seu autoentendimento (enquanto sujeitos de direito); (iii) X tem relevância para questões práticas; $\mathrm{X}$ é relevante para várias questões diretamente avaliativas sobre se o próprio $X$ é bom, e se a instituição que exibe X é boa. (Ibid., p. 64)

Em posse dessas distinções, Dickson pretende criticar o método da interpretação construtiva. Esse método, segundo a autora, desenvolve-se em três passos principais: (i) supõe que teóricos e participantes da prática estão engajados na mesma empreitada interpretativa, e que a teoria do direito e a teoria da decisão jurídica (adjudicação) são a mesma teoria, (ii) a atividade na qual estão todos engajados é a interpretação dos materiais jurídicos de acordo com certo esquema interpretativo, de maneira a gerar certos resultados, (iii) a interpretação busca mostrar os materiais jurídicos em sua melhor "luz moral".

O segundo passo, que ela elabora de forma um tanto obscura, será o foco de sua crítica. Tal crítica é direcionada à maneira pela qual Dworkin caracterizou a "forma ou gênero" ao qual o direito pertence. Essa ideia de "forma ou gênero" é muito importante para a defesa da interpretação construtiva, pois a proposta desta é justamente que o intérprete atribua à prática um propósito que a torna o melhor exemplo da forma ou gênero ao qual ela pertence (DWORKIN, 1986, p. 52).

Dickson, no entanto, confunde essa noção de forma/gênero com a ideia de propósito, ou point. Ela assume que a alegação de que o direito justifica a coerção estatal é o que demarca a forma/gênero ao qual, segundo Dworkin, o direito pertence. (DICKSON, 2001, p. 105)

\footnotetext{
${ }^{107}$ A autora elabora essa objeção como uma possível crítica que poderia ser feita por John Finnis, que é o mais relevante teórico do direito natural contemporâneo, e ofereceu importantes contribuições ao debate metodológico, especialmente no capítulo 1 de seu Natural Law and Natural Rights (FINNIS, 1980). O argumento de Finnis sustenta, em síntese, que, para apreciar o "caso focal" do direito (suas características mais relevantes), o teórico precisa ter uma posição sobre quais são os verdadeiros requisitos da razão prática , e de que maneira o direito influencia em tais requisitos.
} 
Tal alegação é feita por Dworkin para apresentar um possível point para o direito, e, assim, elaborar, de maneira provisória, suficientemente incontroversa e abstrata, um conceito de direito a partir do qual o debate sobre diferentes concepções poderá se organizar.

\begin{abstract}
Assim como nós entendemos melhor a prática da cortesiaem determinado estágio da sua história encontrando um acordo geral sobre a proposição abstrata de que a cortesia é uma questão de respeito, nós podemos entender o direito melhor se pudermos achar uma descrição abstrata de seu propósito, a qual possa ser aceita pela maior parte dos teóricos do direito de maneira que seus argumentos possam se desenvolver na base que ela fornece.

Nem a teoria do direito nem meus próprios argumentos nas partes posteriores desse livro dependem de encontrar uma descrição abstrata como essa. Como eu disse, a filosofia política avança a despeito das nossas dificuldades em encontrar uma formulação adequada do conceito de justiça. Ainda assim, eu sugiro o seguinte argumento como uma abordagem abstrata que organiza argumentos adicionais sobre as características do direito. [...] $\mathrm{O}$ direito insiste que a força não seja usada ou mantida, não importando o qual útil isso possa ser para os fins em vista, ou o quão benéficos ou nobres sejam esses fins, exceto da maneira permitida ou requerida pelos direitos e responsabilidades individuais que fluem das decisões políticas passadas a respeito da justificação da força coletiva.

Nessa abordagem, o direito de uma comunidade é o esquema de direitos e responsabilidades que atendem a este complexo parâmetro: eles permitem coerção porque eles derivam do tipo correto de decisões políticas passadas. Eles são assim direitos e responsabilidades jurídicos. ${ }^{108}$ (DWORKIN, 1986, p. 92-93)
\end{abstract}

Como se percebe pela passagem, Dworkin deixa claro que essa descrição da prática - que é, na verdade, uma tentativa de caracterizar o conceito de direito de forma abstrata, "acima" das diferentes concepções - não é uma constrição à atividade teórica: esta não depende da formulação de uma abordagem abstrata deste tipo.

\footnotetext{
108 Tradução livre de "Just as we understood the practice of courtesy better at one stage in its career by finding general agreement about the abstract proposition that courtesy is a matter of respect, we might understand law better if we could find a similar abstract description of the point of law most legal theorists accept so that their arguments take place on the plateau it furnishes.

Neither jurisprudence nor my own arguments later in this book depend on finding an abstract description of that sort. Political philosophy thrives, as I said, in spite of our difficulties in finding any adequate statement of the concept of justice. Nevertheless I suggest the following as an abstract account that organizes further argument about law's character. [...] Law insists that force not be used or withheld, no matter how useful that would be to ends in view, no matter how beneficial or noble these ends, except as licensed or required by individual rights and responsibilities flowing from past political decisions about when collective force is

justified. The law of a community on this account is the scheme of rights and responsibilities that meet that complex standard: they license coercion because they flow from past decisions of the right sort. They are therefore 'legal' rights and responsibilities."
} 
Dickson, no entanto, acredita que essa descrição abstrata tem fortes ramificações no tipo de metodologia que uma teoria deve adotar. A posição metodológica que surge dessa abordagem defende que a teoria seja constituída de proposições diretamente avaliativas sobre as características do direito, pois, para identificá-lo e entendê-lo, será necessário considerá-lo um fenômeno moralmente justificado, que legitima o uso a força coletiva (DICKSON, 2001, p. 106).

Assim, segundo a autora, é a "função" atribuída por Dworkin ao direito que determina sua posição metodológica. Essa posição de Dickson nos faz supor que, para ela, toda a discussão de Dworkin sobre práticas interpretativas - que é muito anterior à apresentação do direito como um fenômeno ligado à coerção estatal - não o comprometeria com a teoria "diretamente avaliativa". Apenas ao afirmar substantivamente uma função para o direito é que tal comprometimento surgiria.

Caso Dickson realmente entenda dessa forma, ela estaria afirmando a possibilidade de que uma prática interpretativa possa ser objeto de uma teoria indiretamente avaliativa. Seria realmente esse o propósito da autora? Algumas evidências parecem sugerir que sim, pois ela não critica a caracterização da prática como um exercício de interpretação construtiva, mas apenas a caracterização da teoria como um exercício desse tipo.

Ela avança em sua crítica ao afirmar que a visão de Dworkin sobre a função do direito está longe de ser suficientemente abstrata e provisória, e defnine limites e possibilidades muito claros para qualquer teoria do direito, de maneira a deixar de lado muitas questões importantes antes mesmo que elas sejam colocadas ${ }^{109}$. (Ibid., 108)

Em relação à abstração, Dickson afirma que a formulação de Dworkin sobre a função do direito pode ser abstrata apenas se considerarmos a atividade do juiz interpretando um caso particular, mas não se considerarmos as diversas interpretações oferecidas pelos teóricos do direito. Isso porque as proposições oferecidas pelos teóricos competem em um nível mais geral, no qual eles discordam justamente sobre qual é a função ou gênero do direito. Assim, eles não estão interpretando construtivamente da maneira como colocada por Dworkin.

Quando falamos no nível da teoria, surge o problema de saber se o que está disponível para interpretação (função/gênero/point) é também o que deve estar oferecendo um limite para o próprio processo interpretativo. Diante disso, Dworkin teria duas

\footnotetext{
${ }^{109}$ Poderíamos acrescentar: antes que elas sejam colocadas na teoria, não na prática.
} 
alternativas: (i) dizer que a própria ideia de função do direito também está disponível para interpretação do teórico ou (ii) fixar essa função de maneira que o processo de interpretação construtiva tenha limites. Segundo Dickson, a primeira alternativa traria o ônus de mostrar quais são, então, os limites da atividade da interpretação construtiva. Dworkin não teria se preocupado muito com essa questão em "O Império do Direito" porque sua teoria se desenvolve a partir, e é direcionada por, sua visão sobre a decisão judicial, e não o contrário. Então, ele estaria preocupado em fixar os limites da atividade do juiz no caso concreto, mas não do teórico (DICKSON, 2001, p. 110).

Ao formular a ideia de função do direito, Dworkin já estaria fixando o caráter do direito em relação a questões abstratas da própria teoria do direito. Muitas das questões que essa teoria pretende responder - se o direito tem realmente uma função, se ela faz dele um empreendimento moralmente bom ou justificado - restariam então respondidas pela postulação dworkiniana.

Isso se acentua ao percebermos que, quando confrontado por teorias do direito que discordam da sua visão sobre qual é a função do direito ${ }^{110}$, ou mesmo que o direito tenha alguma função, Dworkin apenas as reinterpreta de acordo com sua própria abordagem teórica. Segundo Dickson, Dworkin exige que qualquer teoria do direito tenha uma posição sobre qual é a função do direito, e uma posição que é na verdade muito semelhante à dele próprio: qualquer teoria deve explicar como se dá o funcionamento do direito de maneira a justificar a coerção estatal. (Ibid., p. 112-114)

Dworkin argumenta que é na "tese social" "111, segundo a qual o direito pode ser identificado por meio de testes que recorrem a fatos sociais, que o argumento sobre a função do direito pode ser encontrado no positivismo.

Dickson parece conceder que ele estaria, em parte, correto, pois a tese das fontes, para Raz, é fundamentada por um argumento segundo o qual uma importante função do direito é emitir diretivas autoritativas ${ }^{112}$, o que só se torna possível caso haja uma maneira de identificar tais regras que seja pública e não recorra a argumentos morais. ${ }^{113}$

\footnotetext{
110 Tais como as teorias positivistas, que divergem de Dworkin ao assumir o que pode se chamar de “"abordagem institucional', segundo a qual o direito é caracterizado não por sua função abrangente, mas sim por seu método: pela maneira, ou pelo conjunto de formas, pelas quais realiza as coisas que realiza na sociedade". (DICKSON, 2001, p. 112)

${ }^{111}$ A tese das fontes, para usar a terminologia raziana.

112 Ver tópico acima.

113 "According to Raz, it is part of how we understand the kind of thing which law purports to be, and the kind of functions which it is attempting to perform, that we understand it as issuing directives which claim to be authoritative in this manner. The sources thesis gains support from this argument concerning one of the functions of law, because, Raz claims, it will only be possible for law to issue purportedly authoritative
} 
Mas a autora afirma que, de qualquer maneira, persistem duas diferenças entre as abordagens dworkiniana e raziana. Em primeiro lugar, Raz não se compromete com nenhuma tese segundo a qual o direito pode ser caracterizado por uma função abrangente, seja ela qual for. A função de proporcionar certeza sobre quais condutas são vinculantes e têm força de autoridade é uma entre muitas que o direito pode ter.

Em segundo lugar, Raz nega que, para fundamentar a tese das fontes por meio do argumento referente a uma das funções do direito, seja preciso avaliar moralmente o direito, ou elaborar um argumento moral a favor de uma determinada função que o direito possa ter. Para fazer essa fundamentação, Raz precisa somente afirmar que a tese das fontes

reflete e explica um importante aspecto da maneira pela qual nós entendemos o funcionamento da instituição social do direito. $\mathrm{O}$ argumento de Raz é que a existência de instituições sociais que se propõem a emitir diretivas autoritativas [...] é uma importante característica da vida social. Estejam essas instituições jurídicas justificadas ou não em fazê-lo, essa é a maneira pela qual elas invariavelmente operam, e isso é uma importante característica do direito a ser explicada (DICKSON, 2001, p. 120). ${ }^{114}$

A característica a ser explicada é, em outras palavras, a alegação do direito de que ele exerce autoridade sobre nós, com a emissão de diretivas que influenciam nossa razão prática e recaem sobre ela. Que esta seja uma importante característica da vida social, não significa aceitar que o direito realmente tenha esse tipo de autoridade, ou que seja bom ou mau que ele a tenha. (Ibid., 121)

A teoria do direito "indiretamente avaliativa" defendida por Dickson possui uma forte conexão com abordagens institucionais do fenômeno jurídico, tendo como foco a explicação da "existência, estrutura e modo de operação de certas características importantes do direito" (Ibid., p. 126). A abordagem dworkiniana, por outro lado, quer

rulings which claim to be binding upon those to whom they are addressed simply in virtue of the fact that they issue from the authority in question, if there is a way of identifying those rulings which is publicly ascertainable, and which does not require resort to moral argument" (DICKSON, 2001, p. 117).

114 Tradução livre de "[For Raz, then, to support the sources thesis with an argument about one of law's functions - namely the function of providing publicly ascertainable standards of conduct which purport to express a binding and authoritative judgement regarding how society is to be organised-is merely to claim that] the sources thesis reflects and explains one important aspect of the way in which we understand the social institution of law to function. Raz's claim is that the existence of social institutions which purport

to issue authoritative directives [in the manner and for the reasons described above] is an important feature of social life. [...] Whether or not those legal institutions are justified in so doing, that is the manner in which they invariably operate, and this is an importante feature of the law to be explained." 
identificar e explicar o direito por meio de avaliações e justificações morais de algumas dessas características.

A autora deixa claro que seriam necessários mais argumentos para mostrar a correção da opção metodológica pela teoria do direito indiretamente avaliativa, mas afirma que uma metodologia como a dworkiniana possuiria a desvantagem evidente de "fechar" questões - como se o direito é um fenômeno moral, ou se ele é moralmente justificado logo de início. A teoria indiretamente avaliativa, por outro lado, permite que o teórico inicie suas observações de maneira mais "livre", no sentido de que não determina de início as respostas àquelas questões.

Dickson conclui afirmando que existem, na teoria do direito, duas empreitadas muito diversas: de um lado, uma que procura responder questões como "o que é direito/qual é a característica específica desse tipo de instituição social”, de outro, uma teoria voltada a responder "quais normas devem ser obedecidas" ou "sob quais condições os sistemas jurídicos estão justificados" (DICKSON, 2001, p. 134).

Ainda que trate essas duas empreitadas como essencialmente diversas, a autora concede a existência de relações entre elas. Proposições indiretamente avaliativas podem ser fundamentadas por proposições diretamente avaliativas: posso dizer que determinada característica é importante porque ela é relevante para responder às questões sobre se o direito é um fenômeno bom ou moralmente justificável. Subjacente a esse raciocínio, está a ideia de que, para avaliar algo, preciso antes conhecer bem esse algo: como saber se devo obedecer o direito sem saber exatamente o que é o direito? Mais ainda, é importante saber o que é o direito antes de tentar estabelecer os parâmetros pelos quais ele deve ser julgado. (Ibid., p. 136)

Para Dickson, ainda que não seja possível separar completamente as questões metodológicas das questões "substantivas" - o que faz com que se argumento em favor da teoria indiretamente avaliativa seja necessariamente limitado, pois não há maneiras de defender determinada abordagem metodológica sem recorrer a argumentos sobre a própria natureza do objeto -, algumas reflexões sobre o tipo de instituição social que é o direito nos fariam perceber as vantagens da opção metodológica defendida pela autora.

Em especial, o caráter institucional do direito assume grande relevância: o direito opera por "instituições e procedimentos diferenciados, e faz isso independentemente destas instituições resultarem em algo que representa coerção moral justificada ou em algo 
promulgado em favor do bem comum" (Ibid., p. 141). Não só o direito opera dessa forma, como nós o encaramos assim ${ }^{115}$.

São justamente essas características, as quais diferenciam o direito frente a outras instituições sociais, que recebem a atenção da teoria do direito indiretamente avaliativa, como algo importante e significativo a ser explicado. É da própria natureza do dado com o qual lida a teoria jurídica que surge a possibilidade de, sem recorrer a proposições diretamente avaliativas, identificar o fenômeno jurídico e suas características mais importantes de serem explicadas. Mais ainda, é apenas depois de realizar essa explicação que passa a ser possível avaliar se as instituições e procedimentos jurídicos são capazes de justificar moralmente a coerção estatal ou criar razões para ação para aqueles que estão submetidos ao direito ${ }^{116}$.

Assim, retomando o questionamento anteriormente feito, parece ser agora evidente Dickson não está comprometida em negar que a prática jurídica é uma prática interpretativa, da maneira como descrita por Dworkin. Sua visão da teoria jurídica, no entanto, afirma que esta não precisa participar de tal prática (e talvez nem seja bom que ela participe), enxergando seu propósito, ou sua intencionalidade, da maneira como os participantes a enxergam.

Acredito que, para refutar o argumento de Dickson, não é suficiente afirmar que ela não compreende o elemento intencional (point), confundindo-o com uma mera função. (MACEDO JR., 2012, p. 103-106) É certo que a intencionalidade, ou o significado, das práticas não é equivalente a sua função. Esta, ao contrário daquela, pode ser analisada externamente. $\mathrm{O}$ argumento de Dickson, no entanto, nega a necessidade e a adequação de a teoria tomar a ideia de intencionalidade para explicar o fenômeno jurídico, especialmente enquanto uma instituição social.

\footnotetext{
115 "That we regard there as being something important and distinctive about forms of social organisation which we hold to be legal systems, and that we regard those forms of social organisation as always operating via distinctive institutional routes and procedures, irrespective of the moral or immoral substance of what they are up to on particular occasions is simply part of the data which legal theory has a duty to illuminate and help us better understand." (DICKSON, 2001, p. 142)

116 "It is these distinctive features of legal regulation and of the way in which we think about law which indirectly evaluative legal theory picks out as important and significant to explain. Owing to the nature of the data with which legal theory is concerned, it is possible to identify legal phenomena, and to pick out which features of the legal system are the most important to explain, without delving into directly evaluative questions regarding when and under what conditions such a system is morally justified. Once we have dealt with and explained the nature of those distinctive institutions and procedures which we account as legal, we will then be in a position to go on to consider whether those institutions and procedures are, for example, capable of morally justifying state coercion, or create reasons for action for those subject to the law which they would not otherwise have." (Ibid., p. 142)
} 
A autora afirma que Dworkin, ao estabelecer sua visão da função (ou intencionalidade, como queira) do direito, não apenas colocou os teóricos "no mesmo barco", mas definiu "a estratégia, composição e instância de um time da teoria do direito do qual todos teriam que ser membros caso queiram ter a chance de construir uma teoria jurídica plausível". Os teóricos de tal "time" devem acreditar em três pontos cruciais: (i) que é necessário avaliar moralmente o direito para entendê-lo, (ii) que qualquer teoria jurídica adequada irá explicar como a função geral do direito é policiar e justificar a coerção estatal e (iii) que uma teoria do direito bem sucedida irá mostrar o direito em sua melhor luz moral, como aquilo que justifica o uso da coerção. O argumento de Dickson visa provar que teóricos que adotam uma teoria do direito "indiretamente avaliativa" não são parte desse time: eles não aceitam que prover uma justificação geral da coerção estatal seja o principal objetivo da teoria do direito, nem que isso seja necessário para entender adequadamente o fenômeno jurídico. ${ }^{117}$

\section{Discussão}

O objetivo desse capítulo foi apresentar uma primeira formulação do interpretativismo na teoria de Dworkin, bem como as discussões que surgiram em torno desse método. Pretendi deixar claro o caráter profundamente crítico das teses lançadas por Dworkin em "Modelo de Regras II" e posteriormente desenvolvidas em O Império do Direito. Elas propõem uma abordagem da prática jurídica que radicaliza a noção de ponto de vista interno, tal como já havia sido delineada por Hart, afirmando que essas práticas devem ser entendidas como práticas de contestação e controvérsia, para as quais não existem regras compartilhadas a serem desveladas pelo teórico.

Assim, o interpretativismo, mais que uma nova descrição das práticas jurídicas, é também uma nova maneira de ver a teoria do direito, que se vê deslocada de seu papel de

\footnotetext{
117 "Dworkin's view of law's function does not merely get all legal theorists into the same ballpark, but rather defines the composition, strategy and stance of one particular jurisprudential team which Dworkin, erroneously in my view, claims that everyone must be a member of if they are to have a chance of constructing a plausible legal theory. The team in question consists of those theorists who believe that: (i) it is necessary to morally evaluate the law in order to understand it; (2) that any adequate theory of law will explain how law's overall function is to police and justify state coercion; and (3) that a successful theory of law will show law in its best moral light as that which justifies the use of such coercion. The discussion in this section is intended to show that those legal theorists who, like Raz, adopt an indirectly evaluative approach to legal theory, are not members of this team. They do not accept that providing a general justification for state coercion is the main aim of jurisprudential theorising, nor that it is necessary to attempt to provide such a justification in order to understand law adequately." (DICKSON, 2001, p. 127-8)
} 
encontrar acordos e da qual se passa a exigir uma abordagem substantiva e engajada das controvérsias surgidas na prática.

Acredito que as principais polêmicas que derivaram do interpretativismo giram em torno dessa "subversão" da teoria, que faz com que o teórico se veja na posição de justificar seu engajamento ou explicar sua neutralidade. A controvérsia em torno do argumento do "ferrão semântico" é uma reação a isso, assim como a discussão - que me parece muito mais relevante e interessante - sobre a possibilidade de realização de teorias desengajadas, que, no entanto, não descurem da normatividade da prática.

Este debate é extremamente complexo e multifacetado e aqui pretendi expor apenas algumas visões selecionadas, que acredito terem sido determinantes para a maneira como Dworkin elaborou sua teoria em obras mais recentes. Não há, neste plano, uma ruptura em relação ao que havia sendo feito, sim, um aperfeiçoamento (em Justiça de Toga) e uma abstrativização (em Justice for Hedgehogs) da teoria, ambos movimentos extremamente interessantes e instigadores para qualquer participante da prática jurídica. 


\section{INTERPRETATIVISMO NA PRÁTICA E NA TEORIA: FORMULAÇÕES MAIS RECENTES}

O objetivo deste capítulo é apresentar as formulações do interpretativismo oferecidas por Dworkin em suas obras mais recentes, analisando como tais formulações podem ser entendidas como respostas às polêmicas discutidas no capítulo anterior.

\section{Teorias e conceitos de direito}

Em Justiça de Toga (DWORKIN, 2006), Dworkin reafirma seus compromissos metodológicos e substantivos, mas criou um novo aparato teórico para aperfeiçoar os argumentos anteriores. Assim, o argumento do ferrão semântico é, neste texto, reformulado, e outro argumento que antes havia aparecido apenas de forma sutil - o de que a teoria do direito é o "prólogo silencioso" a qualquer decisão judicial - é elaborado em toda a sua força. Trata-se do argumento contra os chamados "arquimedianos", aqueles que julgam ser possível fazer a teoria em um nível "superior" ao nível no qual a prática ocorre.

Para acessar esse novo aparato teórico, é essencial entender a "conceitografia" proposta por Dworkin para analisar como nos referimos ao direito em diversos contextos e situações.

\subsection{Os conceitos de direito}

Como deve ter ficado claro até este momento, o conceito de direito que figura nas práticas jurídicas cotidianas é um conceito interpretativo, que é compartilhado pelas pessoas apenas como um "platô" abstrato no qual ocorrem as disputas entre as diversas concepções.

Podemos denominar esse conceito doutrinário ${ }^{118}$. Trata-se daquele conceito usado em proposições sobre o que o direito requer, proíbe, permite ou cria (Dworkin, 2006b, p. 2). Assim, ele é usado por todos os participantes da prática jurídica ao fazerem suas

\footnotetext{
118 A expressão em inglês é doctrinal. Acredito que ela possa ser traduzida por "doutrinária" sem maiores problemas. "Doctrine" designa normalmente um corpo teórico qualquer, mas frequentemente possui um sentido muito semelhante a "doutrina" da forma como usamos em português. O conceito doutrinário, por sua própria característica, é aquele que figura nas teorias especializadas dos diversos campos do direito ("doutrinas"): essas teorias visam mostrar o que é "requerido, proibido, permitido ou criado", exatamente no sentido que Dworkin atribui, em abstrato, ao conceito doutrinário.
} 
proposições internas: é o conceito doutrinário que advogados e juízes usam. Mas é também o conceito usado pelas proposições de teoria do direito, se entendermos esta como uma abordagem da prática interpretativa com vista a saber o que é o direito nessa prática. $\mathrm{O}$ conceito doutrinário é, como já mencionado, um conceito interpretativo: não há regras compartilhadas que guiem seu uso.

Esse primeiro tipo de conceito deve ser distinguido do conceito sociológico de direito, que usamos para identificar o fenômeno jurídico como um tipo especial de estrutura institucional social. Diferentes teóricos sociais usaram diferentes testes para identificar o direito nesse sentido sociológico. Por exemplo, a proposição de que o direito não existe onde não há instituições especializadas de enforcement coercitivo (que Dworkin atribui a Weber) faz uso de um conceito sociológico de direito (DWORKIN, 2006b, p. 3).

O conceito sociológico permite o uso de definições estipulativas, que podemos elaborar para diversos fins (como, por exemplo, organizar um projeto de pesquisa), mas não devemos supor que ele possui uma "natureza essencial". Todos nós compartilhamos um conceito sociológico rudimentar, que nos dá suficiente "margem de manobra" para estipular definições que não afrontem os usos ordinários. Trata-se de um compartilhamento criterial um tanto impreciso, que faz com que o conceito sociológico possua certa vagueza.

Sabemos, no entanto, que ele é limitado pela existência de um conceito doutrinário disponível: "nada é um sistema jurídico no sentido sociológico a menos que faça sentido perguntar que direitos e deveres o sistema reconhece". (Ibid., p. 4) ${ }^{119}$.

Dworkin identifica também um conceito de direito taxonômico, que, segundo ele, é usado apenas por uns poucos filósofos do direito para designar padrões jurídicos em oposição a padrões morais ou costumeiros. A questão aqui é meramente taxonômica porque nada de relevante decorre dela. Precisamos saber $o$ que faz as proposições de direito serem verdadeiras, não como devemos denominar essas condições de verdade; nossa escolha de chamar de padrões jurídicos os princípios morais que figuram naquelas condições, por exemplo, não tem nenhuma consequência relevante (Ibid., p. 4-5). ${ }^{120}$

\footnotetext{
119 Tradução livre de "(...) nothing is a legal system in the sociological sense unless it makes sense to ask what rights and duties the system recognizes."

${ }^{120} \mathrm{O}$ argumento sobre o conceito taxonômico é elaborado por Dworkin como uma crítica à controvérsia entre positivistas exclusivistas e inclusivistas. Enquanto os primeiros afirmam que os testes para distinguir o que é direito são baseados apenas nas fontes sociais, e não podem recorrer a argumentos morais, os segundos afirmam que há, sim, padrões morais que figuram nesses testes (SHAPIRO, 2007, p. 19-22). Para Dworkin, trata-se de uma divergência meramente taxonômica: "It is of course important what we take to be relevant to deciding what legal rights and duties people and officials have. But nothing importante turns on which part of what is relevant we describe as "the law". Why should we not say that we have considerable leeway in
} 
Por fim, compartilhamos ainda um conceito aspiracional de direito, que se refere ao ideal do direito: aquilo que por vezes denominamos legalidade ou "estado de direito" (rule of law). Trata-se de um conceito contestado, para o qual devemos decidir qual melhor concepção disponível (Ibid., p. 5).

Dworkin oferece essa conceitografia para localizar o que entende ser uma "teoria geral do direito": esta é uma abordagem geral sobre o conceito doutrinário do direito, que nos ajuda a decidir qual o melhor método de resolução dos casos concretos. (DWORKIN, 2006, p. 9).

\subsection{Reformulando o "ferrão semântico": os estágios da teoria do direito}

Segundo Dworkin, apenas como um recurso analítico, podemos enxergar a teoria do direito como um procedimento que opera em fases. Dificilmente algum teórico irá construir sua teoria separando de forma específica as diferentes fases, mas identificá-las permite identificar também diferentes tipos de teoria do direito.

Em seu primeiro estágio, que é semântico, a questão central da teoria é: “Quais suposições e práticas as pessoas devem compartilhar para que seja razoável dizer que elas compartilham um conceito doutrinário, o que lhes permite concordar e discordar, de forma inteligível, sobre sua aplicação?” (Ibid., p. 9) ${ }^{121}$

Nesse estágio, deve-se perceber que tipo de conceito - criterial, interpretativo ou de tipo natural - pode ser o conceito doutrinário de direito. Conceitos de tipo criterial são compartilhados quando as pessoas concordam numa "definição - grosseira ou precisa que coloca os critérios para a aplicação correta do termo ou frase associada" (Ibid., p. 9) ${ }^{122}$. A equilateralidade de um triângulo é um conceito preciso, mas outros conceitos criteriais são muito menos precisos. Casamento, por exemplo, é um conceito criterial moderadamente impreciso. Assim, "[d] esenvolver uma teoria desse tipo de conceito [criterial] significa propor uma definição mais precisa para algum propósito particular. Mas

making that linguistic choice so that both the 'inclusive' and the 'exclusive' diction are acceptable?" (DWORKIN, 2006b, p. 238).

${ }^{121}$ Tradução livre de "What assumptions and practices must people share to make it sensible to say that they share the doctrinal concept so that can intelligibly agree and disagree about its application?"

${ }^{122}$ Tradução livre de "[...] definition - rough or precise - that sets out the criteria for the correct application of the associated term or phrase". 
seria um erro afirmar que qualquer definição mais precisa captura a essência do conceito melhor que outras definições" (DWORKIN, 2006b, p. 9). ${ }^{123}$

O conceito interpretativo, por outro lado, diferencia-se dos outros justamente pelo tipo de suposições e práticas compartilhadas às quais se refere. Ele nos incentiva a contestar e refletir sobre o que é requerido por alguma prática que construímos. Então a prática compartilhada no uso desse conceito não é uma prática linguística convergente (como no caso dos conceitos criteriais), mas, sim, a prática de tratar o conceito como interpretativo. ${ }^{124}$ Uma teoria do conceito interpretativo será, então, uma interpretação, muito provavelmente controversa, da prática na qual o conceito figura.

O segundo estágio da teoria do direito é o “jurisprudencial”. Nesse estágio, há uma interpretação das práticas, na qual se leva em conta o valor intrínseco a elas. Neste ponto, busca-se a melhor concepção de um conceito aspiracional do direito (Dworkin, 2006b, p. 5). A pergunta no estágio jurisprudencial da teoria é: quais valores fornecem melhor concepção desse conceito?

O terceiro estágio é o doutrinário. Aqui, é construída uma abordagem sobre as condições de verdade das proposições do direito à luz dos valores identificados no estágio jurisprudencial.

Uma proposição de direito é verdadeira se fluir dos princípios de moralidade pessoal e política que fornecem a melhor interpretação de outras proposições de direito geralmente consideradas verdadeiras na prática jurídica contemporânea (Dworkin, 2006b, p. 14$)^{125}$.

No estágio doutrinário, busca-se fazer uma interpretação do conceito que leve em conta duas dimensões: a dimensão da adequação da interpretação à prática real (fit), e a

\footnotetext{
${ }^{123}$ Tradução livre de "Developing a theory of this kind of concept means proposing a more precise definition for some particular propose. But it would be a mistake to claim that any mmore precise definition better captures the essence of the concept than others."

${ }^{124}$ É importante perceber que, no conceito interpretativo, também há critérios. Os conceitos criteriais parecem, então, ser conceitos interpretativos que funcionam em práticas interpretativas menos importantes, no sentido de serem práticas desvinculadas de questões morais. O conceito de casamento é um bom exemplo. Ele é criterial se pretendo fazer uma análise antropológica de algumas sociedades ou tribos. No entanto, no momento em que se considera o casamento um direito, extensível a homossexuais, por exemplo, ele deixa de ser um conceito meramente criterial. No primeiro caso, tem-se uma interpretação explanatória, no segundo a interpretação é conceitual, e envolve raciocínio moral. Dworkin parece confirmar essa visão ao afirmar que alguns ou todos os conceitos interpretativos podem ter começado suas vidas conceituais como conceitos criteriais, mas teriam deixado de ser assim. O processo reverso é comum: um conceito criterial impreciso torna-se interpretativo "quando está incluído numa regra, direção ou princípio cuja correta interpretação gera algo importante" (DWORKIN, 2006b, p. 264, nota 7, tradução livre de "when it is embedded in a rule or direction or principle on whose correct interpretation something importante turns").

${ }^{125}$ Tradução livre de "A proposition of law is true, I suggest, if it flows from principles of personal and political morality that provide the best interpretation of the other propositions of law generally treated as true in contemporary legal practice".
} 
dimensão do valor dessa interpretação como sendo justificador da prática. As duas dimensões, adequação e valor, são aspectos diferentes de um mesmo juízo de moralidade política (DWORKIN, 2006b, p. 15).

Por fim, no estágio adjudicativo, a teoria diz o que os oficiais, dos quais se espera que realmente apliquem o direito, devem efetivamente fazer nos casos particulares. Nesse estágio, a teoria aparece plenamente como uma prática: o teórico que elabora suas concepções no estágio adjudicativo tem um discurso que opera no mesmo nível do discurso do juiz que decide um caso concreto.

A distinção entre os estágios permite ver que as respostas dadas nos estágios anteriores influenciam nos posteriores: se, no primeiro estágio, identifica-se o conceito doutrinário do direito como um conceito criterial, tem-se a percepção de que a teoria pode se limitar reportar, de maneira neutra, os critérios compartilhados no uso do conceito. Essa visão sobre a teoria é, segundo Dworkin, equivocada, pois não é possível coletar critérios usados para identificação de conceitos contestados. A natureza desses conceitos, que são disputados na prática, faz com que a teoria sobre eles seja necessariamente interpretativa.

Essa é uma maneira de formular o famoso argumento do ferrão semântico: é justamente no primeiro estágio da teoria do direito, o estágio semântico, que opera o ferrão, "picando" todos aqueles que insistem em dar um tratamento criterial para o conceito doutrinário de direito.

Novamente aqui, precisamos considerar o que já havia sido discutido anteriormente em relação a este argumento: ele não é apenas um erro de tipo "conceitual", mas uma falha de observação empírica e qualificação dos dados observados. Consiste em enxergar consenso e comportamento convergente onde este não existe. Trata-se de um julgamento equivocado acerca da moralidade política de uma comunidade.

\subsection{Confusões entre os conceitos e arquimedianos}

Segundo Dworkin, a confusão entre o conceito doutrinário e sociológico de direito, e a falha em perceber que esses conceitos são de tipos diversos pode acarretar em erros metodológicos graves. A teoria raziana é um exemplo desses erros. Raz não distingue os conceitos sociológicos e doutrinários e, como resultado, sua teoria falha para ambos.

Ela falha para o conceito sociológico porque pretende extrair "características essenciais" do direito como uma instituição social, desconsiderando que a maneira como vemos a instituição por meio de um conceito sociológico é imprecisa. Os limites deste 
conceito são maleáveis e não suportam esse tipo de análise filosófica que pretende extrair características essenciais (DWORKIN, 2006b, p. 228).

Falha também para o conceito doutrinário porque desconsidera seu caráter interpretativo, ao afirmar que toda a extensão deste conceito é dominada por uma atitude convergente dos juristas na identificação do direito por meio de fontes sociais (Ibid., p. 228-229).

Ao atribuir essas falhas à teoria de Raz, Dworkin está considerando como poderia ser essa teoria se ela pretendesse fornecer uma resposta para as questões sobre o conceito sociológico e o conceito doutrinário. Como mostra a análise feita por Julie Dickson ao apresentar a metodologia "indiretamente avaliativa", no entanto, a pretensão da teoria de Raz é puramente conceitual. Ela não está preocupada nem com os fatos empíricos nem com as exigências normativas. Coloca-se, assim, em uma perspectiva completamente externa a qualquer prática social. Em certo sentido, também Hart pretendeu realizar uma teoria puramente conceitual que se coloca fora da prática. Ele usa o método da análise conceitual ao mesmo tempo em que afirma estar realizando uma "sociologia descritiva" (HART, 1997, p.vi). Como Raz, parece querer abarcar dois tipos diferentes do conceito de direito.

Essa perspectiva é sustentável? Para responder essa pergunta, precisamos considerar para que precisamos de uma teoria. Há inúmeras práticas que adotamos em nossa vida social, mas que não julgamos demandarem uma teoria. As práticas de formar filas em bancos, ou fazer silêncio durante sessões de cinema - apenas para citar dois exemplos já mencionados na dissertação - são práticas que adotamos e para as quais não julgamos ser necessária qualquer teoria.

Porque algumas precisam? A teoria só se faz necessária quando a prática é deficiente em algum sentido, ou o entendimento sobre ela é deficiente. Pode haver vários tipos de deficiência: (i) falta de reflexão, o que gera a incapacidade de lidar com novas situações e demanda uma teoria que supra essa falha; (ii) existência de uma noção de que a prática está de certa forma limitada, sendo necessária uma teoria de maior escopo que possa situar a prática em seu contexto maior; (iii) existência de patologias localizadas na prática, o que demanda estratégias teóricas tanto de (i) quanto de (ii), de maneira a apresentar uma maneira de corrigir essas patologias; (iv) existência de práticas inteiramente patológicas. Assim, práticas interessantes podem apresentar inúmeras questões e controvérsias, e é em razão destas que a teoria surge (HALPIN, 2006, p. 69-70). 
Teorias, portanto, surgem das práticas e se voltam a estas, em um movimento que se repete sempre que surgem novas questões interessantes e controvérsias. Há alguns teóricos, no entanto, que veem sua própria metodologia de maneira que lhes parece possível falar sobre práticas sem que isso implique qualquer tipo de participação ou engajamento nestas. Podemos chamar esse teórico de arquimediano - como Arquimedes, ele pretende mover o mundo por um ponto fora deste - e vivemos a "era de ouro do arquimedianismo" (DWOKIN, 2006b, p. 141).

Arquimedianos pretendem pensar nas questões sobre direito, política, moral ou qualquer outro campo normativo de um ponto de vista que esteja localizado fora dos processos ordinários que usamos para pensar essas questões. Isso deriva de um receio de que valorizar esse "pensamento comum" seria dar preeminência para as convicções particulares das pessoas. O que o argumento do antiarquimedianismo exige, no entanto, é uma valorização das maneiras comuns de pensar e debater sobre aqueles tópicos, não um comprometimento do teórico com cada uma das convicções pessoais daqueles que participam da prática (RIPSTEIN, 2005, p. 5-6).

Ainda que a rejeição do arquimedianismo tenha origem em um argumento filosófico de rejeição ao ceticismo, a prática arquimediana é mais notável na filosofia moral: filósofos buscam uma forma de se colocar acima do campo normativo para assim resolverem as controvérsias deste campo. A mais importante resposta de Dworkin ao arquimedianismo pode ser vista nos seus trabalhos de filosofia política e filosofia do direito. Ele não apenas afirmou, de forma abstrata, que somente argumentos normativos de primeira ordem podem resolver controvérsias normativas - ele de fato ofereceu um "modelo" de como isso ocorre (Ibid., p. 6-7).

Esse "modelo" é o interpretativismo que viemos discutindo até agora. Trata-se de uma valorização do raciocínio interpretativo na teoria porque é este o raciocínio usado pelos participantes na prática.

\section{O interpretativismo em Justice for Hedgehogs}

A obra mais recente de Ronald Dworkin, Justice for Hedgehogs (DWORKIN, 2011), é certamente o seu trabalho mais abrangente e no qual sua teoria interpretativa recebeu a formulação mais acabada.

O livro visa expor de forma sistemática e integrada a epistemologia, a filosofia moral e a filosofia política elaboradas pelo autor. Sua principal tese é a unidade do valor. 
Em breve exposição, a tese afirma que todas as questões filosóficas - que é o viver bem, o que é ser bom, o que consideramos maravilhoso e o que desprezamos, como devemos tratar os outros, o que justifica o poder, e como conseguir resposta a todas essas indagações - são mutuamente dependentes. A resposta a uma influencia a resposta à outra, e devemos então lutar por respostas coerentes e que se reforcem mutuamente, pois qualquer argumento convincente sobre uma das questões deverá ser convincente também sobre as outras ${ }^{126}$.

Uma breve exposição sobre algumas passagens centrais desse livro tornará ainda mais clara a "contribuição metodológica" de Dworkin para a teoria do direito.

\subsection{Direito e moral}

Justice for Hedgehogs divide-se em quatro partes - Independência $^{127}$, Interpretação, Ética, Moralidade e Política - e apenas no último capítulo da última parte Dworkin trata do direito. Esse capítulo parece ser um pouco diferente dos demais, em que Dworkin trata de importantes conceitos morais e políticos, seja na parte sobre moralidade (“Ajuda", "Dano", “Obrigações"), seja na parte sobre política ("Igualdade", "Liberdade" e "Democracia"). Nestes capítulos, Dworkin procura construir uma abordagem desses conceitos que seja coerente com a abordagem do conceito de dignidade que está na base de sua teoria ética.

Mas o capítulo sobre o direito (DWORKIN, 2011, p. 400-415), ao contrário dos demais, não parece ser uma tomada de posição "substantiva" sobre os princípios da dignidade, sim, uma recomendação metodológica sobre como o direito deve ser visto e a

\footnotetext{
${ }^{126}$ Assim, a filosofia política e a filosofia do direito são, para Dworkin, parte da filosofia moral - elas se integram na unidade do valor. Em determinado ponto da obra, o autor menciona expressamente o que seriam os "domínios do valor" (DWORKIN, 2011, p. 90): moralidade, ética, arte e direito. Está claro porque ética e moralidade, como dois campos integrados, são domínios do valor, mas não porque Dworkin escolhe mencionar a arte e o direito como outros domínios. O livro não desenvolve posições substantivas de filosofia estética, então não é possível afirmar de que maneira esse domínio estaria integrado com os outros, mas, como o direito integra a moralidade política (Ibid., p. 405), seria perfeitamente coerente elencar a política ela mesma como um dos domínios do valor. Assim, não se pode considerar a menção expressa a esses quatro domínios como uma lista exaustiva, sendo mais razoável supor a existência de vários domínios e "subdomínios".

${ }^{127}$ Em "Independência", Dworkin pretende expor a moralidade como um campo independente dos juízos científicos, sendo assim impossível pretender aplicar os critérios de correção deste àquela. Trata-se de um desenvolvimento do chamado "princípio de Hume", segundo o qual um dever-ser não pode derivar de um ser. Se é assim, afirma Dworkin, então o campo normativo da moral deve ter uma justificação independente da abordagem científica.
} 
teoria do direito empreendida uma vez aceita a teoria segundo a qual a prática política é interpretativa e busca a integração do valor.

A escolha por adotar essa abordagem "metodológica" do direito no livro parece ser um resultado dos debates com os demais teóricos do direito, ainda não convencidos de que o interpretativismo é o método mais adequado para a teoria jurídica. Mas é preciso notar que não se trata de um capítulo de metodologia jurídica, no sentido mais próprio do termo. O objetivo principal é argumentar que devemos abandonar uma visão do direito que o enxerga como uma coleção de regras distinta da moralidade.

Essa visão do "duplo sistema", afirma Dworkin, apresenta um "erro fatal" (DWORKIN, 2011, p. 402): uma vez que aceitamos que direito e moral compõem sistemas separados de normas, não há um ponto "neutro" a partir do qual podemos decidir quais são as conexões entre os sistemas. A pergunta “Como o direito se relaciona à moral?" pode ser entendida como uma pergunta jurídica ou uma pergunta moral: qualquer resposta partirá de um dos lados e cometerá uma petição de princípio contra a posição rival.

A figura do duplo sistema apresenta, portanto, um difícil problema lógico: ela coloca uma questão que não pode ser resolvida a não ser assumindo uma resposta de início. Segundo Dworkin, essa dificuldade explica porque a teoria do direito de tradição anglosaxã se tornou "analítica" ${ }^{28}$ : ela supôs que o problema das relações entre direito e moral não era nem um problema moral nem um problema jurídico, sim conceitual. Seria possível estudar a natureza do conceito de direito sem realizar nenhuma presunção jurídica ou moral e então poderíamos ver que, por uma verdade conceitual, "o que o direito é" é diferente do que ele "deve ser”, então não há conexões conceituais necessárias entre direito e moral. (Ibid., p. 403-404)

Mas essa pretensão é minada pela ausência de uma "natureza" do conceito enquanto tal: ao contrário de conceitos criteriais, ele não tem referência em critérios compartilhados de maneira minimamente uniformes, e, ao contrário de conceitos de tipos naturais, ele também não designa uma estrutura natural a ser encontrada no mundo. Então não há nada nas nossas práticas linguísticas que possa nos ajudar a resolver os problemas das relações entre direito e moral. Ao entendermos que o conceito é na verdade um "platô" de contestação e controvérsia em uma prática política, fica claro que qualquer abordagem

\footnotetext{
${ }^{128}$ Dworkin claramente enxerga essa mudança do positivismo como uma teoria inicialmente política para uma teoria conceitual e analítica. Segundo ele, Jeremy Bentham (1748-1832) foi um "interpretativista no armário": seu positivismo era inteiramente político. (DWORKIN, 2011, p. 486, nota 6)
} 
do conceito será controversa porque refletirá uma também controversa teoria de moralidade política. (DWORKIN, 2011, p. 404)

Uma vez que escapamos da armadilha conceitual criada pela teoria analítica, podemos perceber que o direito é uma subdivisão da moralidade política, que se diferencia como uma parte distinta desta - como um ramo que se destaca de um galho maior - por ser um fenômeno institucionalizado (Ibid., p. 405). Trata-se de uma prática interpretativa que, como tal, admite apenas uma metodologia interpretativa.

\subsection{Uma abordagem abstrata da interpretação: verdade e responsabilidade moral}

Para Dworkin, a interpretação é, ao lado da ciência, um dos grandes domínios da atividade intelectual. Ela não existe em abstrato, mas apenas em gêneros: filósofos, por exemplo, interpretam conceitos contestados, enquanto sociólogos e antropólogos interpretam sociedades e culturas. Mas os diferentes gêneros têm algo em comum:

Nós achamos natural reportar nossas conclusões, em cada um e em todos os gêneros de interpretação, na linguagem da intenção ou propósito. Nós falamos do sentido ou importância de uma passagem em um poema ou peça, do propósito de um dispositivo numa lei específica, dos motivos que produziram um sonho em particular, das ambições ou entendimentos que moldaram um evento ou uma era (Ibid., p.125, grifos acrescentados). ${ }^{129}$

Como se nota, o propósito ou intenção, ideias que Dworkin pretendeu abarcar com o conceito de "point", está presente em qualquer tipo de interpretação: esta tem sempre a pretensão de reportar a intencionalidade da prática que é seu objeto.

A interpretação, portanto, visa à verdade, no sentido de que ela pretende ser um retrato verídico de como a prática se desenvolve em direção a determinado propósito. É comum, entretanto, que as pessoas fiquem incertas sobre a possibilidade de afirmarem que uma interpretação é correta e a outra não. Essa postura pode muitas vezes ser contraditória: um advogado pretende ter a melhor tese sobre o caso que defende, mas, ao ser confrontado fora do tribunal, pode admitir que outras teses são tão boas quanto a sua. O ceticismo sobre $o$ valor, que permite afirmar essa indeterminação, será necessariamente interno à prática

\footnotetext{
${ }^{129}$ Tradução livre de "We find it natural to report our conclusions, in each and every genre of interpretation, in the language of intention or purpose. We speak of the meaning or significance of a passage in a poem or play, of the point of a clause in a particular statute, of the motives that produced a particular dream, of the ambitions or understandings that shaped an event or an age."
} 
interpretativa: o advogado que admite ser impossível julgar qual a melhor tese para o caso concreto precisa defender uma interpretação do próprio caso que lhe permita afirmar isso.

Assim, em cada caso, quando oferecemos a interpretação de alguma coisa, nós afirmamos e somos entendidos como afirmando o que consideramos ser a verdade sobre algum assunto. Como a citação acima deixa claro, nós não tratamos essas práticas interpretativas como exercícios sem propósito: nós assumimos que algo de valor é e deve ser servido pela formulação, apresentação e defesa de opiniões sobre o que é interpretado sobre, para usar os exemplos de Dworkin, o escopo do dispositivo constitucional de que todos são iguais perante a lei, ou a história sexual de Lady Macbeth na peça de William Shakespeare. Nós aceitamos uma responsabilidade enquanto intérpretes de promover esse valor.

Quando interpretamos qualquer objeto ou evento particular, estamos também interpretando a prática de interpretação do gênero ao qual consideramos ter aderido: nós interpretamos esse gênero atribuindo a ele o que consideramos ser o seu propósito mais adequado - o valor que ele de fato provê e que ele deve prover (DWORKIN, 2011, p. 131).

A interpretação é, portanto, sempre interpretativa, não havendo um ponto fora dela a partir do qual possamos julgar seu sucesso - afinal, a prática anterior na qual nos baseamos também foi uma prática de interpretação. A teoria do valor está diretamente ligada à prática interpretativa e é determinante na elaboração de uma teoria da interpretação, que será, portanto, uma teoria do valor da interpretação:

Uma teoria da interpretação bem-sucedida deve atingir um equilíbrio tênue. Ele deve levar em conta o sentido e a possibilidade de verdade na interpretação, mas também deve levar em conta a inefabilidade dessa verdade e os familiares e irresolvíveis conflitos de opinião sobre onde ela está. Nem a simplicidade nem o ceticismo servirão. [...] Interpretação é um fenômeno social. Nós podemos interpretar como interpretamos apenas porque existem práticas ou tradições de interpretação às quais nós podemos aderir. (Ibid., p. 130) ${ }^{130}$.

Dworkin defende que é possível encontrar a verdade na prática interpretativa de maneira análoga à forma pela qual se formula juízos científicos verdadeiros. Não faz sentido diferenciar atribuir duas caracterizações diversas aos juízos interpretativos e

\footnotetext{
${ }^{130}$ Tradução livre de "A successful theory of interpretation must achieve a tenuous balance. It must account for the sense and possibility of truth in interpretation, but it must also account for the ineffability of that truth and the familiar, irresolvable clash of opinions about where it lies. Neither skepticism nor simplicity will do. [...] Interpretation is a social phenomenon. We can interpret as we do only because there are practices or traditions of interpretation we can join."
} 
científicos: aqueles poderiam ser apenas "mais ou menos razoáveis", mas apenas estes poderiam ser "verdadeiros". A verdade, na ciência ou na interpretação, significa um "sucesso único", e qualquer termo alternativo que adotássemos para os juízos interpretativos teria que significar exatamente isso para se adequar ao que pensamos.

Para explicar a diferença entre a ciência e a interpretação, Dworkin recorre à distinção entre objetivo intrínseco e objetivos justificadores. O objetivo intrínseco da ciência é encontrar a verdade sobre algo; os objetivos justificadores, por outro lado, são os mais diversos, sendo em geral práticos, mas nem sempre.

Ainda que os objetivos justificadores tenham um papel fundamental na ciência, não é, de nenhuma maneira, possível confundi-los com o objetivo intrínseco. Aqueles primeiros objetivos não compõem uma avaliação de quão bem-sucedida foi a procura da verdade. Em outras palavras, na ciência, objetivos justificadores não têm nada a ver com a verdade.

A interpretação traz uma diferença radical em relação à ciência entendida dessa maneira, pois, naquela, o objetivo justificador está no centro da experiência bem sucedida. A teoria valorativa da interpretação sustenta que os parâmetros para o sucesso da interpretação em determinado gênero (e, como Dworkin enfatiza, a interpretação só existe em gêneros, e não em geral) depende do que consideramos ser o melhor entendimento do propósito, ou da questão central (point) daquele gênero. Na atividade interpretativa, portanto, o valor intrínseco e os valores justificadores estão integrados, o que não ocorre na ciência.

Para entender a relevância dessa distinção para a teoria da unidade do valor, é preciso entender a afirmação de Dworkin de que a diferença entre esses dois grandes mundos da ciência e da interpretação equipara-se a e explica várias das diferenças entre a ciência e a própria moralidade:

Ao contrário de afirmações científicas, proposições interpretativas não podem simplesmente serem verdadeiras: elas podem ser verdade apenas em virtude de uma interpretação justificadora que se apoia num complexo de valores, nenhum dos quais pode também ser simplesmente verdade (DWORKIN, 2011, p. 153-4, grifos acrescentados). ${ }^{131}$

\footnotetext{
${ }^{131}$ Tradução livre de "Unlike scientific claims, interpretive propositions cannot be barely true: they can be true only in virtue of an interpretive justification that draws on a complex of values, none of which can be barely true either".
} 
Nesse trecho, fica clara a ideia, que já havia sido afirmada nos primeiros capítulos de Justice for Hedgehogs, de que a integração da moralidade é a única maneira possível de formular alegações morais verdadeiras.

Isso porque não podemos assegurar que nossas concepções de diferentes valores sejam persuasivas a menos que tais concepções se entrelacem, pois a estrutura dos nossos desacordos baseia-se na interpretação diversa das práticas que compartilhamos - nós sustentamos teorias diferentes sobre quais valores melhor justificam o que aceitamos como central ou paradigmático para uma prática. Sendo assim, conceitos interpretativos devem ser integrados uns com os outros, o que faz com que a interpretação, como já afirmado acima, seja a chave para a teoria da integração do valor.

Isso significa que não é possível dissociar a filosofia política de Dworkin de sua “epistemologia integrada” (DWORKIN, 2011, p. 82-6). A realização consciente do empreendimento interpretativo, como empreendimento que tem em vista a verdade dos juízos morais, exige a adoção de posições políticas coerentes que decorram das concepções adotadas e, assim, exclui a incerteza e a contradição. Em outras palavras, ela atende à ideia de "política coerciva" que nos nega o "luxo do ceticismo sobre o valor" (DWORKIN, 2011, p. 8): o espaço político nos exige opiniões que consideramos corretas. ${ }^{132}$

Uma vez elaborada essa teoria do valor na interpretação, Dworkin se preocupa em fazer uma abordagem dos diferentes tipos de interpretação e dos diferentes conceitos que podem ser interpretados. A interpretação pode ser colaborativa (a interpretação conversacional é o exemplo clássico aqui, trata-se daquele tipo de empreendimento interpretativo no qual o intérprete quer colaborar com o autor, e portanto, eles devem pensar estar compartilhando uma visão comum sobre o propósito da prática), explanatória (o intérprete não tem nenhum tipo de parceria com o interpretando - não compartilha com ele uma visão sobre o propósito da prática - e busca apenas fazer uma adscrição dos valores que operam em vários níveis da prática) ou conceitual ${ }^{133}$ (DWORKIN, 2011, p. 134-139).

A interpretação conceitual é a interpretação filosófica por excelência, e o raciocínio moral deve ser entendido como uma forma desse tipo de interpretação. Nela, a

\footnotetext{
132 “(...) it is our politics, more than any other aspect of our lives, that denies us the luxury of skepticism about value. Politics is coercive: we cannot stand up to our responsibility as governors or citizens unless we suppose that the moral and other principles on which we act or vote are objectively true" (DWORKIN, 2011, p. 8).

${ }^{133}$ Importante notar que tais distinções entre os diversos tipos de interpretação não devem ser exageradas. $\mathrm{O}$ critério para relacionar diferentes interpretações é, ele mesmo, interpretativo.
} 
distinção entre o autor e o intérprete some, pois ambos criam juntos o que é interpretado. Trata-se de um empreendimento no qual o desacordo é constante, pois atribuímos diferentes significados às palavras que expressam conceitos morais. Para entender então como é possível haver um desacordo genuíno nesse tipo de empreendimento, é preciso entender o que está sendo compartilhado na prática - a base a partir da qual pode haver uma discordância verdadeira (DWORKIN, 2011, p. 157-160).

Esse entendimento exige uma diferenciação entre os tipos de conceitos que compartilhamos. Eles podem ser criteriais, se compartilhamos os mesmos critérios para identificar diferentes instâncias do conceito, ou de tipos naturais, se se referem a coisas que têm uma identidade fixa na natureza.

O conceito que está em jogo na interpretação conceitual não é, entretanto, nenhum desses, e sim, o conceito interpretativo, cujo compartilhamento é possível "não porque nós concordamos em sua aplicação uma vez que concordamos em todos os outros fatos pertinentes, mas porque manifestamos um entendimento de que sua aplicação correta é fixada pela melhor interpretação da prática no qual figura" (DWORKIN, 2011, p. 160, grifos acrescentados) ${ }^{134}$.

O conceito interpretativo é, portanto, o conceito que figura nas práticas em que há grandes desacordos - podemos perceber que ele é um conceito compartilhado justamente pelo fato de haver desacordos que permitem entendê-lo como um esforço constante de chegar à melhor interpretação da prática, aquela que melhor aborde o seu propósito.

\footnotetext{
${ }^{134}$ Tradução livre de "(...) not because we agree in their application once all other pertinent facts are agreed upon, but rather by manifesting an understanding that their correct application is fixed by the best interpretation of the practices in which they figure".
} 


\section{CONCLUSÕES E AGENDA}

O caminho percorrido até aqui revelou que o interpretativismo é um método sólido e que apresenta sério desafios às teorias do direito puramente descritivas. A intenção da dissertação foi expor esse método e testá-lo frente a algumas críticas.

No primeiro capítulo, vimos como o positivismo de Herbert Hart rompe com a tradiução anterior e deixa um importante legado para a teoria do direito que o sucedeu, ao construir uma teoria que pretendeu ter abarcado a normatividade da prática jurídica - sua capacidade de fornecer razões para ação. A noção chave nesta teoria, e que será considerada crucial por toda a teoria do direito posterior, é a ideia de ponto de vista interno. Vimos que, ao trabalhar com essa ideia, Hart já havia estabelecido algumas das sementes interpretativistas que seriam cultivadas por Dworkin.

O segundo capítulo nos mostra o interpretativismo florescendo em toda a sua complexidade na obra de Dworkin. Vimos que suas principais ideias derivaram da necessidade de realizar uma teoria da controvérsia na prática jurídica, algo que havia sido largamente ignorado pela teoria do direito anteriore, e que tais ideias, antes de serem teses de filosofia da linguagem, possuem uma força política e crítica para entender a prática jurídica.

Neste capítulo também, tomamos contato com a crítica do positivista que deseja manter o quanto possível um resquício de descritivismo na teoria do direito. Ele aceita que a prática é normativa e moral, que ela influencia na maneira como seus participantes se comportam e raciocinam. No entanto, ele pensa que pode fornecer uma abordagem de tal prática de maneira a não se comprometer com as difíceis questões de moralidade política que ela coloca.

O terceiro capítulo mostrou a extensão do erro do positivista: ele deseja fazer uma teoria puramente descritiva sem qualquer evidência empírica e, assim, vemos que sua abordagem é ou uma sociologia manca ou uma teoria conceitual de pouca utilidade. Esse capítulo mostrou também toda a abrangência do projeto interpretativista do direito, que dá à prática de interpretação um lugar ao lado das ciências no domínio do conhecimento humano.

Chegando ao fim deste percurso, e considerando a ideia de que uma dissertação de mestrado serve, sobretudo, para "abrir horizontes", penso ser necessária um breve discussão sobre as inúmeras questões que podem ser levantadas a partir do método interpretativo proposto por Dworkin. 
Há questões filosóficas complexas, como a possibilidade de conhecimento objetivo na moral e a viabilidade de se integrar a moral à ética. Mas, como essa dissertação é voltada à teoria do direito e seus métodos, discuto abaixo duas questões de um nível menor de abstração (mas talvez maior de heterodoxia). A pretensão é tão somente abrir possíveis agendas de pesquisa a partir de alguns insights que o interpretativismo pode nos fornecer.

\section{Levando o interpretativismo a sério: uma agenda de pesquisas}

\subsection{Interpretação, instituições e sociologia jurídica}

Um desafio frequente que se coloca à teoria de Dworkin é um suposto e nefasto descolamento do direito da realidade das práticas institucionais, descolamento este que decorreria do método proposto pelo interpretativismo para a teoria jurídica.

Para colocar as bases dessa discussão, é interessante retomar o debate em torno da controversa afirmação de Hart de que o Conceito de Direito poderia ser considerado também um "ensaio de sociologia descritiva” (HART, 1997, p. vi). Segundo Nicola Lacey, biógrafa de Hart, a elaboração final deste autor sobre essa questão seria de que o Conceito de Direito teria pretendido oferecer uma elaboração de conceitos normativos necessários para a pesquisa empírica ${ }^{135}$. (LACEY, 2006, p. 949)

Ela aponta, no entanto, que Hart teria tido sérias limitações em sua abordagem. Por um lado, ele produziu uma teoria comprometida com a dimensão do fato social, o que significa que ela refletia alguns aspectos específicos da institucionalização do direito, comprometendo assim sua universalidade. Por outro lado, para atender justamente à pretensão de universalidade, ele falhou em fazer um paradigma mais rico da forma institucional do direito. (LACEY, 2006, p. 957-8)

Resenhando o trabalho de Lacey, Schauer é mais caridoso com a abordagem institucional de Hart, e afirma que justamente essa abordagem teria sido a grande contribuição do Conceito de Direito. O debate levado adiante com Dworkin, voltado principalmente para o momento da adjudicação - algo que Hart não teria pretendido abordar - teria distorcido e escondido essa contribuição, essencial para entender as

\footnotetext{
${ }^{135}$ Esse tipo de relação entre a teoria do direito e a pesquisa empírica, ou seja, com a teoria oferecendo conceitos ao pesquisador (e, reversamente, a pesquisa fornecendo correções à teoria) parece ser o único tipo de relação possível entre teoria e pesquisa considerado por Galligan (2010), que pretendeu fazer um levantamento das possíveis interações entre os dois campos.
} 
instituições e operações do direito, especialmente no que descreve este como um sistema de união de regras primárias e secundárias que culminam na regra de reconhecimento. (SCHAUER, 2006, p. 877-879)

O trabalho de Schauer mereceu resposta de Dworkin, em um artigo no qual este elaborou pela primeira vez a distinção entre os conceitos doutrinário e sociológico, como maneira de esclarecer porque, ao contrário do afirmado por Schauer, seria impossível distinguir teorias sobre a natureza do Direito (algo que, segundo Schauer, Hart teria pretendido fazer) e teorias sobre como os juízes decidem os casos (algo que Hart não teria pretendido fazer). (DWORKIN, 2006a, p. 97)

O ponto da crítica de Dworkin é esclarecer que Hart ofereceu respostas interconectadas tanto a questões doutrinárias quanto a questões sociológicas, mas, ao contrário do que sugere Schauer, a resposta às primeiras é mais interessante que às segundas. Isso porque a contribuição distintiva de Hart não teria sido mostrar que o direito tem uma organização sistemática - algo que outros teóricos (como Hans Kelsen) já haviam feito - mas sim o argumento de que, nos sistemas jurídicos paradigmáticos, a regra de reconhecimento tem força somente por meio de uma convenção, e pode ser identificada somente por meio de uma prática social (DWORKIN, 2006a, p. 100). Esse é, afirma Dworkin, um argumento caracteristicamente doutrinário.

Schauer, em sua tréplica, não se preocupa tanto em debater a interpretação de Hart, mas foca-se na surpreendente afirmação de Dworkin de que a questão sociológica não teria "nem muito interesse prático nem filosófico" (Dworkin, 2006a, p. 98). Schauer argumenta que o conceito doutrinário teria, na verdade, bases sociológicas. Por exemplo, mesmo que a promulgação de uma lei pelo Parlamento não seja nem uma condição suficiente nem uma condição necessária para a verdade de uma proposição jurídica, seria equivocado não considerar essa promulgação como, pelo menos, algo relevante para a questão de se uma proposição normativa é ou não jurídica. Assim, parece evidente que o comportamento da instituição traz, sim, implicações relevantes para a questão doutrinária. Mais ainda, é o fato de a instituição ser de direito que leva a essa relevância, sendo assim necessário identificar essa instituição como sendo ou não jurídica - justamente a questão sociológica - para abordar a questão doutrinária.

Colocada dessa maneira, a objeção parece ser um argumento convincente contra a "primazia" do conceito doutrinário na teoria do direito, considerado $o$ conceito interpretativo a ser analisado, em prejuízo do conceito sociológico. Parece revelar, 
ademais, que o interpretativismo proposto por Dworkin peca pelo normativismo desconectado das práticas institucionais.

Devemos considerar, entretanto, que, assim como o conceito criterial pode ser considerado um conceito interpretativo, também o conceito sociológico pode vir a se tornar doutrinário nos casos em que, como afirmado por Schauer, o comportamento da instituição traz implicações relevantes para a questão doutrinária. O próprio Dworkin cita um exemplo: em um país pós-revolucionário, a questão de se as instituições do regime anterior constituíam um sistema jurídico é uma questão importante e moralmente relevante no momento em que os oficiais do regime anterior são submetidos a julgamento, pois a justiça da punição depende do esclarecimento daquela questão (Dworkin, 2006a, p. 99, nota 12). Nesse caso, o problema da identificação das instituições como sendo jurídicas, questão tipicamente sociológica, deve ser vista como uma questão doutrinária.

Essa discussão não tem fins meramente classificatórios de questões e conceitos. Ela é relevante para esclarecer a posição das análises de instituições no interpretativismo proposto por Dworkin. É relevante também para entender como a própria classificação dos conceitos é um empreendimento de interpretação conceitual e, assim, não deve ser entendida como uma proposta de exclusão a priori de qualquer tema do âmbito da teoria do direito. Argumentos como os de Schauer ${ }^{136}$ parecem revelar uma má compreensão desse ponto, ao afirmarem uma contraposição fixa entre conceito doutrinário e sociológico.

Tais conceitos, ao contrário, aparecem profundamente imbricados nas atividades da sociologia jurídica, que tem como uma de suas tarefas principais a identificação dos paradigmas da prática jurídica, exatamente no sentido formulado por Dworkin em $O$ Império do Direito. Devemos lembrar que os paradigmas são históricos e qualquer definição sobre eles é contestável, ainda que, para contarem como verdadeiros paradigmas, seja necessário não haver ampla discordância a seu respeito.

A sociologia jurídica é, em larga medida, o exercício de identificar os paradigmas jurídicos de cada época, ou quais paradigmas podem vir a se formar a partir das mudanças - sociais, econômicas ou políticas - que estejam se configurando nas práticas ${ }^{137}$. O sociólogo do direito pode revelar ainda a existência de crises tão profundas na prática que impedem a caracterização de um único paradigma, mostrando que se atravessa uma época

\footnotetext{
${ }^{136}$ Que, ademais, apoia-se em uma tradição maior, cujo maior expoente é Neil MacCormick, com sua teoria institucional do direito. Ver MACCORMICK, $2008 \mathrm{~b}$.

${ }^{137}$ Nesse sentido, um exercício que tenta identificar possíveis cenários de organização do direito em nível global a partir da crise econômica mais recente (FARIA, 2011) é um exercício de projeção de paradigmas.
} 
de transição. Acredito que é assim que deve ser entendida, por exemplo, a caracterização de crises da prática jurídica que fazem com que esta praticamente se rompa, mostrando o profundo grau de desacordo que se instaurou na prática (FARIA, 1999, p. 11-149).

Esses diagnósticos fornecidos pela sociologia, mais que relevantes para um entendimento geral do que é o direito, são necessários para abordagens e usos do conceito doutrinário do direito. Afinal, como Dworkin nos mostra, os paradigmas "ancoram" a interpretação. Que não exista um único paradigma que possa ser identificado em uma prática jurídica em crise pode nos mostrar que a interpretação perdeu suas âncoras e, assim, pode ser base para afirmamos que a prática jurídica já não se direciona a um valor que deve ser plasmado pelo conceito doutrinário, ela não possui uma intencionalidade clara. Nesses casos, o ceticismo pode ser a única interpretação disponível.

\subsection{Conceitos doutrinários, dogmática jurídica e autoconsciência da interpretação}

Se a identificação dos paradigmas é tarefa da sociologia do direito, a identificação de possíveis abordagens dos conceitos doutrinários é o ofício da dogmática jurídica.

O conceito de dogmática jurídica é controverso e passou por transformações históricas, que em certa medida acompanharam as transformações da própria filosofia e da teoria do direito. Assim, se a dogmática surgiu como técnica, quase um conhecimento "artesanal", ela adquiriu, com o tempo e a afirmação do campo das ciências sociais, um caráter científico, passando a se localizar no interior da "ciência do direito" (BATALHA, 2010, p. 129-139).

O interpretativismo deixa claro, entretanto, que o direito não é um conhecimento que opera em termos científicos. Ao contrário, ele tem sua própria metodologia, que é a interpretação. Essa metodologia afirma que todo empreendimento teórico no direito é um conhecimento necessariamente avaliativo.

Isso significa dizer que o pesquisador do direito, quando faz uma análise pretensamente descritiva que proponha respostas para a questão doutrinária, está, na realidade, oferecendo uma proposta de interpretação para a prática jurídica que envolve a avaliação moral de seu propósito ${ }^{138}$. O mesmo vale para o "doutrinador": mesmo que ele

\footnotetext{
${ }^{138}$ Essa observação é particularmente relevante para as pesquisas de jurisprudência que pretendem fornecer uma abordagem geral sobre "o que os tribunais falam" ou "como eles se comportam" em relação a determinado tema ou questão.
} 
não se veja avaliando os propósitos do campo do direito por ele teorizado, sua teoria fornece proposições jurídicas (ainda que em níveis mais abstratos do que as proposições da prática) e, assim, está comprometida com determinada visão sobre os fundamentos do direito $^{139}$.

Desse modo, se compreendermos a atividade dos pesquisadores e doutrinadores como uma prática interpretativa no sentido colocado por Dworkin, torna-se possível revelar as bases justificadoras do direito que são adotadas naquela atividade - que, assim, vê-se excluída da zona de conforto da mera descrição e do ceticismo moral.

Para isso, é preciso ressignificar o conceito de dogmática jurídica. MACEDO JR. (2012, p. 182, nota 536) afirma corretamente ${ }^{140}$ que

muitas vezes o conceito dogmático de direito, apresentado nos livros de 'doutrina jurídica', mais se aproxima do conceito sociológico, definido por Dworkin, na medida em que acolhe o princípio da legalidade e o fato da positivação como o ponto de partida dogmático como sua concepção do direito. Daí o dogma do princípio da legalidade, normalmente fixado com base em uma concepção positivista do direito.

No entanto, ainda que a maneira como a doutrina se coloca e a maneira como ela é vista pareça aproximá-la do direito em seu sentido sociológico, sendo que os doutrinadores frequentemente se veem como estando comprometidos apenas com um conceito descritivo de direito, o interpretativismo pode nos mostrar que não é esta a real posição metodológica que eles ocupam.

A atribuição de um caráter sociológico ao conceito dogmático de direito assemelha-se à confusão conceitual que examinamos na teoria de Joseph Raz. O doutrinador pretende usar esse conceito para descrever as características essenciais da prática específica à qual se volta seu estudo, no entanto, a menos que ele possua uma grande quantidade de evidência empírica que lhe permita dizer que sua abordagem é, realmente, uma descrição da prática, um relatório de tudo o que se alega, que se permite, que se proíbe e que se possibilita nessa prática $^{141}$, o que ele estará fornecendo é, na

\footnotetext{
${ }^{139}$ Nesse sentido, basta lembrar do exemplo invocado nessa dissertação para explicar os desacordos teóricos: um das proposições jurídicas que se discutiu foi extraída de um manual de direito constitucional.

${ }^{140}$ Ainda que o autor faça essa afirmação para negar que o conceito doutrinário de direito seja o conceito da doutrina, entendida no seu sentido ordinário. A posição adotada aqui é, como se verá, oposta a esta.

${ }^{141}$ E esse tipo de descrição pode ser realmente possível para o doutrinador ou para o pesquisador voltado a áreas específicas do direito. Tal posição não estava disponível para o próprio Raz, porque este pretendeu fornecer uma abordagem sociológica do direito como um todo, tarefa impossível de ser feita não só pela quantidade de dados que exige, mas pela incontornável vagueza do conceito sociológico de direito.
} 
verdade, uma abordagem doutrinária da área do direito e dos específicos institutos jurídicos que são objeto de seu estudo.

O que o interpretativismo parece propor, nesse contexto, é que a dogmática jurídica será sempre um trabalho necessariamente incontroverso e inacabado, pois a amplitude do desacordo na prática jurídica não permite uma exposição técnica e definitiva de todas as exigências do direito. Em uma sociedade na qual a prática jurídica seja ampla o suficiente para abarcar a população em geral, que passa a formular suas pretensões políticas na linguagem jurídica (como parece estar ocorrendo em boa parte das democracias contemporâneas), tal exposição não poderá ser fornecida nem mesmo como um instrumento de "estabilização" do direito, direcionado aos leigos. ${ }^{142}$ Pois estes também adotarão a atitude interpretativa de contestação, divergindo sobre o que o direito lhes permite e lhes concede.

Tudo isso parece apontar para uma necessidade de ressignificação da dogmática jurídica, como um instrumento que nos permite lidar com a controvérsia aceitando o caráter conflitivo e sempre incompleto da prática jurídica. $\mathrm{Na}$ feliz expressão de PÜSCHELL\&RODRIGUEZ (2012, p. 97), o trabalho do dogmático, então, passa a ser um "trabalho de Sísifo":

A dogmática nos dá meios para lidar com a incerteza, mas para afirmá-la e não para negá-la. O trabalho dogmático assemelha-se ao trabalho de Sísifo, mas com duas diferenças: a pedra que se deve carregar tem seu peso e forma alterados a cada passo; e a montanha que é preciso escalar está sempre mudando de lugar. ${ }^{143}$

\footnotetext{
${ }^{142}$ A noção de dogmática defendida por FERRAZ JR. envolve essa visão de certa maneira "cínica" da dogmática, que é apresentada como um instrumento de "viabilização possível" das pretensões jurídicas: "Em sociedades de alta complexidade, porém, esta congruência [entre mecanismos de controle expectativas sociais] tem de ser veiculada. E é aqui que aparece a função social da Dogmática Jurídica. Ela é, a nosso ver, uma instância instrumental de viabilização do Direito, na medida em que atua como veículo de alta abstração capaz de proporcionar uma congruência estável entre mecanismos de controle social, mesmo quando, aparentemente, eles não se afirmam. Neste sentido, ela viabiliza as condições do juridicamente possível." (FERRAZ JR., 1980, p. 116).

${ }^{143}$ Nesse sentido, v. também RODRIGUEZ (2012).
} 


\section{REFERÊNCIAS BIBLIOGRÁFICAS}

AFONSO DA SILVA, José. Curso de Direito Constitucional. São Paulo, Malheiros, 2012.

BATALHA, Carlos Eduardo Batalha. A filosofia jurídica como saber metaideológico: anotações a partir da função social da dogmática jurídica no enfoque de Tercio Sampaio Ferraz Jr. In: RODRIGUEZ, José Rodrigo / BATALHA, Carlos Eduardo Batalha / BARBOSA, Samuel Rodrigues (Org.). Nas fronteiras do formalismo: a função social da dogmática jurídica hoje. São Paulo: Saraiva, 2010. Pp. 129-156.

BIX, Brian. H.L.A. Hart and the Hermeneutic Turn in Legal Theory. In: Southern Methodist University Law Review, Vol. 52, 1999. Pp. 167-199.

. Some reflections on methodology of jurisprudence. In: Cáceres Nieto, Enrique / Flores, Imer B. / Saldaña, Javier Y Villanueva, Enrique (Org.). Problemas Contemporaneos de la filosofia de derecho. Universidad Autónoma de México, 2005. Pp. 77-96. Disponível em http://www.bibliojuridica.org/libros/libro.htm?1=1650.

. Ideals, practices and concepts in legal theory. In: $1^{\text {st }}$ Conference on Philosophy and Law: Neutrality and Theory of Law. Girona, Maio de 2010.

Bix, Brian, Will Versus Reason: Truth in Natural Law, Positive Law, and Legal Theory (July 21, 2008). TRUTH: STUDIES OF A ROBUST PRESENCE, Kurt Pritzl, ed., Catholic University of American Press, 2010. Available at SSRN: $\underline{\text { http://ssrn.com/abstract }=1166082}$

CHUEIRI, Vera Karam; SAMPAIO, J. M. A. S. Como levar o Supremo Tribunal Federal a sério: sobre a suspensão de tutela antecipada n 91. Rev. DIREITO GV, vol .5, no.1, São Paulo, jan./jun. 2009.

CLAREY, Cristopher. Dreaming of an end to soccer's nightmare. New York Times, 12 de março de 2010. Disponível em: http://www.nytimes.com/2010/03/13/sports/soccer/13iht-ARENA.html?_r=1\&).

COHEN, Marshall (Org.). Ronald Dworkin and Contemporary Jurisprudence. London: Duckworth, 1984.

COLEMAN, Jules. The practice of principle: in defense of a pragmatist approach to legal theory. Oxford: Oxford University, 2001. 
COLEMAN, Jules. (Org.) The Hart's Postscript: essays on the Postscript of The Concept of Law. Oxford University Press, 2001b.

COLEMAN, Jules. Methodology. In: COLEMAN, Jules L.; SHAPIRO, Scott (Eds.). The Oxford handbook of jurisprudence and philosophy of law. Oxford: Oxford University Press, 2002. p. 311-351.

COLEMAN, Jules; SIMCHEN, Ori. Law. Legal Theory, Oxford, v. 9, 2003.

DALL'AGNOL, Darlei. O igualitarismo liberal de Dworkin. Kriterion v.46 n.111 Belo Horizonte jan./jun. 2005.

DICKSON, Julie. Evaluation and legal theory. Oxford: Portland Oregon - Hart Publishing, 2001.

DICKSON, Julie. Methodology in Jurisprudence: a critical survey. In: Oxford Review for Legal Theory $n^{\circ}$ 10(3), 2004. Pp. 117-156

DWORKIN, Ronald. Social sciences and constitutional rights - the consequences of uncertainty. In: Journal of Law \& Education, vol. 6., $n^{\circ}$ 1, 1977. Pp. 3-12.

DWORKIN, Ronald. De que maneira o direito se assemelha à literatura. In: DWORKIN, Ronald. Uma questão de princípio. Tradução de Luís Carlos Borges. 2. ed. São Paulo: Martins Fontes, 2005. p. 217-250.

DWORKIN, Ronald. The Philosophy of Law (Oxford Readings in Philosophy). Oxford University Press, 1977.

DWORKIN, Ronald. Taking Rights Seriously. Harvard University Press, 1978.

DWORKIN, Ronald. A Matter of Principle. Harvard University Press, 1985.

DWORKIN, Ronald. Law’s Empire. Belknap Press of Harvard University Press, 1986.

DWORKIN, Ronald. Life's Dominion: an argument about abortion, euthanasia, and individual freedom. New York: Vintage Books, 1994.

DWORKIN, Ronald. Objectivity and Truth: you'd better believe it. In: Philosophy and Public Affairs, 1996. Pp. 87-139.

DWORKIN, Ronald. Hart and the concepts of law. In: Harvard Law Review Forum, 2006a. Pp. 95-104. 
DWORKIN, Ronald. Justice in Robes. Cambridge: Belknap Press of Harvard University Press, 2006b.

DWORKIN, Ronald. Justice for Hedgehogs. Cambridge: Belknap Press of Harvard University Press, 2011.

EDVINSSON, Reidar. The quest for the description of the Law. Berlim: Springer-Verlag, 2009.

ENDICOTT, Timothy. Herbert Hart and the Semantic Sting. Legal Theory, Oxford, v. 4, p. 283-300, 1998.

ENOCH, David. Reason-Giving and the law. In GREEN, L.; LEITER, B. (Ed.) Oxford Studies in Philosophy of Law: Volume 1. Oxford, 2005.

FARIA, José Eduardo. O direito na economia globalizada. São Paulo: Malheiros, 1999.

FARIA, José Eduardo O estado e o direito depois da crise. São Paulo: Saraiva, 2011.

FARIA, José Eduardo CAMPILONGO, Celso Fernandes. A Sociologia Jurídica no Brasil. Porto Alegre: Sergio Antonio Fabris Editor, 1991.

FARREL, Ian P.. H. L.A. Hart and the Methodology of Jurisprudence: a review of 'A life of H.L.A. Hart: the nightmare and the noble dream' by Nicola Lacey'. In: Texas Law Review, Vol. 86, 2006. Pp. 983-1011.

FERRAZ JR., Tercio Sampaio. Introdução ao Estudo do Direito. São Paulo: Atlas, 2003.

FERRAZ JR., Função social da dogmática jurídica. São Paulo: Editora Revista dos Tribunais, 1980.

FINNIS, John. Natural Law and natural rights. Oxford University Press, 1980.

FINNIS, John. On Hart's ways: law as reason and as fact. American Journal of

Jurisprudence, Notre Dame, v. 52, p. 25-53, 2007.

FURQUIM, Lilian de Toni. O liberalismo abrangente de Ronald Dworkin [en línea]. São Paulo : Faculdade de Filosofia, Letras e Ciências Humanas, Universidad de São Paulo, 2010. Tesis Doctoral en Ciência Política. [citado 2013-01-21]. Disponible en Internet: <http://www.teses.usp.br/teses/disponiveis/8/8131/tde-02122010$111403 />$. 
GALLIE, Walter Bryce. Essentially contested concepts. In: Proceedings of Aristotelian Society, New Series, Vol. 56, 1956-1956. Pp. 167-198.

GALLIGAN, D.J. Legal theory and empirical research. In: CANE, Peter / KRITZER, Herbert. The Oxford Handbook of Empirical Legal Research. New York: Oxford University, 2010. Pp. 976-1001.

GREENBERG, Mark. How facts make Law. In: HERSHOVITZ, Scott (Org.). Exploring Law's Empire: the Jurisprudence of Ronald Dworkin. Oxford University Press, 2006. 225-264.

GREENBERG, Mark. Hartian Positivism and normative facts: how facts make Law II. In: HERSHOVITZ, Scott (Org.). Exploring Law's Empire: the Jurisprudence of Ronald Dworkin. Oxford University Press, 2006. 225-264.

GUEST, Stephen. Ronald Dworkin. Stanford: Stanford University Press, 1991.

GUEST, Stephen. Two strands in Hart's theory of Law: a comment on the Postscript to Hart's The Concept of Law. In: Positivism Today. Dartmouth Publishing Group, 1996. Pp. 265-311.

Guest, Stephen (2009). How to criticize Ronald Dworkin's theory of law. Analysis 69 (2):352-364. Disponível em: <http://analysis.oxfordjournals.org/content/69/2/352>

HACKER, P. M. S.. Definition in Jurisprudence. In: Philosophical Quarterly n 19 (77), 1969. Pp. 343-347.

HALPIN, Andrew. The methodology of jurisprudence: thirty years off the point. Canadian Journal of Law and Jurisprudence, Ontario, v. 19, p. 67-105, 2006. Disponível em: <http://papers.ssrn.com/sol3/papers.cfm?abstract_id=880803>. Acesso em: 20 ago. 2012.

HART, Herbert L. A. Essays in Jurisprudence and Philosophy. Oxford University Press, 1984.

HART, Herbert L. The Concept of Law. $2^{\text {nd }}$ Ed. Oxford University Press, 1997.

HART, Herbert L. O Conceito de direito. 2. Ed. Lisboa: Calouste Gulbekian, 2005;

IKAWA, Daniela. Hart, Dworkin e discricionariedade. Lua Nova, n.61, São Paulo, 2004 
JACKSON, Frank. From Metaphysics to Ethics: A Defence of Conceptual Analysis. Oxford University Press, 1998.

LACEY, Nicola. A life of H. L. A. Hart: the nightmare and the noble dream. Oxford University Press, 2006.

LACEY, Nicola. Analytical Jurisprudence versus Descriptive Sociology Revisited. In: Texas Law Review, n. 84, 2006. Pp. 945-982.

LEITER, Brian. Beyond the Hart/Dworkin Debate: the methodology problem in Jurisprudence. In: Naturalizing Jurisprudence. Oxford University Press, 2007. Pp. 153-181.

MACCORMICK, Neil. Law as institutional fact. In: MACCORMICK, Neil / WEINBERGER, Ota. An institutional Theory of Law: new approaches to legal positivism. D. Reidel Publishing, 1986. Pp. 49-76.

MACCORMICK, Neil. H. L. A. Hart. - Jurists: Profiles in Legal Theory. $2^{\text {nd }}$ Edition. Stanford Law Books, 2008.

MACCORMICK, Neil. Institutions of Law: an essay in Legal Theory (Law, State, and Practical Reason). Oxford University Press, 2008b.

MACEDO JR., Do xadrez à cortesia: Ronald Dworkin e a teoria do direito contemporânea. Tese de livre-docência apresentada à Faculdade de Direito da Universidade de São Paulo, 2012.

MAIA, Marco. Respeitar o Legislativo é defender a democracia. Tendências e Debates Folha de São Paulo, 10 de dezembro de 2012.

MARMOR, Andrei. Legal positivism: still descriptive and morally neutral. USC Legal Studies Research Paper n. 5-16. Jul. 2005. Disponível em: $<$ http://papers.ssrn.com/sol3/papers.cfm?abstract_id=763844>. Acesso em: 20 ago. 2012.

MICHELON JR., Cláudio Fortunato. Aceitação e objetividade: uma comparação entre as teses de Hart e do positivismo precedente sobre a linguagem e o conhecimento do Direito. São Paulo: Revista dos Tribunais, 2004.

MOORE, Michael S. The interpretative turn in modern theory: a turn from the worse. Stanford Law Review, Stanford v. 41, p. 871-957, 1988-1989. 
NOBRE, Marcos. Apontamentos sobre a pesquisa em Direito no Brasil, Novos Estudos CEBRAP, n. 66, p.145-54, jul. 2003.

OBERDIEK, John; PATTERSON, Dennis. Moral evaluation and conceptual analysis in jurisprudential methodology. Current Legal Issues: Law and Philosophy, 2007. Disponível em: <http://papers.ssrn.com/sol3/papers.cfm?abstract_id=925628>.

PERRY, Stephen R.. Hart's methodological positivism. In: Cambridge Legal Theory $\mathrm{n}^{\circ} 4$, 1998. Pp. 427-467.

PERRY, Stephen R.. Interpretação e metodologia na teoria jurídica. In: MARMOR, Andrei. Direito e Interpretação: ensaios de Filosofia do Direito. São Paulo: Martins Fontes, 2000. Pp. 145-203.

PERRY, Stephen. Interpretation and methodology in legal theory. In: MARMOR, Andrei (Ed.). Law and interpretation. Oxford: Clarendon, 1995. p. 97-135.

PERRY, Stephen R.. Hart on Social Rules and the Foundations of Law: Liberating the Internal Point of View, Fordham Law Review, v. 75, 2006

PIRES, Álvaro Pena et alli. A pesquisa qualitativa. Enfoques epistemológicos e metodológicos. Petrópolis: Editora Vozes, 2008.

PUSCHELL, Flávia; RODRIGUEZ, José Rodrigo. Invejar Sísifo: a racionalidade jurídica entre sistema e problema. In MACHADO, Marta; PUSCHELL, Flávia; RODRIGUEZ, José Rodrigo (Orgs.) Dogmática é conflito. Uma visão crítica racionalidade juridical. São Paulo, Saraiva, 2012.

RAZ, Joseph. Ethics in the public domain: essays in the morality of law and politics. Oxford: Clarendon, 1995.

RAZ, Joseph. Two views of the nature of the Theory of Law: a partial comparison. In: Cambridge Legal Theory n 4, 1998. Pp. 249-282.

RAZ, Joseph. On reasons for action. In: Practical reason and norms. Oxford University Press, 2002. Pp. 15-48.

RAZ, Joseph. Can there be a theory of law?. In: GOLDING, Martin / EDMUNDSON, William. Blackwell guide to Philosophy of Law and Legal Theory, 2004. Disponível em http://ssrn.com/abstract=1010287. 
RAZ, Joseph. On the nature of Law. In: Between Authority and Interpretation: on the Theory of Law and Practical Reason. Oxford University Press, 2009. Pp. 91-125. RIPSTEIN, Arthur (Org.). Ronald Dworkin. Cambridge University Press, 2007.

RODRIGUEZ, José Rodrigo. Dogmática jurídica (verbete). In: NOBRE, Marcos (Org.). Curso Livre de Teoria Crítica. São Paulo: Papirus, 2008. Pp. 301-302.

RODRIGUEZ, José Rodrigo. Dogmática é conflito: a racionalidade jurídica entre sistema e problema. In MACHADO, Marta; PUSCHELL, Flávia; RODRIGUEZ, José Rodrigo (Orgs.) Dogmática é conflito. Uma visão crítica racionalidade juridical. São Paulo, Saraiva, 2012.

RODRIGUEZ, José Rodrigo. / BATALHA, Carlos Eduardo Batalha / BARBOSA, Samuel Rodrigues (Org.). Nas fronteiras do formalismo: a função social da dogmática jurídica hoje. São Paulo: Saraiva, 2010.

RODRIGUEZ-BLANCO, Veronica. “A Defence of Hart's Semantics as Non-Ambitious Conceptual Analysis". In: Legal Theory (2003).

RODRIGUEZ-BLANCO, Veronica. The Methodological Problem in Legal Theory: Descriptive and Normative Jurisprudence Revisited. In: Ratio Juris, vol. 19, n. 1, 2006, pp 26-54.

SCHAUER, Frederick. (Re)taking Hart. In: Harvard Law Review, vol. 119, 2006. Pp. 852883.

SCHAUER, Frederick. Institutions and the Concept of Law: a reply to Ronald Dworkin (with some help from Neil MacCormick). In: BANCKOWSKI, Zenon / DEL MAR, Maksymilian. Law as institutional normative order. Farnham: Ashgate Publishing, 2009. Pp. 35-44.

SHAPIRO, Scott. The Hart-Dworkin Debate: a short guide for the perplexed. In: RIPSTEIN, Arthur (Org,) Ronald Dworkin. Cambridge University Press, 2007. Pp. 22-55. Disponível em: 〈http://ssrn.com/abstract=968657〉. Acesso em: 20 ago. 2012.

SHAPIRO, Scott. Legality. Cambridge, USA: Harvard University Press, 2011.

Smith, D.A., 2009, Has Raz Drawn the Semantic Sting?, Law and Philosophy, vol 28, Springer Netherlands, The Netherlands, pp. 291-325. 
STAVROPOULOS, Nicos. 2001. "Hart's semantics". In: COLEMAN, Jules. The Hart's Postscript: essays on the Postscript of The Concept of Law. Oxford University Press, 2001. Pp. 59-99.

STAVROPOULOS, Nicos. Interpretivist Theories of Law. In: Stanford Encyclopaedia of Philosophy. Disponível em: http://plato.stanford.edu/entries/law-interpretivist/

WEBER, Max. Economia e sociedade. Tradução de Regis Barbosa e Karen Elsabe Barbosa. Revisão técnica de Gabriel Cohn. Brasília: Editora da UnB; São Paulo: Imprensa Oficial do Estado de São Paulo, 2004. v. 1.

WINCH, Peter, The Idea of a social science and its relation to philosophy. $8^{\mathrm{a}}$ impressão. Londres: Routledge, 1973.

WITTGENSTEIN, Ludwig. Philosophical investigations. 4th ed. Edited by P. M. S. Hacker and Joachim Schulte. Oxford: Wiley-Blackwell, 2009. 